LEONARDO DOMINGUEZ DIAS

MÉTODO DE INSTANCIAÇÃO DE UMA ARQUITETURA DE PROCESSOS APLICADO EM FÁBRICA DE SOFTWARE

São Paulo

2010 


\section{MÉTODO DE INSTANCIAÇÃO DE UMA ARQUITETURA DE PROCESSOS APLICADO EM FÁBRICA DE SOFTWARE}

Dissertação apresentada à Escola

Politécnica da Universidade de

São

Paulo para obtenção de título de

Mestre em Engenharia

Área de Concentração: Engenharia de Computação e Sistemas Digitais

Orientador: Prof. Doutor Jorge Luis Risco Becerra

São Paulo 
Este exemplar foi revisado e alterado em relação à versão original, sob responsabilidade única do autor e com a anuência de seu orientador.

São Paulo, de maio de 2010.

Assinatura do autor

Assinatura do orientador

FICHA CATALOGRÁFICA

Dias, Leonardo Dominguez

Método de instanciação de uma arquitetura de processos aplicado em fábrica de software / L.D. Dias. -- São Paulo, 2010. $114 \mathrm{p}$.

Dissertação (Mestrado) - Escola Politécnica da Universidade de São Paulo. Departamento de Engenharia de Computação e Sistemas Digitais.

1. Processo de software 2. Experimentos científicos 3. Qualidade de processo de software I. Universidade de São Paulo. Escola Politécnica. Departamento de Engenharia de Computa cão e Sistemas Digitais II. t. 


\section{DEDICATÓRIA}

Dedico este trabalho à minha família que sempre me apoiou com entusiasmo. 


\section{AGRADECIMENTOS}

Ao orientador e amigo Jorge Luis Risco Becerra, pela orientação e pelo constante estímulo transmitido durante todo o trabalho.

À amiga professora Gabriela Cabel Barbarán pelas discussões e experiência agregados aos experimentos.

Aos Amigos e a todos que colaboraram direta ou indiretamente, na execução deste trabalho. 
A essência do conhecimento é obtê-lo para aplicá-lo; não obtê-lo para confessar sua ignorância.

(Confúcio. Filósofo Chinês.) 


\section{RESUMO}

Atualmente são diversos os modelos de qualidade, internacionais e nacionais (CMMI, SPICE, MPS.BR), mas o número de empresas que os utilizam é ainda reduzido. Tal fato não é justificado pela falta de interesse das empresas, pois, além de aumentarem o controle e qualidade dos processos e produtos, esses modelos são importantes para 0 desenvolvimento e para a exportação de software. Um dos fatores que leva a baixa utilização dos modelos de qualidade é a falta de um método para instanciação destes modelos ao domínio de negócio específico de cada empresa. Método que possa ser utilizado para diferentes modelos de qualidade desde que exista uma arquitetura de referência baseada neste modelo. Este trabalho apresenta um método de instanciação de processos que a partir de uma arquitetura de referência baseada em um modelo de qualidade e das características da empresa geram processos de uma fábrica de software. O método proposto será aplicado experimentalmente em duas empresas reais a fim de se coletar dados sobre a utilização do método em situações reais. As aplicações do método de instanciação nas empresas reais seguirão um roteiro de execução de experimentos de engenharia de software experimental. 


\begin{abstract}
Currently there are several quality models, international and national (CMMI, SPICE, MPS.BR), but the number of companies that use them is still low. This fact is not justified by the lack of interest of companies, because, in addition to increasing control and quality of products and processes, these models are important to development and to export software. One of the factors that leads to low use of quality models is the lack of a method for instantiation of these models to the of company's specific business domain. A method that can be used to different quality models since there is a reference architecture based on these models. This paper presents a method to instantiate processes to a software factory from characteristics of business and from a reference architecture which is based on a quality model. The proposed method will be applied experimentally on two real companies in order to collect data on the use of the method. The real applications of the instantiation method in real companies follow a roadmap for execution of software engineering experiments.
\end{abstract}




\section{LISTA DE ILUSTRAÇÕES}

Gráfico 1 - Gráfico da evolução anula do faturamento das empresas de software e serviços brasileiras no período de 2004 a 2008. Fonte: Adaptado de ABES (2008)

Gráfico 2 - Gráfico sobre o grau de importância das barreiras tecnológicas, organizacionais e produticas de exportação segundo freqüência de marcação. Fonte: Adaptado de SOFTEX UNICAMP (2005)

Gráfico 3 - A pesquisa deste trabalho no quadrante de Pasteur. 26 


\section{LISTA DE FIGURAS}

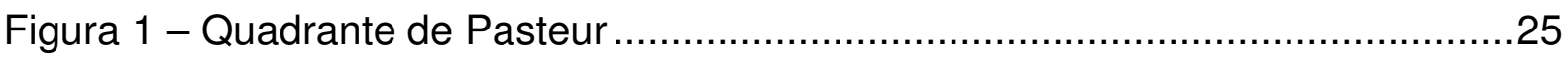

Figura 2 - Visões da fábrica de software integrada ...............................................35

Figura 3 - modelo de referência PROMOTER (adaptador de DERNIAME, KABA, WASTELL, 1999)

Figura 4 - etapas do modelo conceitual do ciclo de vida de processos (fonte:

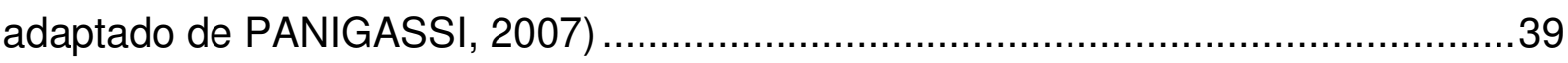

Figura 5 - Exemplo de um objeto processo …….............................................

Figura 6 - Modelos da visão processo da Fábrica de software que compõem a arquitetura de processos.

Figura 7 - Conceitos fundamentais da arquitetura de processos (adaptado

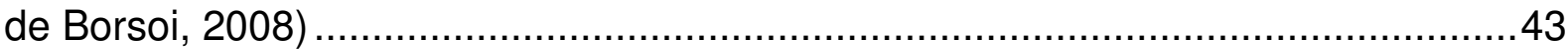

Figura 8 - Níveis de abstração entre arquiteturas de processo ................................45

Figura 9 - llustração da instanciação de um objeto processo...................................47

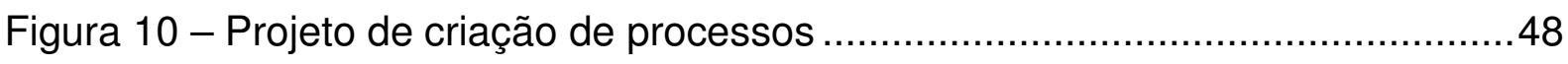

Figura 11 - Instanciação de arquitetura de processos .......................................50

Figura 12 - Modelo conceitual do método de instanciação da instanciação do

Tipo I

Figura 13 - Modelo conceitual do método de instanciação da instanciação do

Tipo II

Figura 14 -Detalhamento da 'Especificação dos processos'

Figura 15 - Diagrama descritivo da atividade (fonte: Adaptado de Borsoi, 2008) 59

Figura 16 - Diagrama descritivo do papel (fonte: Adaptado de Borsoi, 2008)

Figura 17 - Diagrama descritivo do artefato (fonte: Adaptado de Borsoi, 2008)

Figura 18 - Diagrama BPMN do detalhamento da atividade '2. Modelagem dos processos da fábrica de software' do método de instanciação... 60

Figura 19 - Exemplo do diagrama estrutural do processo e da atividade. .61

Figura 20 - Componentes essenciais do objeto processo (fonte: 
BORSOI,2008)

Figura 21 - Diagrama de estados do processo (fonte: Borsoi, 2008) 63

Figura 22 - Diagrama de estados da atividade (fonte: Borsoi, 2008).

Figura 23 - Diagrama de estados dos atores (fonte: Borsoi, 2008) . 63

Figura 24 - Diagrama de estados do artefato (fonte: Borsoi, 2008).

Figura 25 - Diagrama de fluxo de seqüência e de mensagens entre atividades

Figura 26 - Conceitos para representar fluxos de seqüência e de mensagem (fonte: BORSOI, 2008)

Figura 27 - Diagrama BPMN do detalhamento da atividade '3. Projeto dos processos da fábrica de software' do método de instanciação. 66

Figura 28 - objeto processo do método de instanciação.

Figura 29 - exemplo do termo de confidencialidade assinado entre os pesquisadores e empresa participante do experimento.

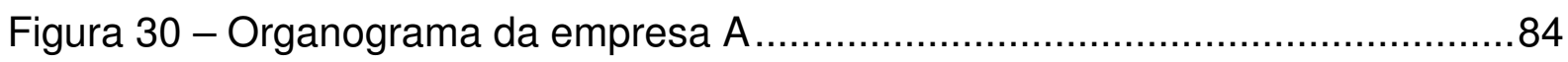

Figura 31 - Diagrama de estados do artefato da empresa A. .................................92

Figura 32 - Exemplo de diagrama estrutural do processo e da atividade da empresa A, para o processo de Gestão de acordos com fornecedores. 92

Figura 33 - Diagrama de fluxo de seqüência e de mensagens. Exemplo de diagrama comportamental da Empresa A..... 93

Figura 34 - Imagem do guia de processos da empresa A ....................................94

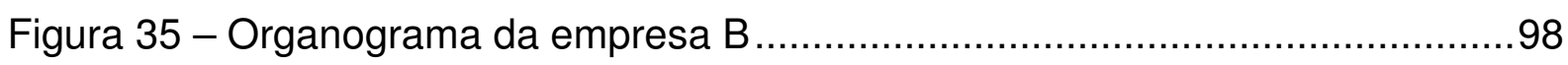

Figura 36 - Diagrama de estados do artefato da empresa B...............................102

Figura 37 - Exemplo de diagrama estrutural do processo e da atividade da empresa B, para o processo de Gestão de acordos com fornecedores..................102 Figura 38 - Imagem do guia de processos da empresa B. 103

Figura 39 - Diagrama de fluxo de seqüência e mensagens do processo de desenvolvimento da arquitetura de referência.

Figura 40 - Diagrama de fluxo de seqüência e mensagens do processo de desenvolvimento instanciado para empresa $\mathrm{B}$ 


\section{LISTA DE TABELAS}

Tabela 1 - Atividades versus produtos da metodologia utilizada neste trabalho

Tabela 2 - Relacionamento entre modelos e os diagramas que os compõe

Tabela 3 - Tabela de categorização de requisitos de negócio da fábrica por visões

Tabela 4 - matriz de requisitos de negócio e impacto nos objetos processos. 57

Tabela 5 - Categorização dos requisitos de negócio do projeto por visões. 69

Tabela 6 - Variáveis do experimento

Tabela 7 - Critérios das variáveis

Tabela 8 - Cronograma inicial das atividades na empresa A

Tabela 9 - Exemplo do cruzamento dos processos da arquitetura de referência aos processos já existentes na empresa $A$.

Tabela 10 - Resumo da tabela de identificação dos Requisitos de negócio da empresa $A$.

Tabela 11 - Tabela de categorização de requisitos de negócio da fábrica por visões, empresa A.

Tabela 12 - Resumo da matriz de impacto da empresa A.

Tabela 13 - Diagrama descritivo da atividade. Exemplo de diagrama estrutural da empresa A.

Tabela 14 - Análise das variáveis da aplicação experimental na empresa A ...........97

Tabela 15 - Requisitos de negócio da empresa B.

Tabela 16 - Tabela de categorização de requisitos de negócio da fábrica por visões, empresa $A$. 100

Tabela 17 - matriz de impacto da empresa $B$ 101

Tabela 18 - Análise das variáveis da aplicação experimental na empresa B 105 
LISTA DE ABREVIATURAS E SIGLAS

$\begin{array}{ll}\text { ABES } & \text { Associação Brasileira das Empresas de Software } \\ \text { BID } & \text { Banco Interamericano de Desenvolvimento } \\ \text { BPMN } & \text { Business Process Modeling Notation } \\ \text { CIM } & \text { Computer Integrated Manufactoring } \\ \text { CMM } & \text { Capability Maturity Model } \\ \text { CMMI } & \text { Capability Maturity Model Integration } \\ \text { FINEP } & \text { Financiadora de Estudos e Projetos } \\ \text { MCT } & \text { Ministério da Ciência e Tecnologia } \\ \text { MOF } & \text { MetaObject Facility } \\ \text { MPS.BR } & \text { Melhoria de Processo do Software Brasileiro } \\ \text { OMG } & \text { Object Management Group } \\ \text { RMODP } & \text { Reference Model Open Distributed Processing } \\ \text { SEPIN } & \text { Superintendência de Pesquisa e Informação } \\ \text { SOFTEX } & \text { Sociedade Brasileira para Promoção da Exportação de } \\ \text { Software } & \\ \text { SPEM } & \text { Software Process Engineering Metamodel }\end{array}$




\section{SUMÁRIO}

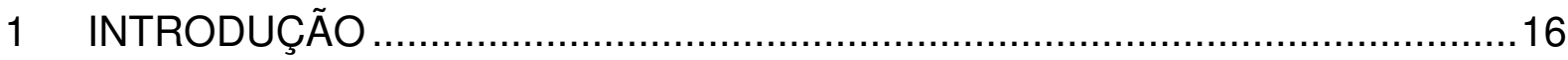

1.1 OBJETIVO

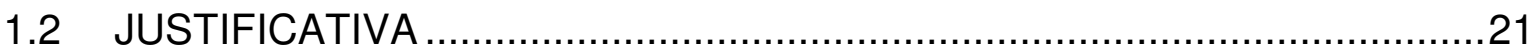

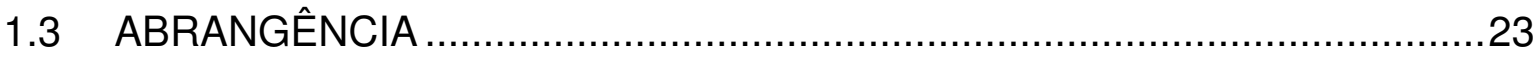

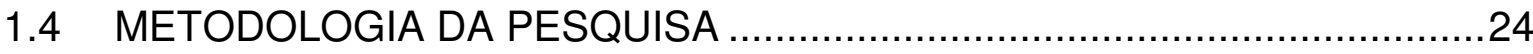

1.4.1 Estratégia da pesquisa baseada no quadrante de Pasteur ..................24

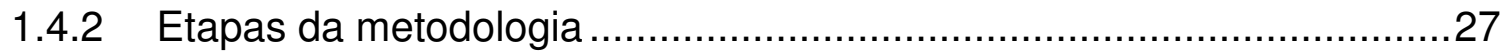

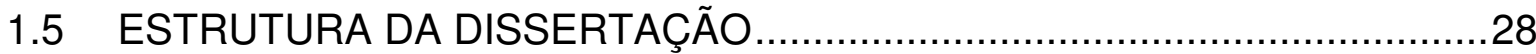

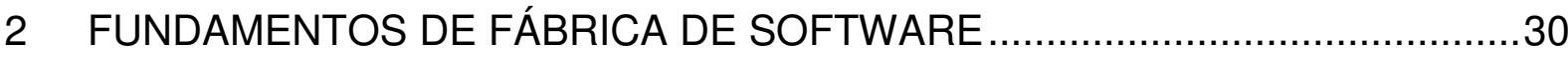

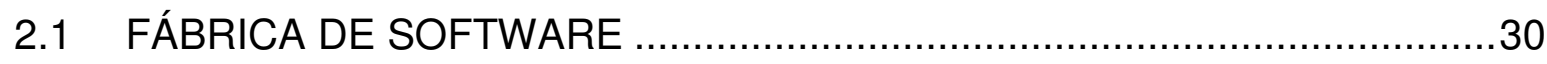

2.1.1 Definição de fábrica na manufatura ..................................................30

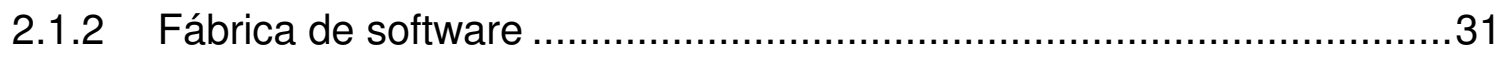

2.1.3 Modelo integrado de fábrica de software ............................................34

2.2 ESTADO DA ARTE SOBRE CRIAÇÃO DE PROCESSOS .........................36

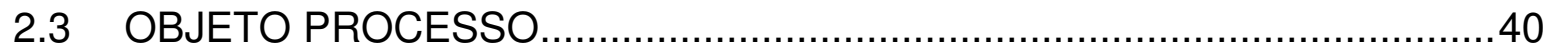

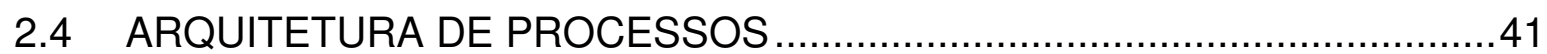

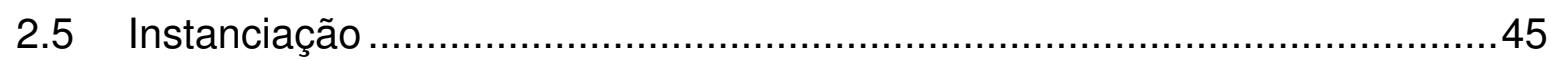

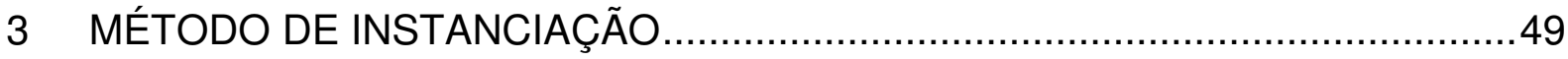

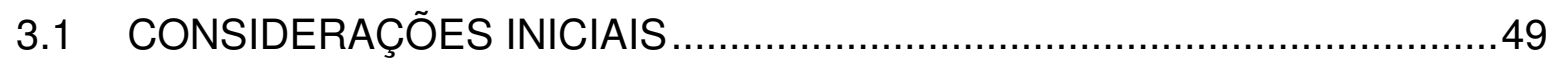

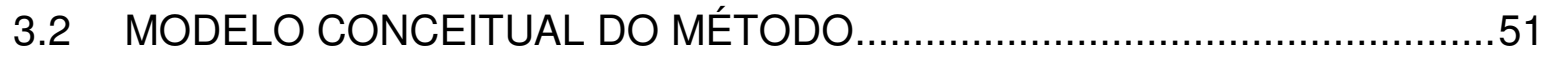

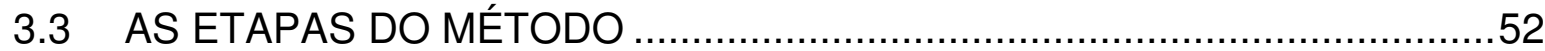

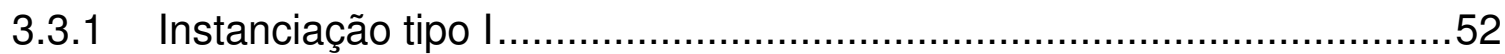

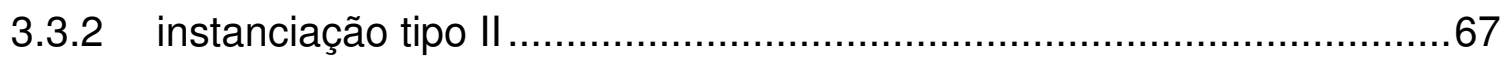

3.4 CONSIDERAÇÕES SOBRE APLICAÇÃO DO MÉTODO …........................70

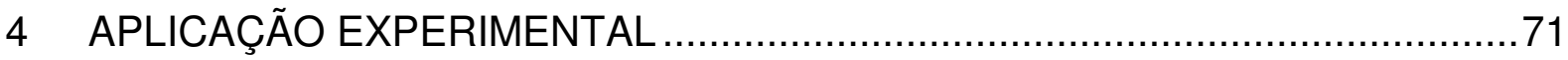

4.1 MODELO DA APLICAÇÃO EXPERIMENTAL...........................................71

4.2 OPERAÇÃO DA APLICAÇÃO EXPERIMENTAL ......................................72

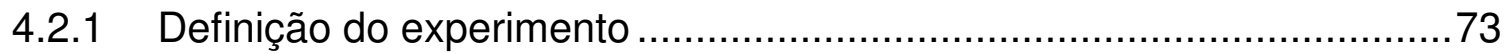

4.2.2 Planejamento do experimento ..................................................... 
4.2.3 Operação do experimento .................................................... 79

4.2.4 Interpretação dos experimentos ............................................. 105

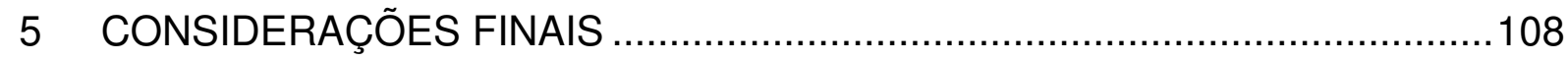

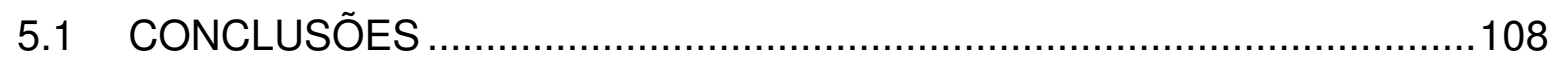

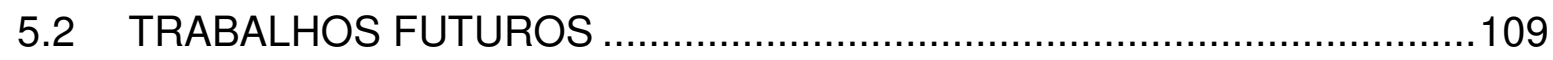

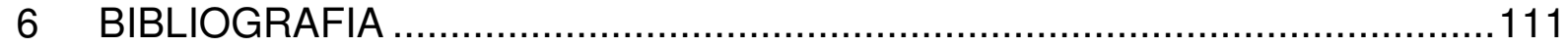




\section{INTRODUÇÃO}

O mercado mundial de software e serviços atingiu aproximadamente US\$873 bilhões em 2008 com o Brasil na 12a posição com um mercado de US\$14,67 bilhões ou $1,68 \%$ do mercado mundial e em torno de $0,96 \%$ do PIB brasileiro daquele ano. No período, o faturamento das empresas do setor foi de US\$15,01 bilhões. Detalhe que esta pesquisa não inclui os seguintes segmentos do setor de software e serviços: Software Embarcado, Software OEM, Software para Uso Próprio, Firmware - programas em linguagem básica integrados ao hardware e BPO (Business Process Outsourcing). ABES (2009).

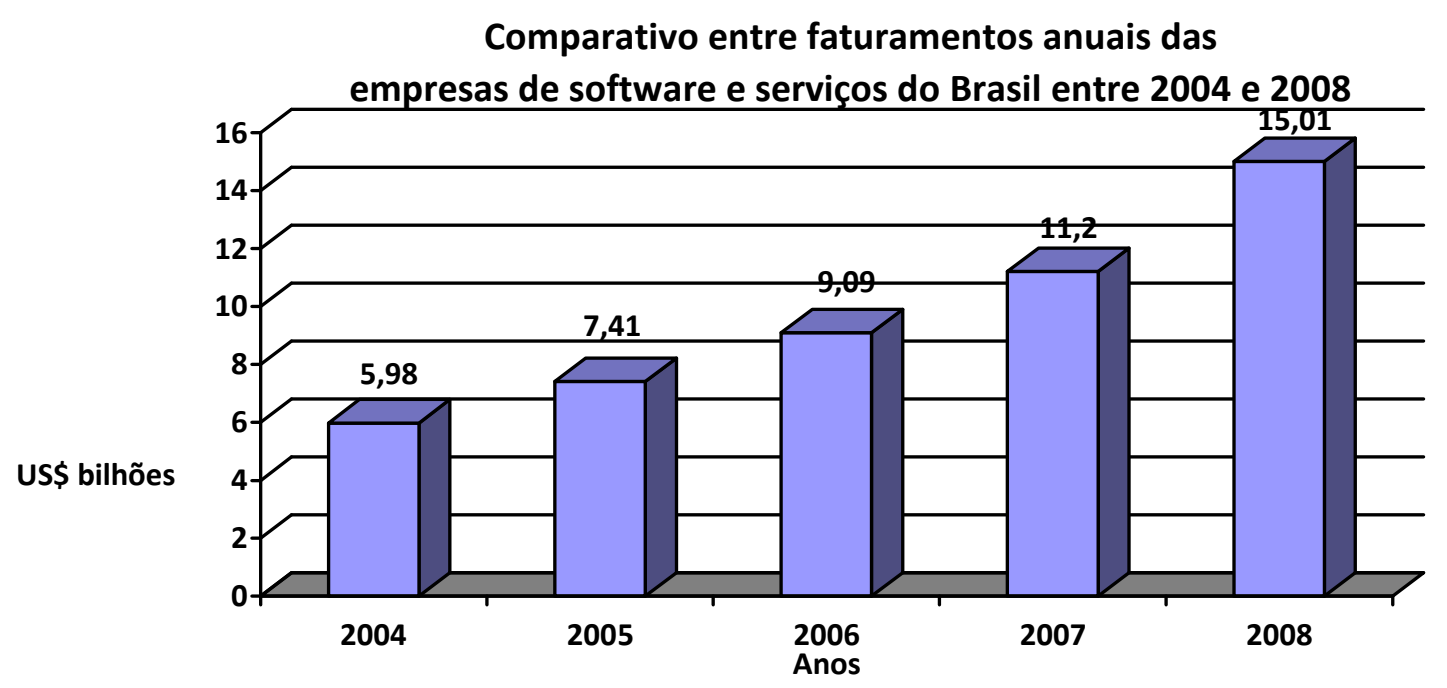

Gráfico 1 - Gráfico da evolução anula do faturamento das empresas de software e serviços brasileiras no período de 2004 a 2008. Fonte: Adaptado de ABES (2008)

O gráfico 1 apresenta o crescimento do faturamento do setor, um crescimento com expressivo que é fruto do aumento da demanda por serviços de software. Para manter tal crescimento as empresas desse setor necessitam de mais organização e qualidade justificando as pesquisas nessas áreas.

Mais uma evidência da importância da área de desenvolvimento de software para o país é a lei de informática criada pelo governo brasileiro para incentivar a área de 
desenvolvimento de software dentre outras. Esta lei torna evidente a atenção dada pelo governo brasileiro à indústria de software e também apresenta a intenção de fomentar a exportação dos produtos desta indústria. Seguem alguns trechos da lei que evidenciam a importância do software para o Brasil:

Art. 2ำ A Política Nacional de Informática tem por objetivo a capacitação nacional nas atividades de informática, em proveito do desenvolvimento social, cultural, político, tecnológico e econômico da sociedade brasileira, atendidos os seguintes princípios.

$X I$ - fomento e proteção governamentais dirigidos ao desenvolvimento de tecnologia nacional e ao fortalecimento econômico-financeiro e comercial da empresa nacional, bem como estímulo à redução de custos dos produtos e serviços, assegurando-Ihes maior competitividade internacional.(LEI № 7.232, DE 29 DE OUTUBRO DE 1984. PRESIDÊNCIA DA REPÚBLICA DO BRASIL, CASA CIVIL, SUBCHEFIA PARA ASSUNTOS JURÍDICOS)

A importância estratégica da indústria de software se evidencia na importância da exportação de software para a geração de riqueza do país. Segundo a ABES (2009) o total exportado em software foi de US\$340 milhões, número ainda muito pequeno, pois, representou apenas $2,27 \%$ do total de faturamento apontado para as empresas de software e serviços de 2008.

Segundo a pesquisa da SOFTEX UNICAMP (2005) uns dos fatores essenciais para a exportação de software em empresas brasileiras de capital nacional é se estruturarem para a necessidade de submeter-se a avaliação técnica feita pelo cliente, essa avaliação técnica se aplica tanto ao produto de software a ser comercializado, no caso de software prontos, como também em uma avaliação dos processos de desenvolvimento, subprodutos, técnicas, ferramentas e procedimentos utilizados durante o desenvolvimento de software. Segundo a mesma pesquisa para empresas de capital estrangeiro um fator importante é a certificação CMMI. (Capability Maturity Model Integration).

O Gráfico 2 apresenta as barreiras tecnológicas, organizacionais e produtivas mais citadas no questionário da pesquisa SOFTEX UNICAMP (2005) feito às empresas 
exportadoras de software brasileiras. O resultado apresenta a falta de certificações de qualidade (ex.: certificações ISO 9000, ISO 15504, CMMI e MPS.BR - Melhoria do processo de software brasileiro) e técnicas (ex.: língua inglesa, certificados de linguagens de programação), a falta de práticas que favoreçam a internacionalização do software (ex.: documentação no idioma inglês, suporte ao cliente, escritórios no países importadores) e a falta de escala para atender as demandas maiores como barreiras mais relevantes para exportação de software.

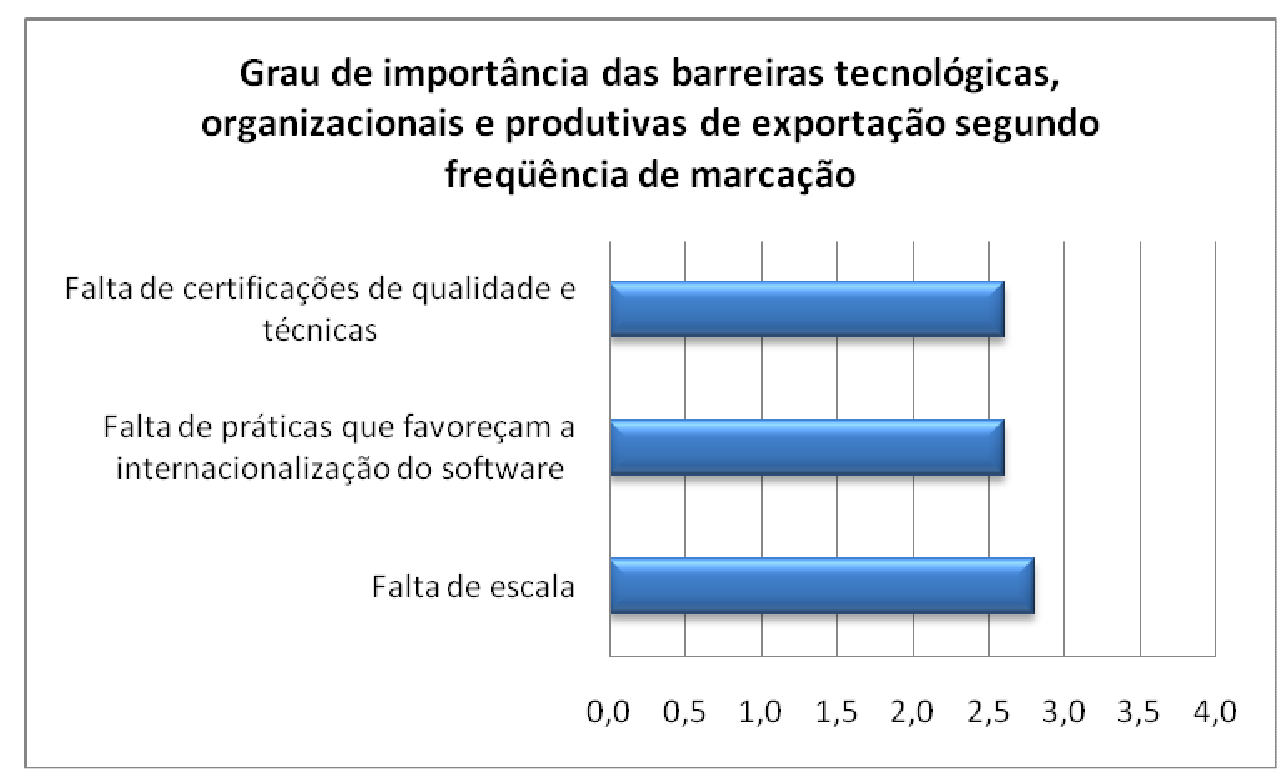

Gráfico 2 - Gráfico sobre o grau de importância das barreiras tecnológicas, organizacionais e produticas de exportação segundo freqüência de marcação. Fonte: Adaptado de SOFTEX UNICAMP (2005)

Como conclusão do Gráfico 2 é possível entender que para superar essas barreiras é importante que as empresas tenham processos de desenvolvimento flexíveis capazes de se adaptar as demandas de desenvolvimento do mercado e que estejam alinhados às melhores práticas dos modelos de qualidade.

Em dados divulgados através do Ministério da Ciência e Tecnologia, o Brasil, em setembro de 2005 , era o $13^{\circ}$ país em relação à certificações CMM com 49 avaliações e $011^{\circ}$ país em relação à certificações CMMI com 21 avaliações. MCT/SEPIN/DIA (2006). 
No entanto, apesar de todo o esforço do governo, a grande maioria das empresas não está aderente a nenhum modelo de qualidade em software. Uma das principais razões para tal é a falta de uma maneira sistemática para se inserir boas práticas, por exemplo, as recomendações do modelo MPS.BR (SOFTEX 2009), no processo de desenvolvimento de software. Ou seja, a questão chave é endereçar uma técnica para se definir processos de uma fábrica de software aderentes a um dado modelo de qualidade como ISOs 12207 e 15504, CMMI ou MPS.BR, e ao mesmo tempo contemplar os requisitos de negócio da empresa, que são necessidades particulares do ramo de atuação de cada fábrica de software.

A falta de uma maneira formal para adaptação de modelos de qualidade aos ambientes de desenvolvimento de software também é observada por Pedreira et al (2007). Os autores fizeram uma revisão sistemática em artigos sobre a adaptação de processos de software e mostram que $33 \%$ de todas as pesquisas analisadas não utilizaram abordagem formal. A mesma pesquisa mostrou também que apenas $20 \%$ dos trabalhos analisados aplicaram o método de adaptação do processo de software em pequenas empresas, sendo que, atualmente no Brasil, $57,5 \%$ das empresas de software e serviços são pequenas empresas (até 49 funcionários).

Como adaptar os modelos de qualidade para a criação de uma fábrica de software? Como adaptar ambientes de desenvolvimento de software existentes para trabalharem como fábrica de software de maneira integrada e aderentes a modelos de qualidade? Algumas pesquisas do Laboratório de Tecnologia de Software da Escola Politécnica da Universidade de São Paulo (LTS/Poli/USP) contribuem na linha de instanciação de boas práticas e modelos de qualidade para criação de fábricas de software, por exemplo, Panigassi (2007) apresenta um método para geração de processos de fábrica de software a partir de modelos de qualidade e requisitos de negócio da empresa. Borsoi (2008) segue a linha de pesquisa e apresenta um método para integração de fábricas de software através de arquitetura de processos, ou seja, permite a criação fábricas de software integradas considerando suas particularidades e adequadas a modelos de qualidade, como o CMMI, por exemplo.

Considerando-se este cenário crescimento e necessidade da indústria de software 
por processos organizados, modelos de qualidade diversos, necessidade de adaptação dos modelos para a realidade dos ambientes das fábricas de software, número reduzido de relatos sobre experimentos de adaptação de processos em pequenas empresas de software e importância do setor de desenvolvimento de software dentro da economia e da estratégia nacional, iniciou-se esta pesquisa que visa estudar o problema da instanciação de processos de desenvolvimento em um modelo de fábrica de software e aplicação no âmbito de empresa real.

\subsection{OBJETIVO}

O objetivo deste trabalho é apresentar um método de adaptação de processos de desenvolvimento para fábricas de software a partir de uma arquitetura de processos de referência gerada a partir de um modelo de qualidade e principalmente dos requisitos específicos da empresa. Esta adaptação é denominada instanciação de processo porque nesta dissertação o processo é considerado um objeto processo, que, quando é empregado em um ambiente determinado, esse objeto processo se instancia.

A agrupação de objetos processos de uma forma organizada determina uma arquitetura de processos de uma fábrica de software. Esta arquitetura ao se inserir em um domínio particular, ou de uma determinada empresa, ela deve se adaptar ou se instanciar como será mostrado nesta dissertação.

O método de instanciação foi elaborado utilizando o método criação de processos apresentado por Panigassi (2007), que forneceu uma seqüência de atividades para trabalhar os modelos de qualidade com o intuito de se criar processos. Borsoi (2008) foi importante para se entender o conceito de fábrica de software como um ambiente integrado para o desenvolvimento de software e para fundamentar a divisão dos processos, arquitetura de processos, de uma fábrica em níveis de abstração de processos da fábrica e processos do projeto.

Pesquisas sobre tailoring foram utilizadas para se compreender o estado da arte e entender sobre as principais necessidades para um método de instanciação. 
(PEDREIRA ET AL, 2007; PINO, GARCÍA E PIATTINI, 2007; XU, RAMESH, 2008; GINSBERG, M., QUINN, L. 1995)

Os experimentos foram realizados em duas empresas desenvolvedoras de software de pequeno porte (até 20 funcionários) seguindo-se as diretrizes para realização de um experimento em engenharia de software de Basili, Selby, Hutchens (1986). E este trabalho dá continuidade às pesquisas da engenharia de software experimental do grupo com empresas reais. Definindo um esquema padrão básico para a realização de experimentos em empresas de software reais, aproximando os problemas dessas empresas à pesquisa.

Por fim os resultados dos experimentos são compilados e sugestões de melhorias ao método proposto são estabelecidas, bem como sugestões ao processo de pesquisa envolvendo aplicação em empresas.

\subsection{JUSTIFICATIVA}

Este trabalho faz uso de um método baseado na arquitetura de processo. Diferente de outros métodos para implantação de processos que fazem uso de roteiros com dicas práticas para a adaptação de processos de desenvolvimento, ou que utiliza um único modelo (fluxogramas ou diagrama de classes) de processos para trabalhar a instanciação como, por exemplo, Xu e Ramesh (2008), Hikichi et all (2006), Ginsberg e Quinn (1995), o método utilizado neste trabalho é conceitual como Hikichi, e estruturado assim como Ginsbert e Quinn, fornecendo diversos modelos estruturais e comportamentais com níveis de abstração diferentes, facilitando a análise durante a instanciação.

Segundo Roselino (2006) o próprio processo produtivo do software pode ser percebido como uma seqüência articulada de etapas em diferentes níveis organizacionais, mas adaptáveis a estratégia da empresa. Esta constatação mostra que a fábrica de software necessita ser um modelo flexível que possa ser adotado em diferentes proporções por diferentes instituições com o mesmo objetivo, isto é, obter software de qualidade dentro dos prazos e dos custos. A instanciação da a 
flexibilidade necessária para o processo de software.

O conceito de fábrica de software utilizado neste trabalho não deve ser entendido ou comparado a produção em massa, o conceito utilizado é o mesmo proposto por Aaen, Bothcer e Mathiassen (1997), onde a fábrica de software possui pessoas, padrões e é organizada, porém não de uma maneira única, permitindo projetar várias opções diferentes para uma fábrica de software específica.

As empresas precisam constantemente adaptar seus processos aos objetivos dos projetos que constantemente evoluem e se adaptar às necessidades dos negócios. Porém, o entendimento sobre a adaptação ainda é limitado. (XU, RAMESH, 2008)

A adaptação dos processos não é apenas uma aplicação de uma versão reduzida dos modelos de qualidade CMMI, ISO e MPS.BR como acontece nas grandes empresas. É necessário possuir um método coerente para implantar a melhoria do processo de software, além de rastrear e supervisionar as melhorias propostas versus os objetivos desejados. Esses são uns dos fatores de sucesso que Pino, García e Piattini (2008) citam após realizarem uma revisão sistemática sobre a melhoria de processos de software em pequenas e médias empresas.

Esta dissertação dará continuidade aos trabalhos sobre fábrica de software do Laboratório de Tecnologia de Software da Escola Politécnica. Definição de fábrica de Software, Modelagem de fábrica de software, Criação de processos para fábrica de software e arquitetura de processos de fábrica de software. (BECERRA; CABEL; LEVY, 2007) e (BORSOI 2008)

A parte experimental deste trabalho, por se tratar do uso da engenharia de software experimental, traz informações sobre o método de instanciação em pequenas empresas reais que ajudam a aumentar o entendimento e melhorar o processo de software (BASILI, 2006), um tema prático, pouco explorado (PEDREIRA et al, 2007) e que contribui muito para o avanço de novas abordagens. As grandes empresas possuem processos complexos muitas vezes modelos de qualidade já estabelecidos como CMMI nível 3, desta maneira instanciam processo de software de maneira empírica sem uma sistemática formal. Já uma pequena empresa não é da mesma 
maneira, então um esforço destinado a aumentar o conhecimento sobre o tema é relevante.

A organização da aplicação desta pesquisa dentro de um esquema experimental abre um novo vetor dentro do grupo, servindo de exemplo para novos trabalhos experimentais a serem feitos. Além disso, os experimentos realizados servirão para análises posteriores a fim de explicar o fenômeno de instanciação de maneira mais formal, pois experimentos são necessários para o avanço da pesquisa e da prática em engenharia de software. (FREMUT ET AL. 2002, APUD TICHY, 1998) e (BASILI, LANUBILE, 1999)

\subsection{ABRANGÊNCIA}

É importante salientar que o método de instanciação deste trabalho é um incremento ao método proposto por Borsoi (2008), que somente cita o tema instanciação, mas não o trata, e que faz uso da arquitetura de processos.

Quanto à arquitetura de processos, este trabalho não discutirá a criação da teoria de arquiteturas de processos e sua utilização em fábricas de software, pois esta já foi feita por Borsoi (2008). Será feito o uso desta teoria a fim de organizar os processos e passos do método de instanciação. A arquitetura favorece o entendimento, organização e análise dos processos através de suas visões.

O modelo de fábrica de software utilizado nesta pesquisa é a arquitetura de processos, os outros elementos que constituam uma fábrica, são representados pela outras visões do modelo de fábrica de software, mas não serão representados na arquitetura de processos.

O método de instanciação proposto, que para muitos autores é o método de criação de processos ou método de adaptação de processos será complementado com pesquisas recentes com o tema tailoring como, por exemplo, a pesquisa de Xeng e Ramesh, 2008 que traz um roteiro rápido de adaptação do processo de desenvolvimento através da identificação dos desafios do projeto, também se tem o trabalho de Ginsberg, M. Quinn, L. 1995 que apresenta um método de tailoring do 
CMM.

A aplicação do método em empresas reais seguirá uma metodologia para a definição e realização de experimentos de engenharia de software. A metodologia visa garantir que o experimento possa ser repetido no futuro por outros pesquisadores e também que os dados coletados tenham validade cientifica.

Os experimentos não propõem validar nem mesmo comprovar o método em sua totalidade, são apenas registros do uso do método em condições e situações bem definidas e como resultados provam que nos contextos experimentados a eficácia.

\subsection{METODOLOGIA DA PESQUISA}

Neste capítulo serão abordados a metodologia utilizada na pesquisa constituída pela estratégia de pesquisa baseada no quadrante de Pasteur e da metodologia utilizada por esta disseração. Cabe ressaltar que a metodologia dessa dissertação baseia-se no quadrante de Pasteur.

\subsubsection{Estratégia da pesquisa baseada no quadrante de Pasteur}

A metodologia de pesquisa utilizada neste trabalho busca estender as fronteiras do entendimento, mas também está inspirada por considerações da aplicação. Essa modalidade de pesquisa é conhecida como quadrante de Pasteur. O nome de Pasteur é dado a esse tipo de pesquisa, pois apresenta a busca pelo entendimento aliado ao uso, essa combinação de objetivos é muito bem ilustrada pelos tipos de pesquisa realizados por Pasteur. (STOKES, 1997) 
Pesquisa inspirada por: Considerações de uso ?

Busca

\begin{tabular}{ll|c|c|}
\multicolumn{1}{c}{} & \multicolumn{1}{c}{ Não } & \multicolumn{1}{c}{ Sim } \\
\cline { 2 - 3 } $\begin{array}{l}\text { Busca } \\
\text { de conhecimento } \\
\text { fundamental? }\end{array}$ & $\begin{array}{c}\text { Pesquisa } \\
\text { básica pura } \\
\text { (Bohr) }\end{array}$ & $\begin{array}{c}\text { Pesquisa } \\
\text { básica } \\
\text { inspirada } \\
\text { em uso } \\
\text { (Pasteur) }\end{array}$ \\
\cline { 2 - 3 } & Não & $\begin{array}{c}\text { Pesquisa } \\
\text { aplicada } \\
\text { (Edison) }\end{array}$ \\
& &
\end{tabular}

Fonte: Pasteur's Quadrant: Basic Science and Technological Innovation, Donald E. Stokes, Brookings Institution Press , 1997

Figura 1 - Quadrante de Pasteur

O modelo proposto na figura 1 por Strokes (1997) divide as formas de se fazer pesquisa em quadrantes. No quadrante de Bohr estão as pesquisas básicas interessadas somente em aumentar 0 entendimento fundamental sem a necessidade de obter uma aplicação como um resultado. No quadrante de Edison as pesquisas são realizadas somente com a intenção de se alcançar uma aplicação prática.

A pesquisa baseada no quadrante de Pasteur é uma pesquisa que não é puramente teórica, utiliza-se de experimentos e aplicações práticas para coletar informações sobre o que está sendo estudado. A pesquisa apoiada neste quadrante também não é apenas a aplicação de conceitos previamente existentes e a coleta de dados, o que poderia ser considerado um projeto de engenharia, é uma pesquisa que faz uso da aplicação prática para aumentar o entendimento, validar e testar hipóteses sobre um determinado tema.

Dentro do quadrante de Pasteur pode haver pesquisas com diferentes intensidades de busca de conhecimento teórico e de aplicações. O Gráfico 3 será utilizado para dissertar sobre os tipos de pesquisas baseadas no quadrante de Pasteur. 
O losango do gráfico chamado de P1 apresenta uma pesquisa dentro do quadrante de Pasteur que faz uma busca exploratória pelo conhecimento, mas com um objetivo prático, porém, pequeno se comparado ao objetivo da pesquisa representada pela figura do quadrado, pesquisa P2.

A pesquisa P2 tem um forte objetivo de aplicação prática, busca resolver um problema através da aplicação de um conhecimento, mas também tem a preocupação de aumentar o entendimento sobre o problema. A pesquisa representada por P2 pode ser comparada a pesquisa apresentada neste trabalho, pois existe um método detalhado para a instanciação de processos em fábricas de software que é proposto e este é analisado após observação dos resultados de experimentos realizados em empresas reais.

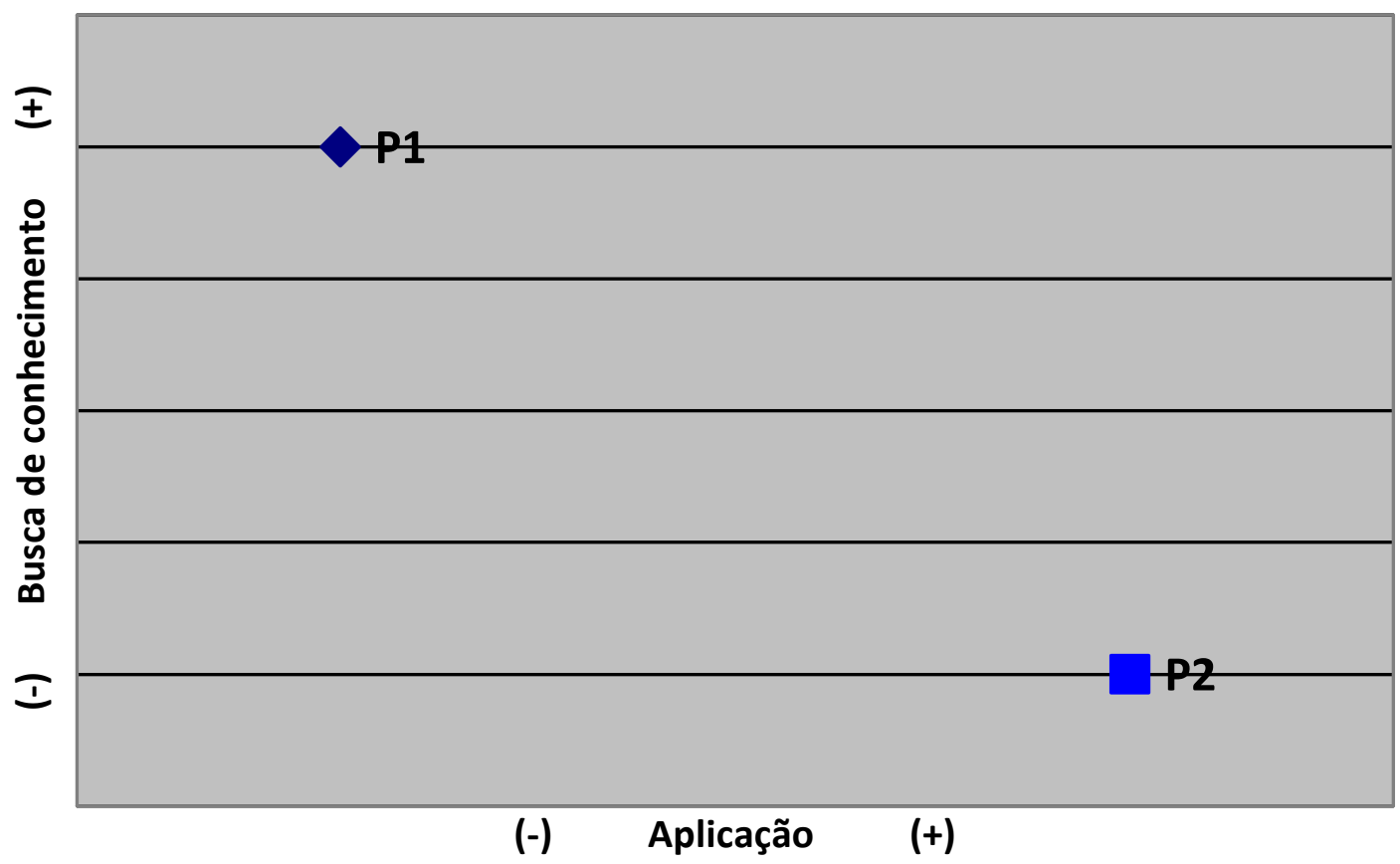

Gráfico 3 - A pesquisa deste trabalho no quadrante de Pasteur.

Segundo o eixo vertical, visa-se a identificação detalhada dos conceitos e elementos mais importantes da instanciação e como trabalhá-los corretamente.

Segundo o eixo horizontal, visa-se realizar experimentos para enriquecer e avaliar o método proposto com o objetivo de facilitar a instanciação de fábricas. 
A pesquisa não poderia ser considera de Bohr, pois tem uma preocupação com uma aplicação prática e também não poderia ser considerada de Edison, pois, apesar da aplicação prática, busca aumentar o entendimento sobre o a instanciação e seus elementos.

\subsubsection{Etapas da metodologia}

Diante do esquema de Pasteur, a metodologia utilizada neste trabalho seguiu as etapas apresentadas na Tabela 1:

\begin{tabular}{|c|c|c|}
\hline ETAPAS & ATIVIDADES & PRODUTOS \\
\hline 1 & Identificação do problema & $\begin{array}{l}\text { Definição do objetivo } \\
\text { científico teórico e do } \\
\text { objetivo científico prático e } \\
\text { abrangência. }\end{array}$ \\
\hline 2 & $\begin{array}{l}\text { Levantamento Bibliográfico sobre os } \\
\text { temas: fábrica de software, Arquitetura de } \\
\text { processos, Instanciação de processos }\end{array}$ & $\begin{array}{l}\text { Capítulo } 2 \text { Teoria deste } \\
\text { trabalho }\end{array}$ \\
\hline 3 & Definição do método & $\begin{array}{l}\text { Guia de aplicação do } \\
\text { método contendo as } \\
\text { atividades e sua seqüência } \\
\text { e Capítulo } 3 .\end{array}$ \\
\hline 4 & Levantamento de empresas candidatas & $\begin{array}{l}\text { Relatório de análise de } \\
\text { candidatos baseado nos } \\
\text { projetos desenvolvidos por } \\
\text { eles e comprometimento } \\
\text { com o experimento }\end{array}$ \\
\hline 5 & $\begin{array}{l}\text { Aplicação do método nas empresas } \\
\text { segundo metodologia para se definir e } \\
\text { realizar experimentos }\end{array}$ & $\begin{array}{l}\text { Relatório de resultados } \\
\text { obtidos e análise. Capítulos } \\
4 \text { e } 5 \text { da dissertação }\end{array}$ \\
\hline 6 & Redação dos capítulos finais do trabalho & $\begin{array}{lllll}\text { Capítulos } & 6 & \text { e } & 7 & \text { da } \\
\text { dissertação } & & & & \end{array}$ \\
\hline
\end{tabular}

Tabela 1 - Atividades versus produtos da metodologia utilizada neste trabalho 
- Etapa 1 - Esta etapa é a busca pelo problema teórico e prático da pesquisa, pois se está trabalhando com uma pesquisa dentro do quadrante de Pasteur. Procura-se entender até onde irão os estudos e os experimentos propostos a fim de se definir a escopo do trabalho como um todo;

- Etapa 2 - Esta etapa consiste num levantamento detalhado sobre os temas relevantes para a pesquisa como Instanciação de processos, Fábricas de software, arquitetura de processos e engenharia de software experimental;

- Etapa 3 - Esta etapa é a criação do método fundamentado nas teorias estudadas;

- Etapa 4 - Esta etapa é a busca e seleção das empresas candidatas;

- Etapa 5 - Esta etapa é aplicação do método de instanciação em empresas seguindo-se a metodologia para realização de experimentos e relatório dos resultados encontrados;

- Etapa 6 - Esta etapa é a análise do trabalho como um todo e reflexão sobre a área de pesquisa e trabalhos futuros que podem ser realizados.

\subsection{ESTRUTURA DA DISSERTAÇÃO}

A estrutura da dissertação é apresentada a seguir:

- Capítulo 1 - Introdução sobre o tema, considerações iniciais, objetivo da pesquisa, justificativa baseada em outros estudos, a abrangência do trabalho e a metodologia utilizada;

- Capítulo 2 - Capítulo que apresenta a teoria envolvida no trabalho apresentase o entendimento sobre fábrica de software, sobre criação de processos em ambientes de desenvolvimento de software, o objeto processo e a arquitetura de processos; 
- Capítulo 3 - é a proposta da pesquisa. É o detalhamento sobre o método de instanciação de fábricas de software. É apresentado o conceito de instanciação, o método de instanciação, e como e porque foi elaborado;

- Capítulo 4 - é apresentada a metodologia a ser utilizada no experimento. São apresentados como foram selecionadas as empresas, como são essas empresas, como foi a aplicação do método em cada empresa e os resultados;

- Capítulo 5 - Os resultados são discutidos e melhorias ao método são propostas;

- Capítulo 6 - Conclusão do trabalho como um todo. Serão apresentadas as contribuições desta pesquisa, considerações finais e os trabalhos futuros que podem ser realizados a partir desta. 


\section{FUNDAMENTOS DE FÁBRICA DE SOFTWARE}

Neste capítulo serão apresentados os conceitos e teorias utilizados neste trabalho. Primeiramente se explorará o entendimento sobre o tema fábrica de software em seguida será discutido o estado da arte em projetos de criação de processos. A arquitetura de processos e os objetos processos também serão esclarecidos a fim de se compreender o fenômeno da instanciação de processos.

\subsection{FÁBRICA DE SOFTWARE}

Neste capítulo será discutido o termo fábrica de software através da criação um paralelo entre a evolução do termo fábrica da manufatura e a evolução do termo fábrica de software até se chegar à compreensão atual.

\subsubsection{Definição de fábrica na manufatura}

Fábrica é um termo amplamente utilizado para designar produção com o auxílio de máquinas de forma a aumentar a eficiência produtiva durante a revolução industrial no século XVII. Naquela época também se chamavam fábricas, por exemplo, conjuntos de artesãos que produziam tecidos em um mesmo local com pouco auxílio de máquinas, mas eles compartilhavam a administração dos custos e dos insumos. Mais tarde o termo evolui com Henry Ford, ele propõe e monta uma fábrica em linha de montagem para produção em massa, onde utilizou avançados métodos estatísticos para o controle de qualidade, e, as etapas de produção e as atividades de cada funcionário eram bem definidas, isso permitiu a produção de bens a um custo menor. (RECCO, C. CATARIN, C. BANDOUK, G, 2009)

Seguindo o curso da evolução surge a robotização, cujo objetivo final era substituir completamente a mão de obra das fábricas por robôs e equipamentos de automação, esta é a fábrica automatizada do ponto de vista da linha de produção e não das outras áreas da fábrica como por exemplo marketing, contabilidade, pesquisa e desenvolvimento de produtos. $O$ objetivo da robotização era tornar automáticas através de robôs as atividades realizadas por seres humanos na produção, tirar os seres humanos da linha de produção. 
Então com o passar do tempo surge a definição de CIM (Computer Integrated Manufactoring) como um sistema integrado que combina diversas áreas da empresa como as áreas de produção, marketing e pesquisa e desenvolvimento para gerenciar e operar sobre uma única gerência estratégica com o apoio de computadores.

Desta forma, a operação da produção pode ser mais eficiente e flexível. O CIM entende a fábrica como uma corporação (Enterprise) e não somente como uma linha de produção, ou seja, entende a fábrica como uma organização formada por diversos processos dos diferentes departamentos da fábrica e que devem estar alinhados aos objetivos estratégicos e não somente aos objetivos de cada departamento. Cabe ressaltar que este conceito não se refere a uma fábrica completamente automatizada, porém completamente integrada. (JORYSZ AND VERNADAT 1990)

O objetivo desse item foi apresentar a evolução do termo fábrica na história, partindo de um conceito inicial onde o entendimento sobre fábrica se continha somente no processo produtivo até um conceito de fábrica do CIM, que um conceito mais abrangente que considerada a fábrica como uma corporação e possui diversos processos e todos integrados para uma maior eficiência e é este o contexto da fábrica utilizado nesta dissertação. A seguir irá se realizar uma apresentação semelhante, porém com o termo fábrica de software e sua evolução.

\subsubsection{Fábrica de software}

O termo fábrica de software teve sua origem nos anos 60 e 70, nos Estados Unidos e no Japão segundo Cusumano (1991), quando companhias da indústria de software iniciaram o uso do termo fábrica. A primeira fábrica de software foi da Hitachi Software em 1969, sendo uma proposta dos executivos em separar as instalações de desenvolvimento de software quando o desenvolvimento se tornou uma atividade maior. Os objetivos desta fábrica eram produtividade e confiabilidade através da padronização de processos e controles, e a transformação do software de um serviço desestruturado para um produto com nível de qualidade assegurado. 
Em seguida surgem as fábricas de software dos Estados Unidos como, por exemplo, a System Development Corp. que se tornou parte da Unisys mais tarde. A primeira filial desta empresa a adotar o sistema de fábrica de software foi em Santa Monica na Califórnia onde havia 200 programadores. O plano dessa fábrica envolvia o processo e a organização com três elementos sendo:

- Um conjunto integrado de ferramentas (base de dados, biblioteca de programas, sistemas automatizados para verificação e documentação);

- Procedimentos e políticas de gerenciamento padronizados;

- Uma organização em matriz que separa os projetos de sistemas em alto nível (feito nos clientes) dos desenvolvimentos de programas (feito na fábrica de software)

Estes esforços iniciais na direção de fábricas de software têm como semelhanças a criação de organizações centralizadas e sistemas específicos de gerenciamento e controle para famílias de produtos, métodos e ferramentas padronizados para produção destes produtos e suporte automatizado para o desenvolvimento e o gerenciamento do projeto.

Para Cantone (1992), uma fábrica de software deve: ser flexível, capaz de produzir produtos dentro de um segmento de mercado; implementar os conceitos de engenharia de software (metodologia e ferramentas); capaz de analisar, projetar, implementar, evoluir e melhorar os sistemas. Esta definição se apresenta mais abrangente, considerando fábricas de software empresas que desenvolvem software, mas não somente através da linha de montagem com montagem de componentes.

A afirmação que uma fábrica de software não deveria ser analisada como na manufatura, já foi discutida por Rockwell e Gera (1993). No entendimento dos autores não se pode utilizar o mesmo processo de software para produtos diferentes. Desta maneira, o entendimento do produto a ser feito torna-se indispensável. E para isso, o entendimento do mercado é necessário o que traz a 
idéia da fábrica dentro do conceito da corporação. Pois a fábrica de software é, muitas vezes, um departamento da corporação que, por sua vez, deve apresentar resultados financeiros, ter controles de custos, prazos, qualidade e ter respostas em curto e longo prazo para mudanças de requisitos de software.

Segundo Cusumano (1989), o conceito de fábrica de software como linha de montagens de componentes existentes, reutilizando-os parece ser muito difícil, pois seria necessário criar módulos que devem ser eficientes e confiáveis para todos os tipos de sistemas e que não restrinjam o usuário. Deve-se se entender tal afirmação não como uma restrição, mas sim como um desafio que engenheiros de software devem superar, ou seja, no futuro fábricas de software deverão estar organizadas desta maneira, para simplesmente serem montadoras de sistemas, mas ainda não é a realidade atual.

Para Li, Li e Li (2001), a essência da fábrica de software pode estar sintetizada nos conceitos focados no método de gerenciamento e de desenvolvimento. Panigassi (2007) faz uso dessa definição. Para o autor a fábrica de software é a organização previsível e controlada dos elementos que compõem o desenvolvimento do software. Estes elementos são processo, recursos e conhecimento.

A definição de Panigassi (2007) é completa, pois não limita a fábrica de software a uma empresa destinada somente a codificação, ou uma empresa que execute todo o ciclo de vida do software. Na definição se enquadram fábricas de especificações, arquiteturas ou testes, contanto que sejam organizadas e controladas.

Segundo Borsoi (2008), fábrica de software é um ambiente de desenvolvimento de software constituído por processos que envolvem o ciclo de vida de software e são categorizados em níveis hierárquicos corporativos: estratégico, gerencial e operacional. Os processos são definidos de acordo com normas e modelos de qualidade.

A definição de fábrica de software utilizada neste trabalho foi elaborada a partir da definição de Borsoi (2008), incluindo nesta definição que o ambiente de software para ser chamado de fábrica deverá ser criado a partir dos requisitos de negócio da 
empresa e fazer parte de uma organização. Esta definição abrangente envolve as atividades operacionais ligadas à produção do software, às atividades de gestão e controle, às ações estratégicas de negócio (missão, metas, objetivos) e envolve os sistemas de informação. Contextualizando a fábrica de software como processos controlados dentro de uma organização e estruturados em níveis hierárquicos. Assim, tem-se a fábrica de software alinhada com o conceito de CIM (Computer Integrated Manufactoring)

\subsubsection{Modelo integrado de fábrica de software}

A fábrica de software integrada é uma empresa que contem todos os departamentos organizacionais necessárias para a realização de sua atividade fim. Quando a empresa tem como processo principal de negócio o desenvolvimento de software a fábrica de software é o departamento principal. Quando a empresa não tem como processo de negócio principal o desenvolvimento de software o departamento de fábrica de software dá suporte aos outros departamentos da empresa.

A figura 2 apresenta a fábrica de software como um todo constituído por níveis hierárquicos, departamentos organizacionais e visões.

Os níveis hierárquicos agrupam em camadas as funções dos diversos departamentos como são mostrados a seguir:

- Estratégico - reúne os processos ligados ao direcionamento e à tomada de decisões do negócio. Os processos estratégicos trabalham com a missão, metas e objetivos da empresa;

- Gerencial - reúne os processos que controlam e supervisionam os processos operacionais. Os processos são responsáveis pela garantia da qualidade do que é desenvolvido pela organização;

- Operacional - reúne os processos que executam as atividades de desenvolvimento dos produtos da organização; 


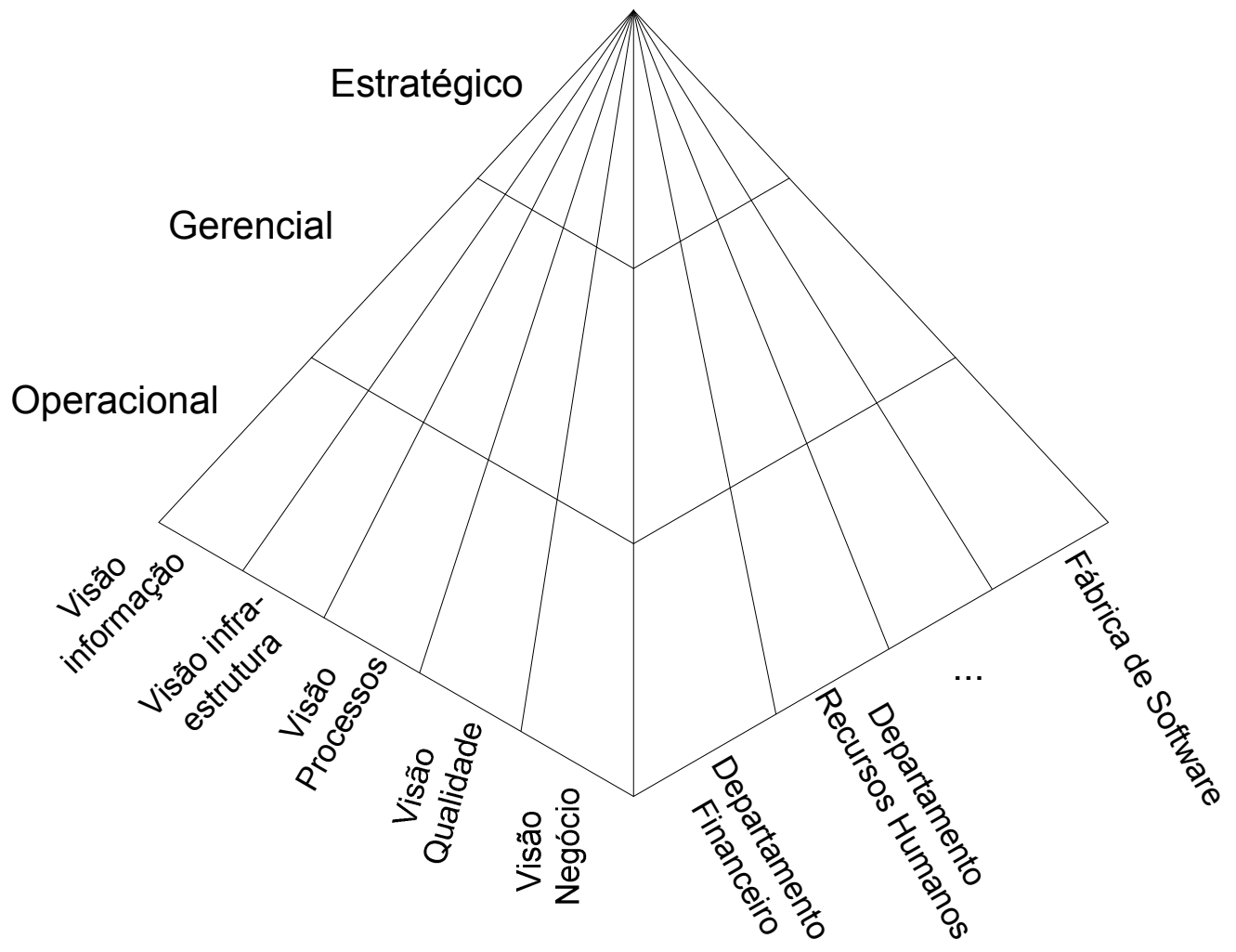

Figura 2 - Visões da fábrica de software integrada

Os departamentos são um dos elementos do modelo da fábrica de software que representa as divisões da organização por funções. Estas funções reúnem especialidades.

Por fim, o modelo possui também visões que representam as diversas características da fábrica de software como é mostrado no RM-ODP (RMODP,1996). Cada visão possui modelos distintos que tem por objetivo facilitar a análise, como por exemplo, o modelo de informação que descreve a informação gerada e manipulada na organização e serve de base para a automação dos artefatos produzidos.

Seguindo o modelo de fábrica de software integrada a seguir citam-se alguns tipos de fábrica de software: 
- Segundo a visão de processo observando o processo de desenvolvimento tem-se a fábrica de programação, a fábrica de componentes, a fábrica de especificações, ou a fábrica que desenvolve o software como um todo, realizando todas as atividades relacionadas ao ciclo de vida de software, abrangendo da definição dos requisitos até a descontinuidade do produto, incluindo suporte e manutenção;

- Segundo os departamentos organizacionais a fábrica de software pode ser a empresa como um todo ou um departamento de uma empresa, que é responsável por produzir ou adquirir software alinhado às necessidade de negócio da organização.

Também é possível ter fábricas de software de componentes, ou fábrica de software de família de produtos, ou fábrica de software somente que especificam software. Essas fábricas de software estando dentro de uma organização ou sendo elas a organização como um todo. Essa diferenciação dos tipos de fábricas não se dará pelos níveis hierárquicos e nem pelo número de áreas funcionais e sim pelo conteúdo das diferentes visões que contém as características de cada fábrica, características estas que serão chamadas de requisitos de negócio.

Desta maneira, para a análise da instanciação de processos esta dissertação fará uso da visão processo e seus modelos, pois é a visão utilizada para elaboração da arquitetura de processos. As demais visões servirão como requisitos de negócio que deverão ser trabalhados pelo método de instanciação a fim de se criar fábricas de software para os diferentes contextos de negócio existentes.

\subsection{ESTADO DA ARTE SOBRE CRIAÇÃO DE PROCESSOS}

Este item apresenta o estado da arte em relação ao projeto de criação de processos.

Segundo Derniame, Kaba e Wastel (1999), metaprocesso é um processo de alto nível que inclui os passos para se definir modelo de processo ou mesmo o processo real. Meta-processo é um processo para se definir um processo. 
Segundo esses autores meta-processos existentes atualmente são o CMMI, SPICE, ISO 12207. Estes modelos mais normativos, focando na evolução dos aspectos reais do processo executado pelas pessoas e com auxílio de ferramentas. Existe também meta-processos focados na evolução do modelo de processos, estes modelos de processos são representações das atividades reais e servem como guias, direcionamento, ou para automação do processo produtivo.

Segundo Conradi (1997) apud Derniame et. al. (1999), não é possível identificar um meta-processo universal para todos os possíveis processos. Entretanto, é possível se definir algumas atividades gerais, que constituem o esqueleto de qualquer metaprocesso, como é mostrado a seguir:

Provisão de tecnologia: atividade responsável por adquirir ou produzir o apoio a produção e apoio ao processo.

Análise de requisitos de processo: Está atividade leva em conta o processo de produção, o meta-processo e o processo de apoio existente para prover requisitos para a meta-atividade de modelagem.

Modelagem do processo: Quando um novo processo é criado, ou se o novo requisito para um processo existente é identificado, esta atividade detalhada o processo.

Implementação do processo: Esta atividade está incumbida de implementar o modelo criado na atividade anterior. Implementação do processo incluem aspectos conceitualmente distintos, 1) mudança do suporte do processo e 2) mudança do processo do mundo-real.

Avaliação de processo: Esta atividade provê informações quantitativas e qualitativas descrevendo o desempenho do processo como um todo.

Baseado nestas premissas e outras pesquisas Derniame propõe o modelo de referência chamado PROMOTER. A Figura 3 a seguir apresenta o modelo: 


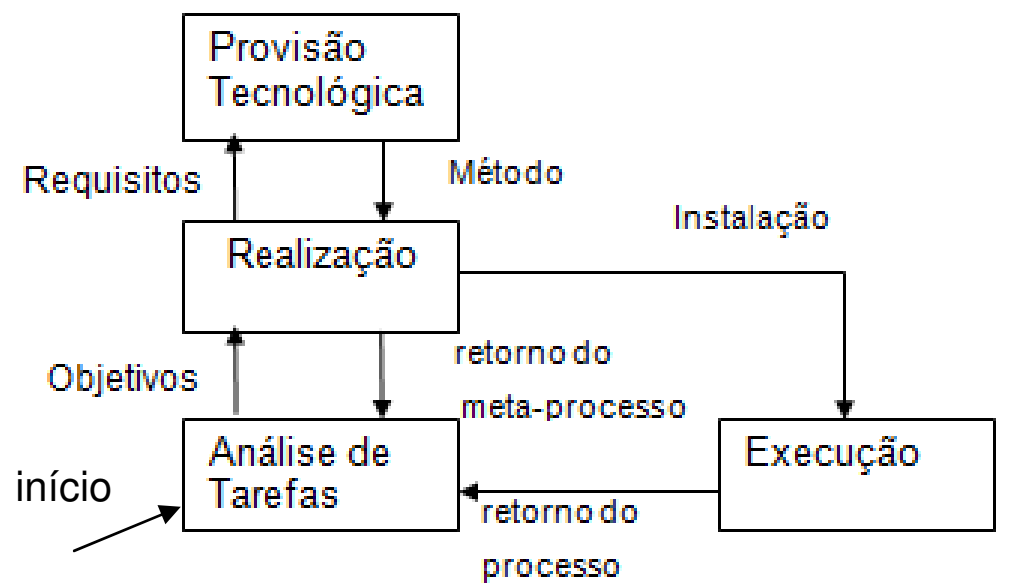

Figura 3 - modelo de referência PROMOTER (adaptador de DERNIAME, KABA, WASTELL, 1999)

Análise de tarefas: definição dos objetivos para uma tarefa particular atingir uma meta.

Provisão Tecnológica: provisão de um modelo de definição do método para executar a tarefa.

Realização: adaptação deste modelo ao contexto organizacional e então associar os objetivos específicos com o modelo.

Execução: corresponde ao trabalho dos executores das tarefas guiados pelo modelo de execução.

Panigassi (2007) também possui um meta-processo, para o autor o processo de definição de uma fábrica de software aderente ao CMMI é proposto seguindo por analogia as etapas do processo de desenvolvimento de software. (Elicitação dos Requisitos, Especificação, Modelagem, Projeto e Implantação). Todas as etapas visando a definição da fábrica no âmbito de processos. O trabalho de Panigassi (2007) objetiva desde a definição dos requisitos de processos até a implantação dos processos de uma fábrica de software como é apresentado a seguir:

- Elicitação dos objetivos da fábrica de software - etapa onde são levantadas a definição dos requisitos de negócios, restrições legais, visão estratégica da fábrica de software 
- Especificação de processos - etapa que se especificam os processos de acordo com os objetivos da fábrica de software

- Modelagem de processos - etapa que se modelam os processos de acordo com alguma linguagem de modelagem de processos, BPMN por exemplo.

- Projeto de processos - define quem, quando e como cada processo modelado será utilizado. É definida a estratégia de implantação, os treinamentos necessários e até adequações de estruturas físicas se necessário for.

- Implantação de processos - transformações do conjunto de informações das etapas anteriores para o domínio real de execução dos processos.

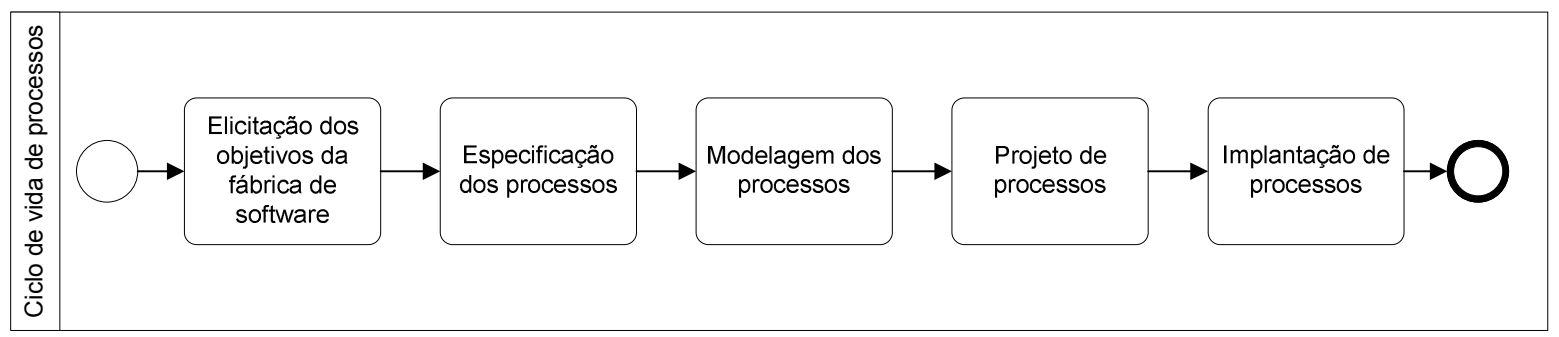

Figura 4 - etapas do modelo conceitual do ciclo de vida de processos (fonte: adaptado de PANIGASSI, 2007)

Esses passos contemplam somente a criação dos processos de uma fábrica de software, porém não é apresentada a criação de processos para um projeto de software específico da fábrica de software.

Do trabalho de Panigassi, é possível entender que somente a ISO 12207 é um metamodelo de processos, pois fornece um modelo geral dos elementos de processos necessários para a criação de uma fábrica. Os modelos como SPICE e CMMI segundo método de Panigassi fornecem os requisitos para a criação de processos. Um entendimento que é mais atual do que o de Derniame apresentado anteriormente. 
O processo proposto pelo autor será um dos conceitos básicos para a criação do método de instanciação, sendo adicionados os modelos da visão processo para representação da fábrica de software.

Para entender a instanciação a seguir define-se o objeto processo e a arquitetura do processo.

\subsection{OBJETO PROCESSO}

As fases propostas por Panigassi foram baseadas no processo de desenvolvimento de software, isso porque o autor cria uma analogia utilizando um objeto computacional do projeto orientado a objetos para representar processos como objetos processos.

Segundo Panigassi um objeto processo representa é composto de métodos e propriedades. Os métodos são as atividades e tarefas do processo, as propriedades do estão compostas pelos atributos do processo.

Esse conceito de objetos processos também é adotado por outros modelos como o SPEM, o BPDM e em trabalhos como Kammer (2000), Taylor (2003), Caetano, Silva e Tribolet (2005) e Holt (2006).

Neste trabalho, os objetos processos são os elementos básicos dos modelos da arquitetura de uma fábrica de software.

\begin{tabular}{|c|}
\hline Objeto processo \\
\hline $\begin{array}{l}\text { sartefato } \\
\text { spapel } \\
\Delta^{\text {recurso }} \\
\text { spolítica }\end{array}$ \\
\hline
\end{tabular}

Figura 5 - Exemplo de um objeto processo

(Fonte: Borsoi 2008) 
A Figura 5 apresenta o conceito de um objeto processo com os elementos que 0 compõem. Na figura é possível observar que o objeto processo tem um nome, tem atributos que são artefato, papel, recurso e política, e também tem operações que são representadas pela ação das atividades que se utiliza de papel, recurso e política para gerar o artefato.

O objeto processo proposto é definido por identidade, atributos e comportamento como nos objetos computacionais. O comportamento são as operações do objeto processo e as ações resultantes de relacionamento entre objetos processos.

As operações são ações das atividades os seus resultados são observados nos recurso, papel, política e artefato.

Os conceitos apresentados neste item serão utilizados para a representação dos processos e são os elementos básicos, estruturais e notacionais, da arquitetura de processos.

Os objetos processos são agrupados e relacionados num modelo denominado de arquitetura de processo como será mostrado a seguir.

\subsection{ARQUITETURA DE PROCESSOS}

A arquitetura de processos representa um conjunto de modelos

Segundo Borsoi (2008) a arquitetura de processos é um conjunto de visões representadas por modelos conceituais de processo, que por sua vez estão constituídos de objetos processos. Esses modelos representam uma estrutura de processos e seus componentes em termos sua composição, comportamentos e relacionamento, de acordo com um domínio e com um contexto.

A arquitetura de processos é uma estrutura com representações estáticas e dinâmicas. 
A arquitetura de processos descrita possui as seguintes visões:

- Estrutural: possui enfoque na estrutura dos processos e de seus componentes. Os modelos são estrutural de processo, de atividade, de recurso, de papel, de artefato e componentes complementares.

- Comportamental: possui enfoque no comportamento do processo e dos seus componentes. O modelo de fluxo de seqüência e de mensagem e os modelos de estados para ator, recurso, atividade, processo e artefato, são os modelos que representam esta visão na arquitetura de processo.

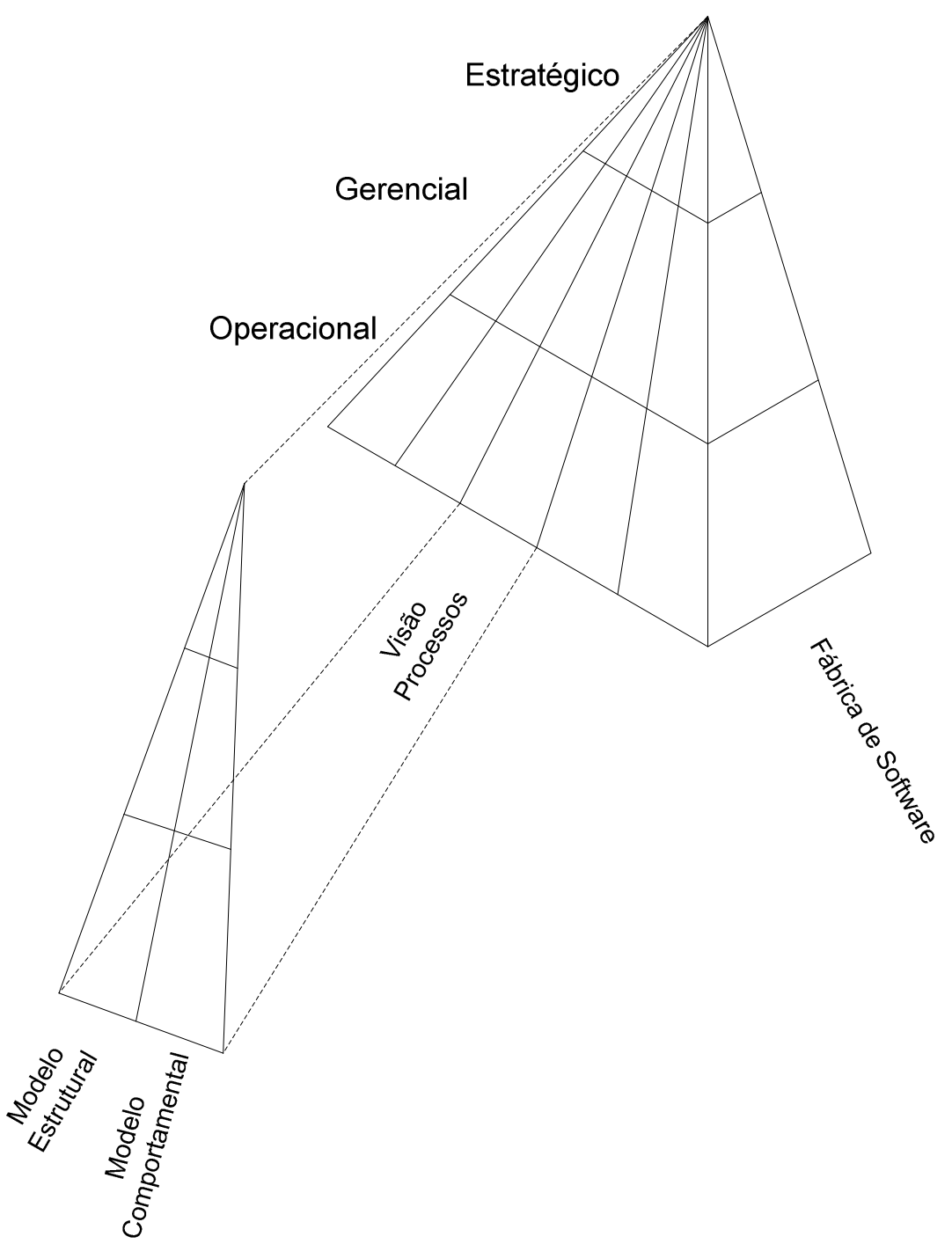

Figura 6 - Modelos da visão processo da Fábrica de software que compõem a arquitetura de processos. 
A Figura 6 contempla a norma IEEE 1471 que apresenta que a descrição de uma arquitetura é organizada por visões e as visões consistem de modelos. Sendo assim, a descrição de cada um dos modelos que constituem a arquitetura de processo são o modelo estrutural e o modelo comportamental.

A Figura 7 apresenta a proposta de relacionamento entre os conceitos fundamentais da arquitetura de processos. Uma arquitetura de processos representa a visão processo da fábrica de software e está constituída por modelos (estrutural e comportamental) que por sua vez são constituídos por diagramas.

\begin{tabular}{|c|c|c|c|c|c|c|}
\hline Arquitetura de & Representa & Visão de processo & Constituída & Modelo & Formado & Diagrama \\
\hline Processos & & & & & por & \\
\hline
\end{tabular}

Figura 7 - Conceitos fundamentais da arquitetura de processos (adaptado de Borsoi, 2008)

A Tabela 2 apresenta esses modelos que representam uma arquitetura de processos em uma fábrica de software, os diagramas de cada modelo, a descrição e a representação.

\begin{tabular}{|c|c|c|c|}
\hline Modelos & Diagrama & Descrição & Representação \\
\hline \multirow[t]{4}{*}{ Estrutural } & $\begin{array}{ll}\text { Descritivo da } \\
\text { atividade }\end{array}$ & $\begin{array}{l}\text { Descreve e documenta } \\
\text { uma atividade do } \\
\text { processo }\end{array}$ & Texto \\
\hline & $\begin{array}{lrr}\text { Diagrama } & & \text { padrão } \\
\text { estrutural } & & \text { do } \\
\text { processo } & \text { e } & \text { da } \\
\text { atividade } & & \\
& & \end{array}$ & $\begin{array}{l}\text { Descreve todos os } \\
\text { elementos que formam } \\
\text { um processo e as } \\
\text { atividades do processo }\end{array}$ & Classes UML \\
\hline & Descritivo do papel & $\begin{array}{l}\text { Documentar e descrever } \\
\text { os papéis dos modelos } \\
\text { de fluxo de seqüência e } \\
\text { de mensagem }\end{array}$ & Texto \\
\hline & $\begin{array}{l}\text { Descritivo } \\
\text { artefato }\end{array}$ & $\begin{array}{l}\text { Documentar e descrever } \\
\text { os artefatos dos modelos } \\
\text { de fluxo de seqüência e }\end{array}$ & Texto \\
\hline
\end{tabular}




\begin{tabular}{|c|c|c|c|}
\hline & & de mensagem & \\
\hline \multirow[t]{5}{*}{ Comportamental } & $\begin{array}{l}\text { Diagrama padrão de } \\
\text { estados do processo }\end{array}$ & $\begin{array}{l}\text { Modelo que descreve os } \\
\text { possíveis estados do } \\
\text { processo }\end{array}$ & Estados UML \\
\hline & $\begin{array}{lr}\text { Diagrama padrão } \\
\text { dos estados das } \\
\text { atividades } \\
\text { processo }\end{array}$ & $\begin{array}{l}\text { Modelo que descreve os } \\
\text { possíveis estados das } \\
\text { atividades } \\
\text { processos }\end{array}$ & Estados UML \\
\hline & $\begin{array}{l}\text { Diagrama padrão } \\
\text { dos estados dos } \\
\text { Atores do processo }\end{array}$ & $\begin{array}{l}\text { Modelo que descreve os } \\
\text { possíveis estados dos } \\
\text { atores dos processos }\end{array}$ & Estados UML \\
\hline & $\begin{array}{l}\text { Diagrama padrão } \\
\text { dos estados dos } \\
\text { Artefatos } \\
\text { processo }\end{array}$ & $\begin{array}{l}\text { Modelo que descreve os } \\
\text { possíveis estados dos } \\
\text { artefatos dos processos }\end{array}$ & Estados UML \\
\hline & $\begin{array}{l}\text { Diagrama padrão de } \\
\text { fluxo de seqüência e } \\
\text { de mensagens entre } \\
\text { atividades }\end{array}$ & $\begin{array}{l}\text { Modelo que apresenta o } \\
\text { fluxo de artefatos e a } \\
\text { troca de mensagens } \\
\text { entre as atividades de } \\
\text { um processo ou entre } \\
\text { processos }\end{array}$ & BPMN \\
\hline
\end{tabular}

Tabela 2 - Relacionamento entre modelos e os diagramas que os compõe

Os detalhes de cada modelo, sua utilização e exemplos serão fornecidos durante a explicação do experimento utilizado neste trabalho. Os objetos processos são os elementos de cada um dos diagramas e são apresentados de diferentes maneiras em cada um dos diagramas do modelo.

A arquitetura de processos possui diferentes níveis de abstração: Arquitetura de referência, arquitetura operacional e arquitetura de projeto como pode ser observado na figura 8.

A arquitetura de referência é gerada a partir de um dos modelos de qualidade como o CMMI, MPS.BR ou ISO 12207 que será trabalhado a partir de modelos para gerar 
os artefatos necessários para instanciação de uma fábrica de software específica. Uma maneira para se gerar arquiteturas de referências pode ser encontrada em Borsoi (2008).

Arquitetura operacional é o resultado da instanciação da arquitetura de referência considerando os requisitos de negócio de uma fábrica de software, ou seja, é a arquitetura de processos representando uma fábrica de software específica.

A arquitetura operacional deverá ser instanciada novamente, mas agora considerando os requisitos específicos de um projeto, gerando a arquitetura de projeto, cuja arquitetura de processos representa os processos que serão executados durante o processo de desenvolvimento de um projeto de software específico projeto.

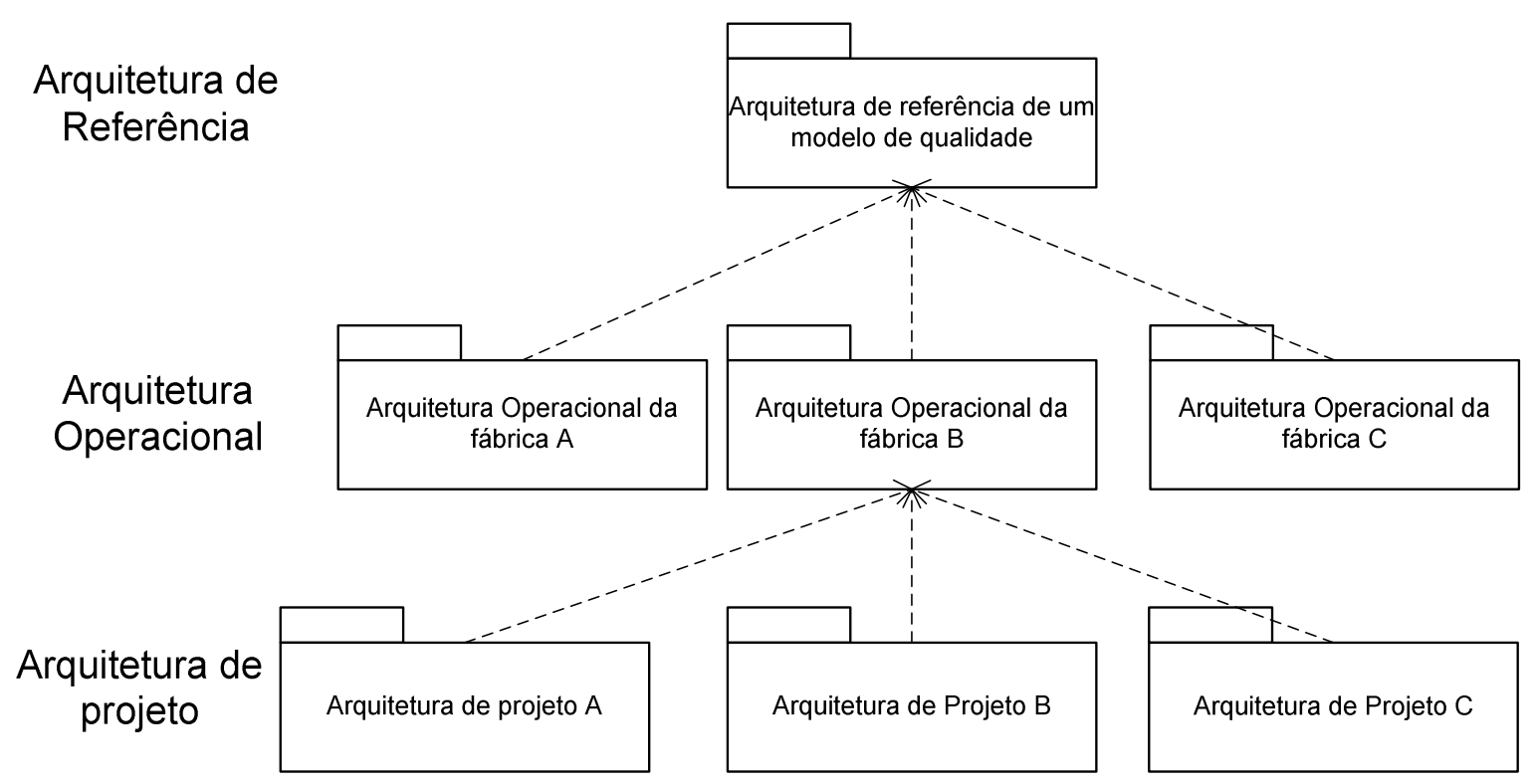

Figura 8 - Níveis de abstração entre arquiteturas de processo

\subsection{INSTANCIAÇÃO}

Instanciar um processo é o ato de transformar um modelo de processos em um modelo executável. É uma categoria especial de customização. (DERMINANE, KABA, WASTELL, 1999) 
A instanciação deve ser realizada, pois os modelos de processos precisam se especializar para levar em consideração requisitos específicos do novo contexto que quer descrever. Durante a instanciação são definidas as variáveis relacionadas com o domínio ou contexto da empresa ou mesmo do projeto específico e essas variáveis analisadas para que se gere um modelo de processo mais especializado. Assim a diferença entre o modelo abstrato e o modelo instanciado é a mudança dos elementos que formam o modelo de processo para atender os requisitos de negócio desse novo ambiente.

O termo instanciação na literatura também é conhecido como "tailoring" que significa fazer sobre medida, assim como um alfaiate (em inglês tailor) faz. Existe uma série de estudos sobre "tailoring", nestes artigos os autores apresentam casos de aplicação de métodos formais e não formais, de aplicação em empresas e em laboratórios, mas independente da forma ou do local onde é aplicado, a definição de tailoring é: realizar o ajuste e/ou particularização dos termos de uma descrição de processo geral para derivar um novo processo aplicável em um ambiente alternativo. O tailoring pode ser aplicado a um modelo de processo geral para geração do processo padrão de uma empresa e também pode ser aplicado para gerar os processos de desenvolvimento em um projeto específico. (PEDREIRA ET AL, 2007; PINO, García e Piattini, 2007; XU, RAMESH, 2008; GINSBERG, M., QUINN, L. 1995)

Neste trabalho o termo instanciação será utilizado dentro do âmbito do conceito de objetos processos e de arquitetura de processos. AFigura 9 apresenta a instanciação do ponto de vista de um objeto processo em três níveis de abstração diferentes. No nível superior, objeto processo da arquitetura de referência, o objeto possui apenas os elementos fundamentais de um objeto processo. Já no nível intermediário após a instanciação para o uso do objeto na fábrica de software este objeto já possui atributos e métodos relevantes ao domínio da fábrica para qual foi instanciado. Já no nível de abstração mais baixo, o objeto foi instanciado do nível intermediário considerando questões do projeto em que este processo será executado. 


\section{Objeto processo da arquitetura de referência}

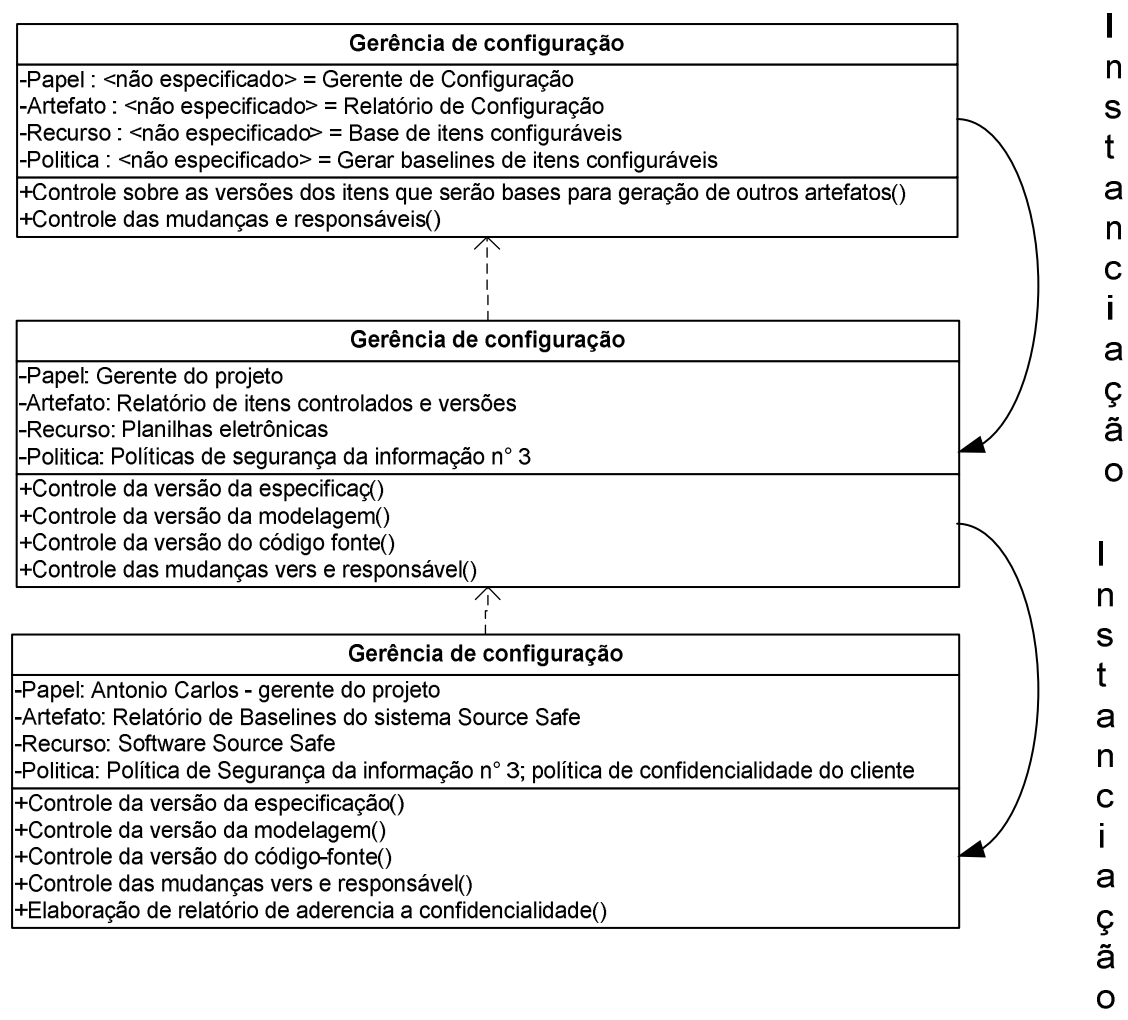

Figura 9 - llustração da instanciação de um objeto processo.

A instanciação refere-se à passagem do objeto processo da arquitetura de referência para o objeto processo da arquitetura operacional. Outra instanciação refere-se à passagem do objeto processo da arquitetura operacional para a arquitetura de projeto.

A figura 10 apresenta a instanciação baseada na arquitetura de processos. No nível intermediário da figura a arquitetura operacional é instanciada a partir da arquitetura de referência do nível superior. Nesta instanciação os requisitos de negócio da empresa foram utilizados para realizar as mudanças na arquitetura de referência. No nível inferior da figura a arquitetura de projeto é instanciada a partir da arquitetura operacional. Esta instanciação é realizada utilizando-se os requisitos de negócio de um projeto de software específico. 


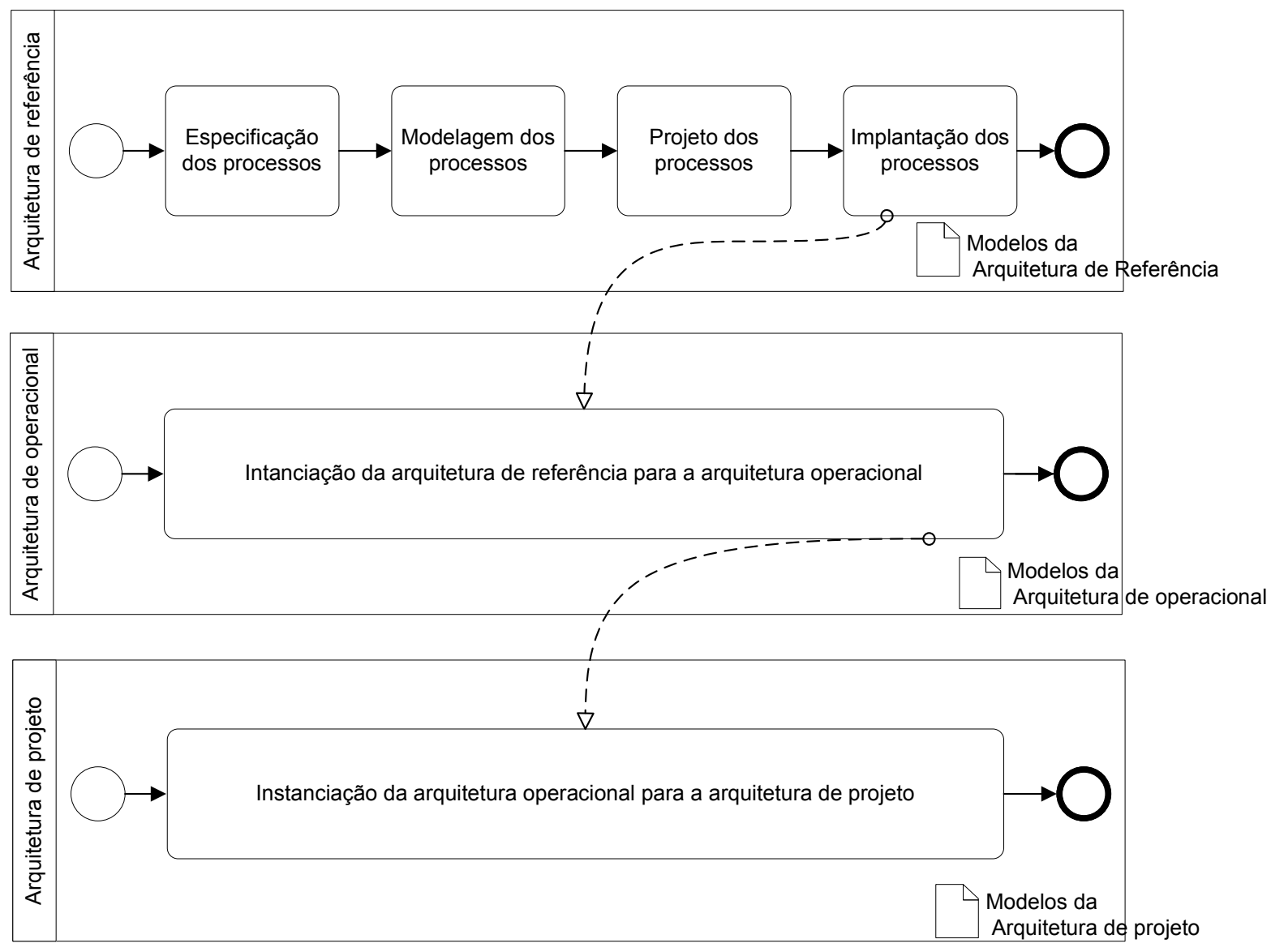

Figura 10 - Projeto de criação de processos

Este é o conceito da instanciação no âmbito da arquitetura de processos, a questão fundamental do trabalho é entender como estas instanciações são realizadas e os elementos envolvidos. 


\section{MÉTODO DE INSTANCIAÇÃO}

O método de instanciação é parte integrante do projeto de criação de processos. A instanciação é a parte do processo em que são detalhados e especializados os elementos dos objetos processos de acordo com as características da empresa e do projeto que serão chamadas de requisitos de negócio. Neste capítulo será detalhado o modelo conceitual do método, seus elementos e considerações para o uso.

\subsection{CONSIDERAÇÕES INICIAIS}

A instanciação pode ser observada pelo entendimento de Borsoi (2008) como sendo a especialização da arquitetura de processos para um ambiente mais específico. Para tal é necessário entender as características deste ambiente específico, ou seja, os requisitos de negócio da empresa ou os requisitos de negócio do projeto específico.

A Figura 11 apresenta esse conceito de instanciação na figura as arquiteturas representadas pelos pacotes estão em níveis de abstração diferentes, o que difere os níveis é o grau de especificidade as arquiteturas que é dada pela instanciação da arquitetura de um nível mais abstrato para um nível abaixo com o contexto mais específico e definido. 


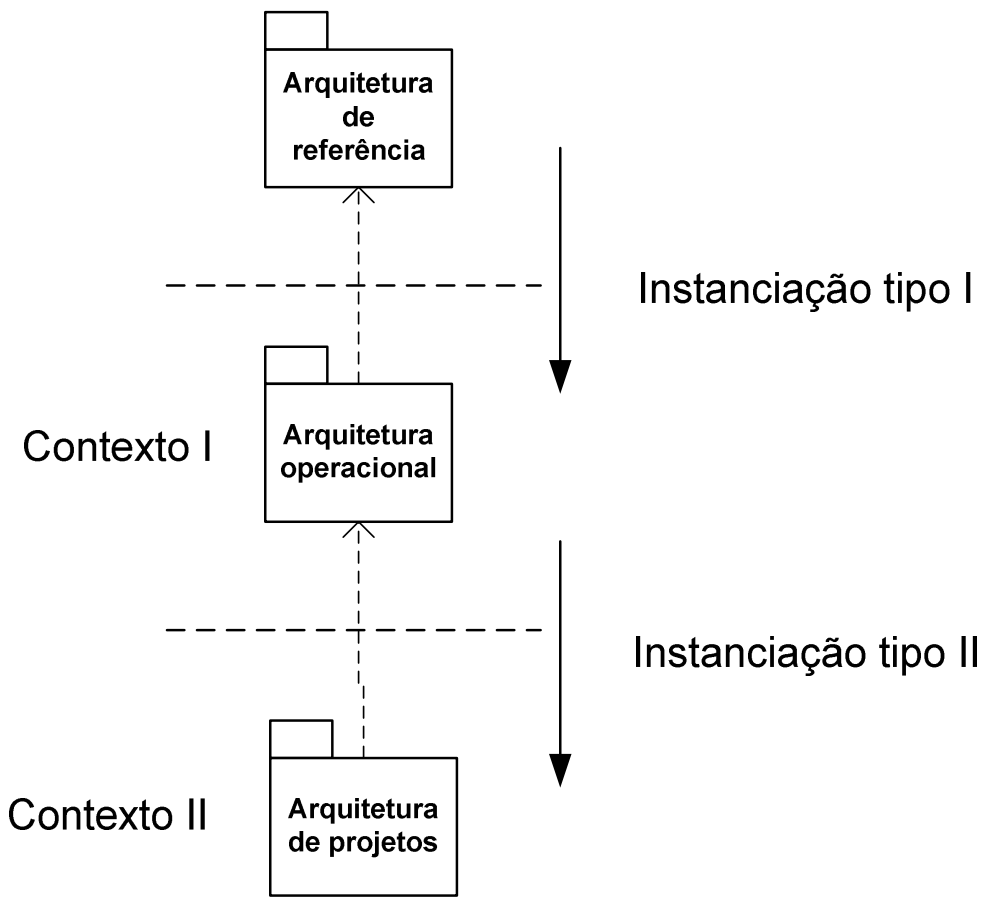

Figura 11 - Instanciação de arquitetura de processos

A sistemática operacional do método de instanciação seguirá a proposta de Panigassi (2007). O método será baseado na analogia ao processo de desenvolvimento do projeto orientado a objetos com as atividades de Especificação dos objetos processos, Modelagem dos objetos processos e Projeto dos objetos processos.

O método de instanciação utilizará as técnicas de tayloring do trabalho de Ginsberg, Quinn (1995), onde se faz uso de mapeamentos entre os elementos de processo e os requisitos de negócio para a tomada de decisão de quais são os processos necessários.

As recomendações de adequação dos processos foram retiradas de $\mathrm{Xu}$, Ramesh (2008), pois estes apresentam um método com as ações que podem ser executadas para adequar cada processo (ex.: adicionar processo, remover processo, incluir atividade ou artefato ou papel). E também se utiliza recomendações práticas do trabalho de Budlong, Szulewski, Ganska (1996).

O método de instanciação proposto foi criado a partir desses trabalhos e será utilizado em dois experimentos que podem ser vistos no capítulo 4. 


\subsection{MODELO CONCEITUAL DO MÉTODO}

O método de instanciação apresenta dois tipos:

- Instanciação tipo I: instanciação que é realizada a partir da arquitetura de uma referência para gerar uma arquitetura operacional. Para tal é necessário analisar os requisitos de negócio da empresa.

- Instanciação tipo II: Instanciação que é realizada a partir de uma arquitetura operacional para gerar uma arquitetura de projeto de software específico. Para tal é necessário analisar os requisitos de negócio específicos do projeto de software.

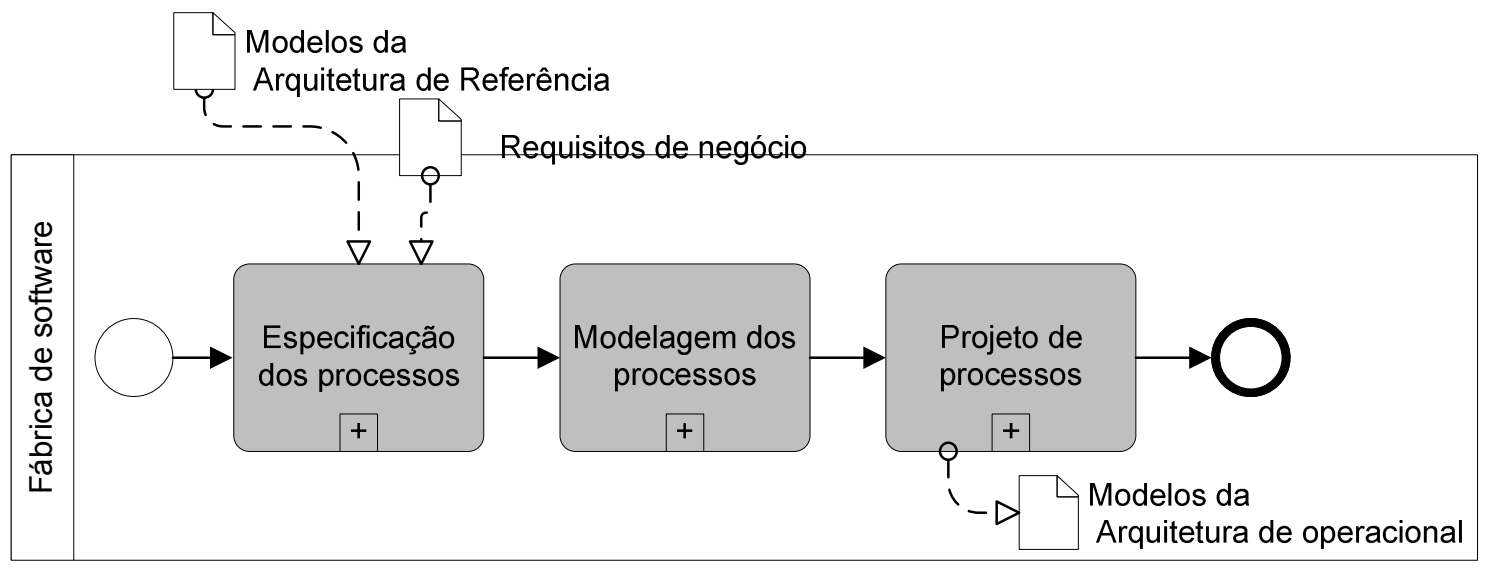

Figura 12 - Modelo conceitual do método de instanciação da instanciação do Tipo I

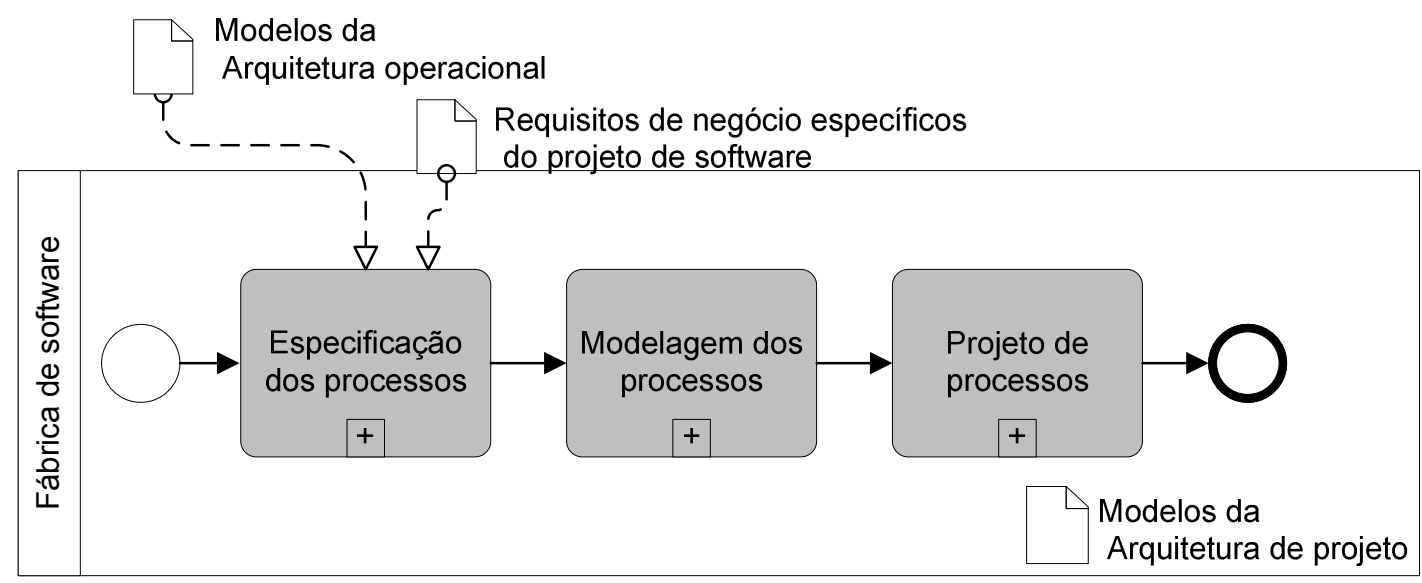

Figura 13 - Modelo conceitual do método de instanciação da instanciação do Tipo II 
A Figura 12 apresenta o modelo conceitual do método de instanciação tipo I e suas etapas.

A Figura 13 foi construída da mesma maneira que a figura anterior, porém trata da instanciação de tipo II do método de instanciação e suas etapas. É importante observar que o produto de saída da instanciação de tipo I, os modelos da arquitetura operacional, é o produto de entrada para as atividades da instanciação de tipo II.

Como será explicado a seguir o método de instanciação está composto das seguintes etapas: Especificação dos processos; Modelagem dos processos; e Projeto dos processos

\subsection{AS ETAPAS DO MÉTODO}

Neste item cada um dos elementos do método será detalhado. Serão explicadas as etapas do método, objetivo, técnica utilizada e o produto gerado em cada etapa.

\subsubsection{Instanciação tipo I}

A seguir são detalhadas as atividades do método de instanciação para instanciação tipo I:

3.3.1.1 Especificação dos processos da fábrica de software

A figura 14 mostra a etapa de especificação da instanciação tipo I 


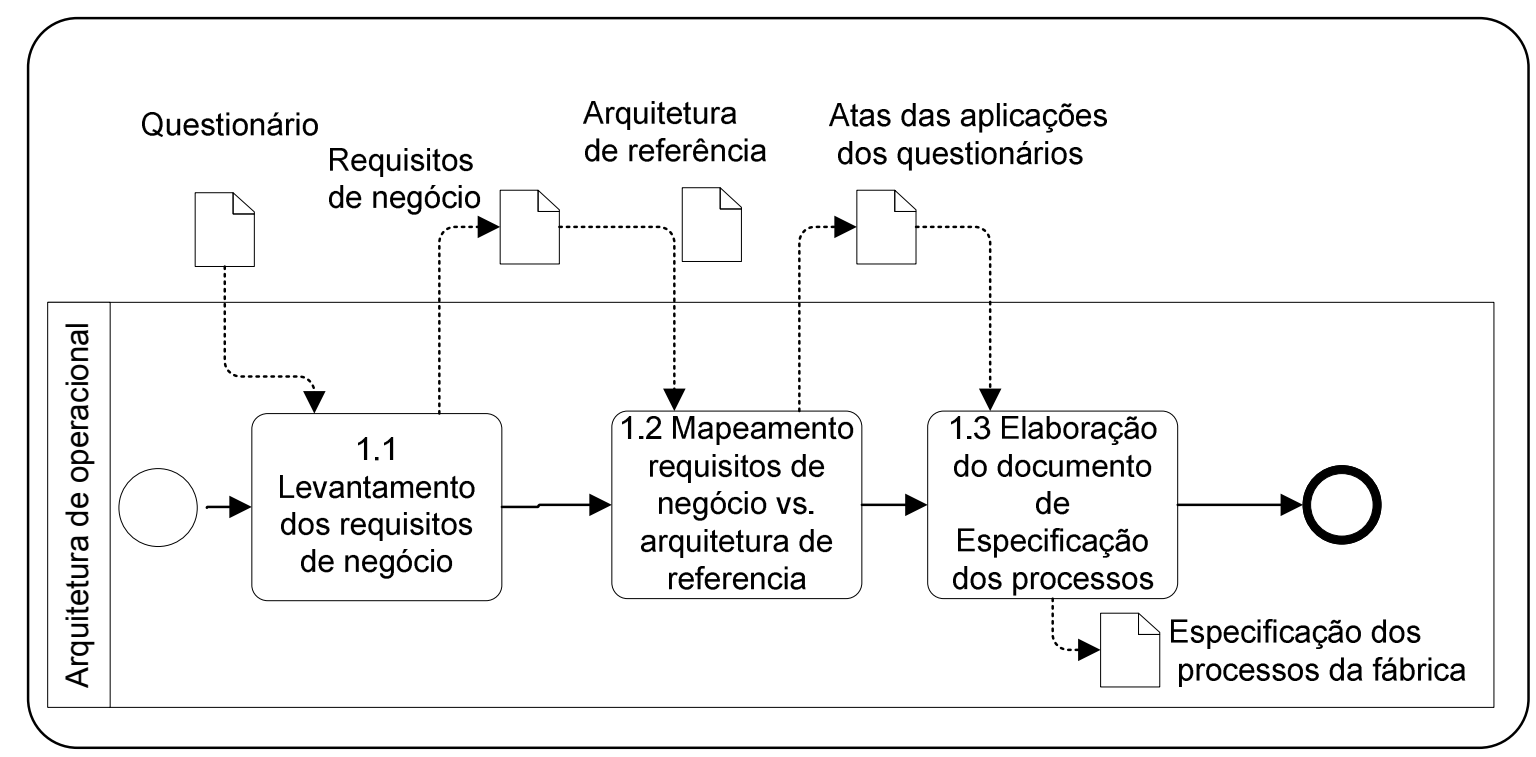

Figura 14 - Detalhamento da 'Especificação dos processos'

Nesta etapa ocorre o detalhamento dos requisitos de negócio relevantes para a criação dos modelos de processos da fábrica. São consideradas as seguintes características do contexto que a fábrica vai atuar: legislação, tecnologias, tipos de sistemas a serem desenvolvidos e metas estratégicas. Além disso, a arquitetura de referência baseada no modelo de qualidade é utilizada para categorizar esses requisitos e entender onde cada um deles tem impacto. Após a identificação dos processos da arquitetura de referência que precisam ser trabalhados, é elaborada a especificação dos novos processos da fábrica.

A atividade 1.1 Levantamento dos requisitos de negócio: é onde o domínio da empresa é capturado através de questionários. Os questionários são montados baseados do padrão ISO/IEC 12207, e a partir da coluna categoria da Tabela 3.

Entrevistas de posse do questionário são realizadas com os membros da equipe de desenvolvimento a fim de se entender a área de atuação da empresa, como ela está dividida, quais tarefas que são realizadas de maneira formal, quais tarefas são realizadas de maneira informal, quais são os principais problemas enfrentados pelos membros da equipe, quais as expectativas de cada um deles diante do projeto de instanciação da fábrica de software. Com quem a equipe se relaciona também é verificado, fornecedores, diretores, clientes, outros departamento como manutenção, marketing. 
A partir das respostas dos questionários os candidatos a requisitos de negócio devem ser identificados. Os candidatos a requisitos devem ser descritos de acordo com as recomendações da ISO 830-1998 IEEE apresentadas a seguir:

a) Corretos: Os requisitos de negócio devem ser corretos e representar o que a fábrica terá que executar

b) Entendimento único: Os requisitos de negócio devem apenas ter uma única interpretação

c) Completos: Os requisitos de negócio devem conter todos os elementos necessários para caracterizá-lo.

d) Consistentes: Devem estar de acordo com os outros documentos a partir do qual foram entendidos.

e) Ordenados por importância: Os requisitos de negócio devem ser ordenados por importância para a instanciação.

f) Verificáveis: Os requisitos de negócio precisam ser verificáveis na fábrica instanciada

g) Modificáveis: Os requisitos de negócio precisam ser estruturados de uma maneira que mudanças neles sejam simples de serem feitas

h) Rastreáveis: Os requisitos de negócio precisam ser rastreáveis durante o processo de instanciação.

Após a descrição dos candidatos a requisitos, estes devem ser classificados com auxílio da Tabela 3. A tabela foi criada a partir das visões do RM-ODP às categorias sugeridas pelo Framework CMM. Cada candidato a requisito é classificado em uma das cinco visões do ODP.

Para cada uma das visões também foram criadas categorias que tem como objetivo servir de sugestão para identificação dos requisitos. Na terceira coluna da tabela devem ser colocados os candidatos a requisitos que se encaixam na categoria de classificação, na tabela apresentada a terceira coluna foi preenchida com alguns exemplos para melhorar a compreensão.

Ainda na tabela na terceira coluna os candidatos a requisitos 1, 2 e 9 estão 
relacionados com a categoria políticas da visão empresa. $\mathrm{O}$ candidato a requisito 4 está relacionado a visão engenharia na categoria tipos de software desenvolvidos. Desta forma, os candidatos a requisitos de negócio 1, 2, 4 e 9 são realmente requisitos de negócio. Os outros candidatos que não puderam ser classificados em nenhuma categoria não estão na tabela e deverão ser descartados.

\begin{tabular}{|c|c|c|}
\hline Visões & Categorias & $\begin{array}{l}\text { Candidatos a } \\
\text { Requisitos }\end{array}$ \\
\hline \multirow{9}{*}{ Empresa } & Políticas & $\begin{array}{l}\text { Candidato a } \text { Requisito } \\
\text { ID1, ID2, ID9 }\end{array}$ \\
\hline & Procedimentos & \\
\hline & Unidades organizacionais & \\
\hline & Características da Empresa & \\
\hline & Papéis corporativos & \\
\hline & Agencias regulamentadoras & \\
\hline & Stakeholders & \\
\hline & Fornecedores & \\
\hline & Mercado & \\
\hline \multirow{3}{*}{ Engenharia } & \begin{tabular}{|lll} 
Tipos de & software \\
desenvolvidos &
\end{tabular} & Candidato a requisito 4 \\
\hline & Recursos utilizados & \\
\hline & Processos & \\
\hline \multirow{2}{*}{ Informação } & Padrões & \\
\hline & Produtos de software & \\
\hline Tecnologia & Tecnologias utilizadas & \\
\hline Computação & Ferramentas & \\
\hline
\end{tabular}

Tabela 3 - Tabela de categorização de requisitos de negócio da fábrica por visões

A seguir a tabela 4 apresenta a definição de cada categoria da tabela 3. 


\begin{tabular}{|c|c|}
\hline Categorias & Descrição da categoria \\
\hline Políticas & $\begin{array}{l}\text { Requisitos de negócio impostos por lei ou } \\
\text { legislação interna ou externa a organização que } \\
\text { controlam limitam ou governam a operação. }\end{array}$ \\
\hline Procedimentos & $\begin{array}{l}\text { Requisitos de negócio ligados ao passo a passo, } \\
\text { ao como fazer. }\end{array}$ \\
\hline Unidades organizacionais & $\begin{array}{l}\text { Requisitos de negócio ligados a distribuição das } \\
\text { unidades na organização. }\end{array}$ \\
\hline Papéis corporativos & $\begin{array}{l}\text { Requisitos de negócio ligados aos papéis existem } \\
\text { na organização }\end{array}$ \\
\hline Agencias regulamentadoras & $\begin{array}{l}\text { Requisitos de negócio impostos por } \\
\text { regulamentações de agencias que controlam o } \\
\text { ramo de atuação. }\end{array}$ \\
\hline Stakeholders & $\begin{array}{l}\text { Requisitos de negócio ligados aos envolvidos no } \\
\text { projeto }\end{array}$ \\
\hline Fornecedores & Requisitos de negócio impostos por fornecedores \\
\hline Mercado & $\begin{array}{l}\text { Requisitos de negócio impostos por práticas de } \\
\text { mercado }\end{array}$ \\
\hline $\begin{array}{lll}\text { Tipos de } & \text { software } \\
\text { desenvolvidos } & \end{array}$ & $\begin{array}{l}\text { Requisitos de negócio ligados ao tipo de software } \\
\text { que se desenvolve }\end{array}$ \\
\hline Recursos utilizados & $\begin{array}{l}\text { Requisitos de negócio ligados ao tipo dos recursos } \\
\text { utilizados como forma de aquisição, licenças etc. }\end{array}$ \\
\hline Processos & $\begin{array}{l}\text { Requisitos de negócio ligados aos processos } \\
\text { executados pela organização }\end{array}$ \\
\hline Padrões & $\begin{array}{l}\text { Requisitos de negócio ligados aos padrões } \\
\text { utilizados pela organização. }\end{array}$ \\
\hline Tecnologias utilizadas & $\begin{array}{l}\text { Requisitos de negócio ligados a tecnologias } \\
\text { utilizadas. (mudança tecnológica, curva de } \\
\text { aprendizado) }\end{array}$ \\
\hline Ferramentas & $\begin{array}{l}\text { Requisitos de negócio } \\
\text { ferramentas utilizadas na } \\
\text { execução da operação. }\end{array}$ \\
\hline
\end{tabular}


Ao fim da atividade 1.1 têm-se os requisitos de negócio descritos de maneira textual e numerados de maneira que sua identificação seja única.

A atividade seguinte, 1.2 Mapeamento dos requisitos de negócio versus arquitetura de referência, tem arquitetura de referência baseada num modelo de qualidade como um dos produtos de entrada. Essa arquitetura é trabalhada a fim se identificar as alterações dos elementos de processo segundo os requisitos de negócio.

\begin{tabular}{|l|l|l|l|}
\hline $\begin{array}{l}\text { Id dos Requisitos de } \\
\text { negócio do projeto }\end{array}$ & $\begin{array}{l}\text { Elementos do processosos } \\
\text { impactados } \\
\text { impactados }\end{array}$ & $\begin{array}{l}\text { Aça ser } \\
\text { executada }\end{array}$ \\
\hline & & & \\
\hline & & & \\
\hline & & & \\
\hline
\end{tabular}

Tabela 4 - matriz de requisitos de negócio e impacto nos objetos processos

$\mathrm{Na}$ Tabela 4 todos os requisitos de negócio do projeto devem ser inseridos na primeira coluna. $\mathrm{Na}$ segunda coluna devem ser colocados os processos da arquitetura de referência que tem relação com o requisito de negócio que está sendo analisado.

A terceira coluna apresenta o elemento específico do processo impactado devem ser identificados por meio do uso da arquitetura de processos de referência os processos e os elementos desses processos que os requisitos de negócio impactam.

Na mesma tabela a quarta coluna ao lado de cada elemento identificado deve ser preenchida com a ação a ser executada para adequação deste objeto processo da arquitetura de referência ao requisito de negócio. Os objetos processos podem ser adequados das seguintes maneiras:

- Adicionados - quando devido ao requisito de negócio é necessário criar um elemento do objeto processo na arquitetura de processos de operacional, pois este não existia na arquitetura de processos referência;

- Removidos - quando devido ao requisito de negócio é necessário retirar um 
elemento do objeto processo que existia na arquitetura de processos de referência;

- Reduzidos - quando devido ao requisito de negócio é necessário diminuir escopo dos elementos de um objeto processo da arquitetura de processos de referência;

- Expandidos - quando devido ao requisito de negócio é necessário aumentar o escopo dos elementos de um objeto processos da arquitetura referência;

- Substituídos - quando devido ao requisito de negócio é necessário substituir algum elemento do objeto processo por outro já existente, por exemplo, a substituição de um documento da arquitetura de referência por um documento com o conteúdo exigido pelo cliente; e

- Redefinidos - quando devido ao requisito de negócio é necessário redefinir os elementos de um objeto processo.

$\mathrm{Na}$ etapa 1.3 Elaboração do documento de especificação dos processos as alterações nos objetos processos e/ou os elementos dos objetos processos são detalhadas de maneira textual. O descritivo das atividades, dos papéis e dos artefatos é inserido neste documento como apresentado nas figuras 16, 17 e 18

De posse dos produtos gerados nessa etapa pode-se iniciar a modelagem dos processos para o projeto.

\begin{tabular}{|l|l|}
\hline Nome da atividade: & Nome da atividade que será descrita \\
\hline Ator: & Papel responsável pela execução da atividade \\
\hline Tipo: & $\begin{array}{l}\text { Tipo serve para organizar as atividades em } \\
\text { grupos }\end{array}$ \\
\hline Descrição: & Detalhamento sobre a definição atividade \\
\hline Meta: & $\begin{array}{l}\text { Meta a ser atingida durante a execução da } \\
\text { atividade }\end{array}$ \\
\hline
\end{tabular}




\begin{tabular}{|l|l|} 
Pré-condições: & Condições necessárias para início da atividade \\
\hline Artefato entrada: & Artefato utilizado durante a execução da atividade \\
\hline Tarefas: & Detalhamento passo a passo da atividade \\
\hline Recursos: & Recursos necessários para execução da atividade \\
\hline Habilidades: & $\begin{array}{l}\text { Habilidades necessárias ao ator para executar a } \\
\text { atividade }\end{array}$ \\
\hline Artefato saída: & Artefato resultante após a execução das tarefas \\
\hline Controle: & $\begin{array}{l}\text { Restrição à realização da atividade, por exemplo, } \\
\text { referentes a políticas ou legislação. }\end{array}$ \\
\hline Métricas: & $\begin{array}{l}\text { Medições que serão realizadas para avaliar o } \\
\text { desempenho da atividade }\end{array}$ \\
\hline
\end{tabular}

Figura 15 - Diagrama descritivo da atividade (fonte: Adaptado de Borsoi, 2008)

\begin{tabular}{|l|l|}
\hline Nome & Nome do papel \\
\hline Descrição & Detalhamento sobre o papel \\
\hline
\end{tabular}

Figura 16 - Diagrama descritivo do papel (fonte: Adaptado de Borsoi, 2008)

\begin{tabular}{|l|l|}
\hline Nome & Nome do artefato \\
\hline Descrição & Detalhamento sobre o artefato \\
\hline Tipo & Tipo que classifica os artefatos em grupos \\
\hline Versão & Versão atual do artefato \\
\hline Proprietário & Pessoa responsável pela criação do artefato \\
\hline Política & As políticas que o artefato está sujeito \\
\hline Modelo & $\begin{array}{l}\text { Template, orientações ou critérios para } \\
\text { produzir o artefato }\end{array}$ \\
\hline Composto & $\begin{array}{l}\text { Indicações de dos artefatos que compões o } \\
\text { artefato descrito }\end{array}$ \\
\hline Derivado & $\begin{array}{l}\text { Indicação do artefato que origina o artefato } \\
\text { descrito }\end{array}$ \\
\hline
\end{tabular}

Figura 17 - Diagrama descritivo do artefato (fonte: Adaptado de Borsoi, 2008) 
3.3.1.2 Modelagem dos processos da fábrica

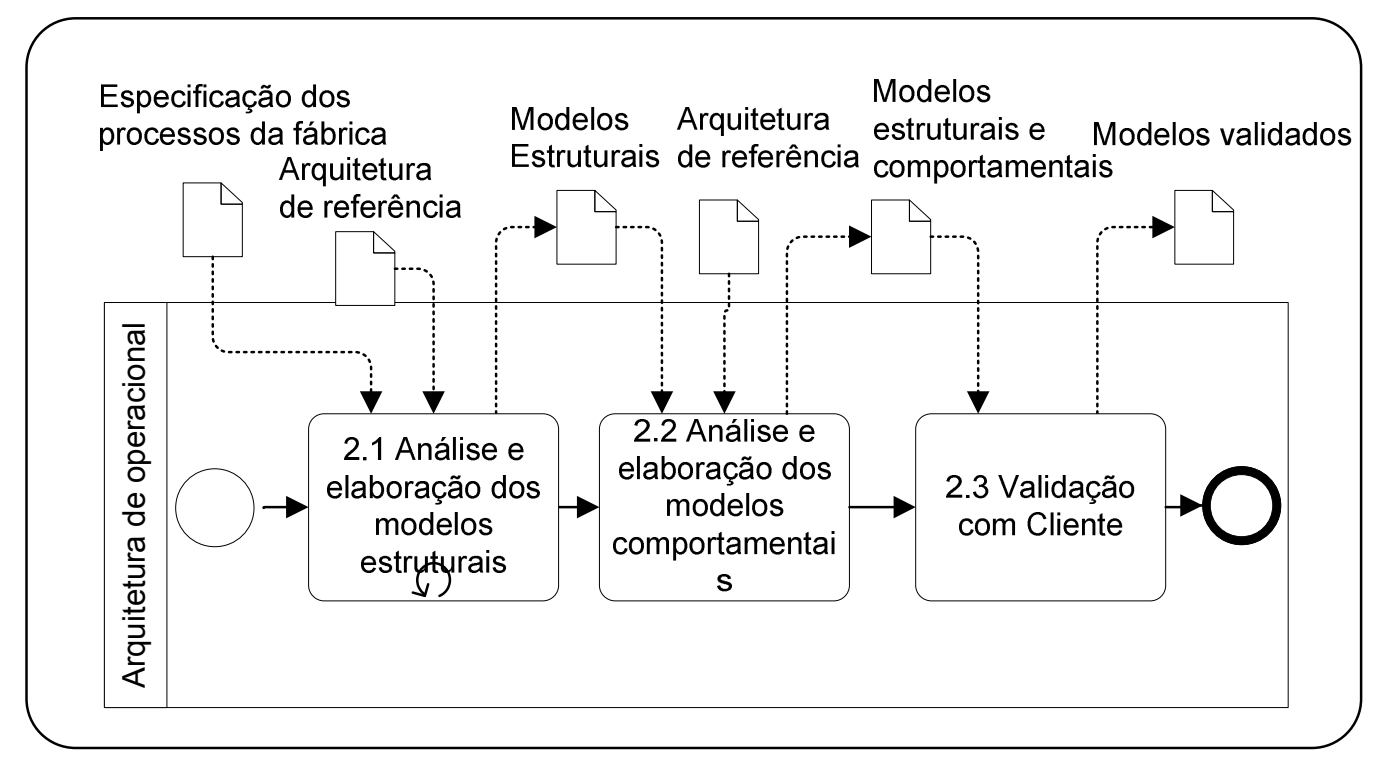

Figura 18 - Diagrama BPMN do detalhamento da atividade '2. Modelagem dos processos da fábrica de software' do método de instanciação.

Nesta etapa são modelados os processos de acordo com os requisitos especificados na fase anterior e são analisadas os relacionamentos, dependências e limitações dos processos. Os modelos de processos são o modelo estrutural e o modelo comportamental:

Modelo Estrutural contém a estrutura do objeto processo e dos seus elementos. $\mathrm{O}$ diagrama deste modelo é:

- Diagrama estrutural do processo e da atividade - Diagrama que define todos os elementos que compõem um processo. Como se mostra na Figura 19.

$\mathrm{Na}$ atividade 2.1 Análise e elaboração dos modelos estruturais são criados todos os diagramas do modelo estrutural. 


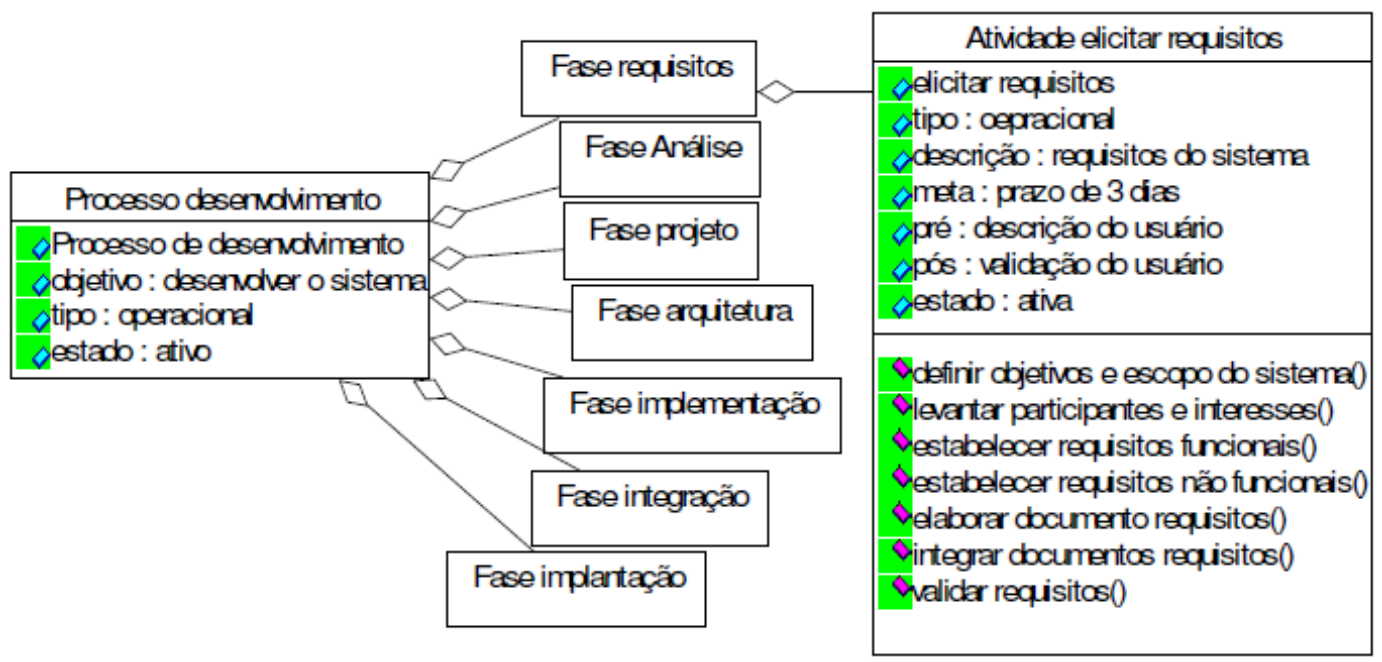

Figura 19 - Exemplo do diagrama estrutural do processo e da atividade

É importante que após cada mudança realizada nos diagramas se verifique a consistência com os outros diagramas e dos objetos processos.

A Figura 20 apresenta um modelo para a consistência que contém os relacionamentos entre os elementos essenciais do objeto processo. Deve-se estar atento a qualquer alteração nestes elementos, pois estas podem criar objetos processos inconsistentes. Ou seja, como pode ser observado na Figura 20 uma alteração em um artefato ou papel pode impactar uma ou mais atividades, no pior caso fazendo com que a atividade fique incompleta ou não possa ser realizada.

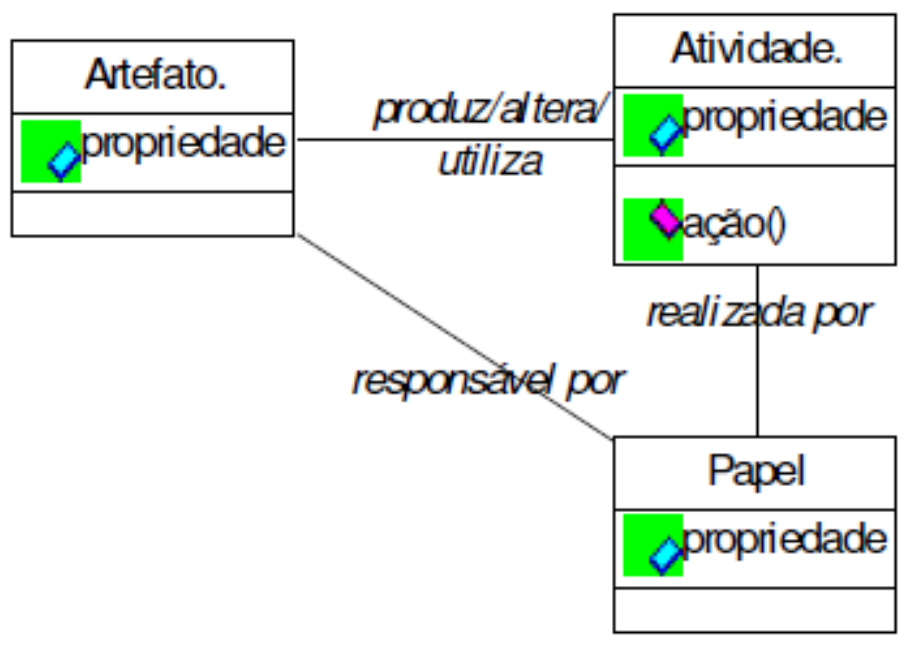

Figura 20 - Componentes essenciais do objeto processo (fonte: Borsoi,2008) 
$\mathrm{Na}$ atividade 2.2 Elaboração e análise do modelo comportamental são elaborados os diagramas do modelo comportamental. Os diagramas do modelo comportamental devem ser adaptados em cada um dos modelos segundo a especificação, de forma detalhada e objetiva (fluxos de mensagens, seqüência de atividades e estados inseridos, removidos, expandidos, suprimidos, refinados ou substituídos).

Modelo Comportamental representa os aspectos dinâmicos do processo e dos seus componentes, como estados e fluxos entre atividades. Os diagramas desse modelo são:

- Diagrama de estados do processo - Descreve os possíveis estados de cada processo. Figura 21

- Diagrama dos estados das atividades do processo - Descreve os possíveis estados de cada atividade de cada processo. Figura 22

- Diagrama dos estados dos atores do processo - Descreve os possíveis estados dos atores do processo. Figura 23

- Diagrama dos estados dos artefatos do processo. Figura 24

- Diagrama de fluxo de seqüência e de mensagens entre atividades. Figura 25 


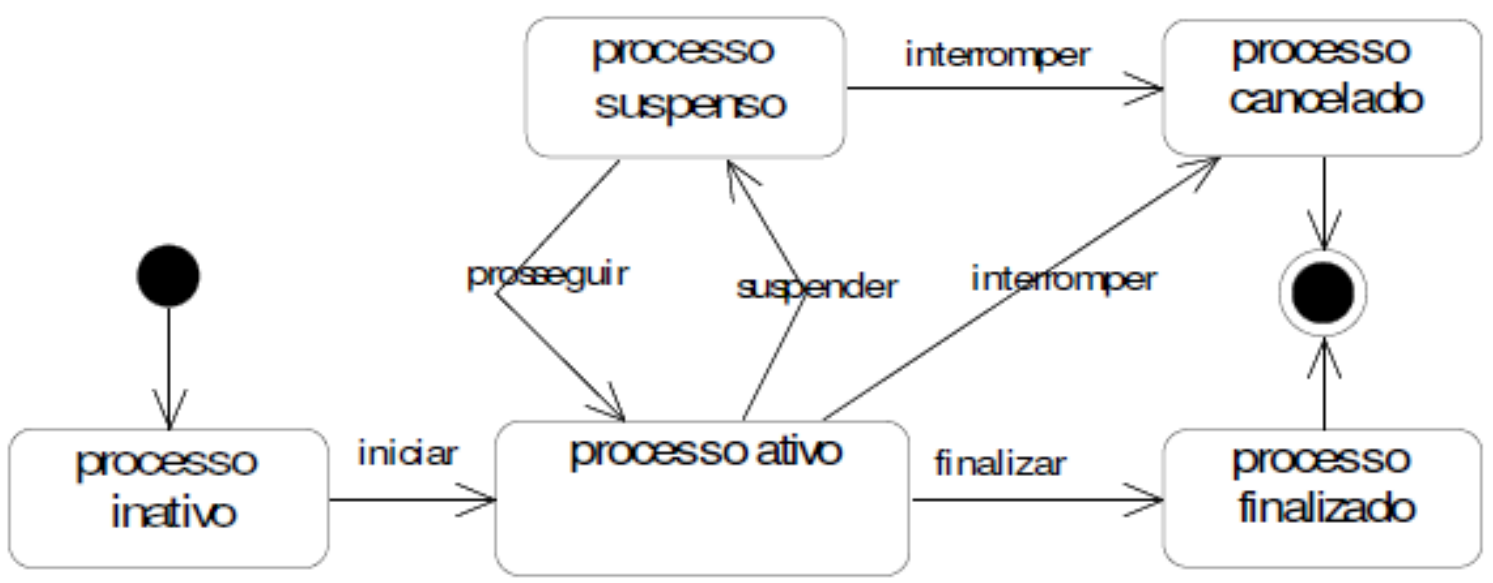

Figura 21 - Diagrama de estados do processo (fonte: Borsoi, 2008)

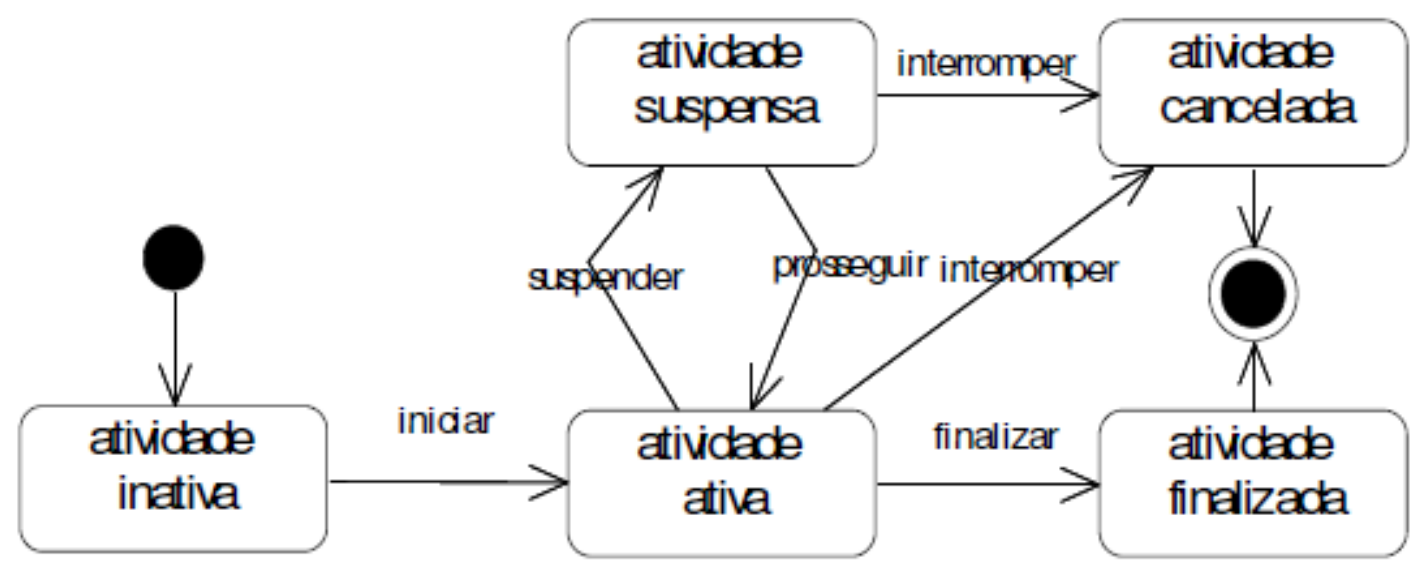

Figura 22 - Diagrama de estados da atividade (fonte: Borsoi, 2008)

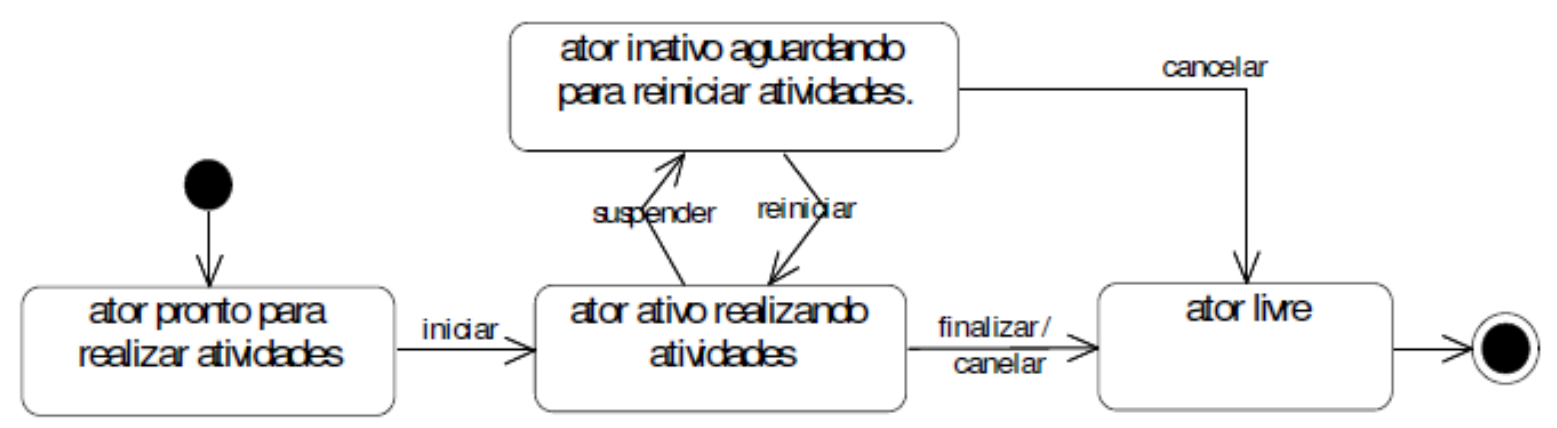

Figura 23 - Diagrama de estados dos atores (fonte: Borsoi, 2008) 


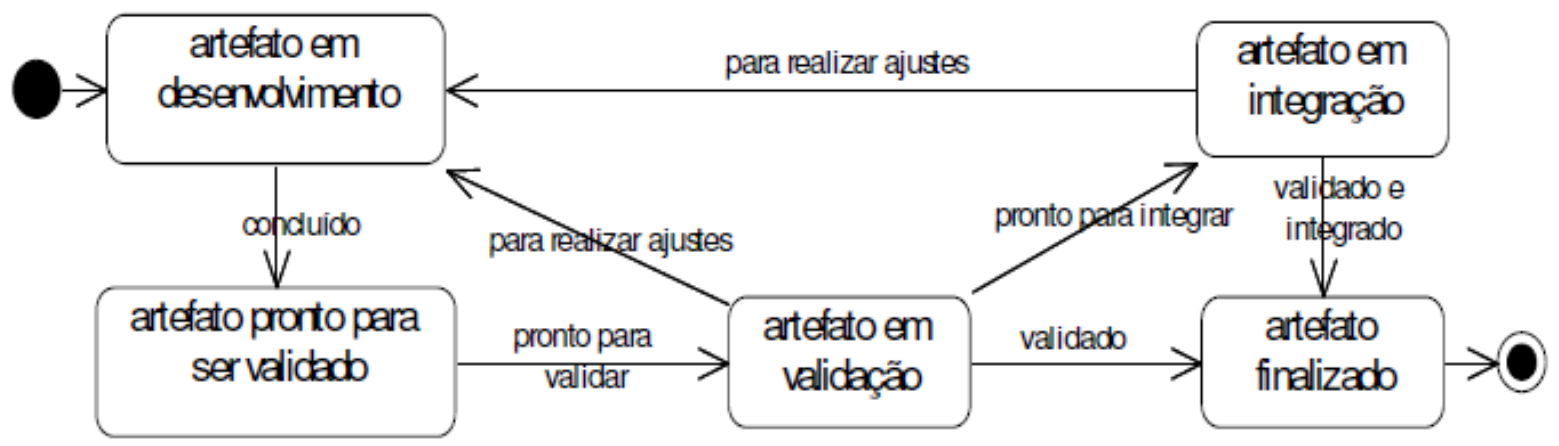

Figura 24 - Diagrama de estados do artefato (fonte: Borsoi, 2008)

Processo de Desenvolvimento (PD)
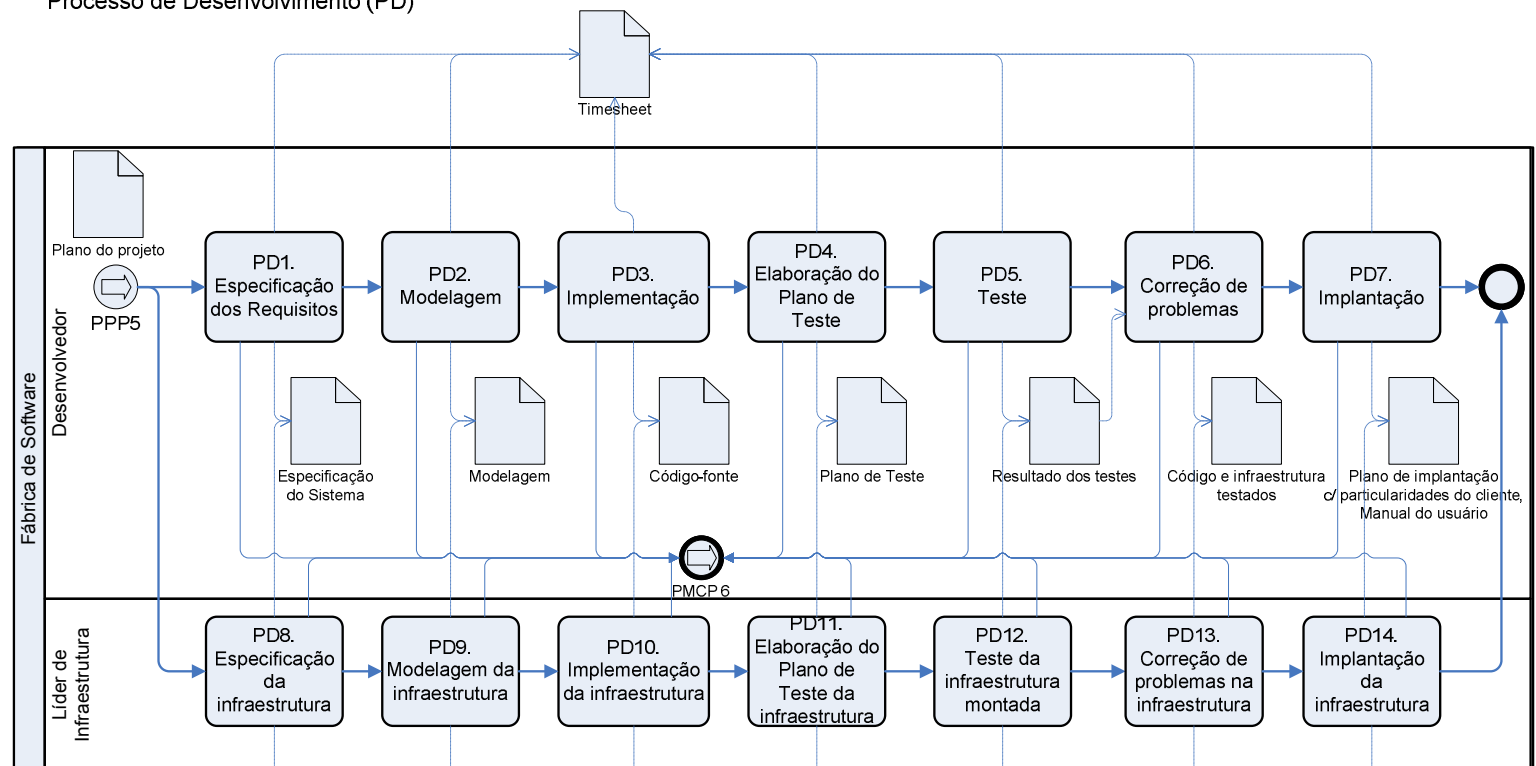

Figura 25 - Diagrama de fluxo de seqüência e de mensagens entre atividades

A Figura 26 traz os componentes envolvidos nos fluxos de seqüência e de mensagem. É fundamental que qualquer alteração em algum desses componentes seja analisada de forma criteriosa quanto ao impacto nos demais objetos processos para não se causar inconsistências. 
Por exemplo, se a necessidade de um artefato é descartada, as atividades que produzem, alteram ou utilizam este artefato devem ser verificadas para decidir se poderão ser descartadas ou deverão ser modificadas. Pela Figura 26 deverá verificar os fluxos que utilizam esse artefato, tomando a decisão de alterá-los, caso não seja possível fica evidente que o artefato não poderá ser descartado do processo do projeto.

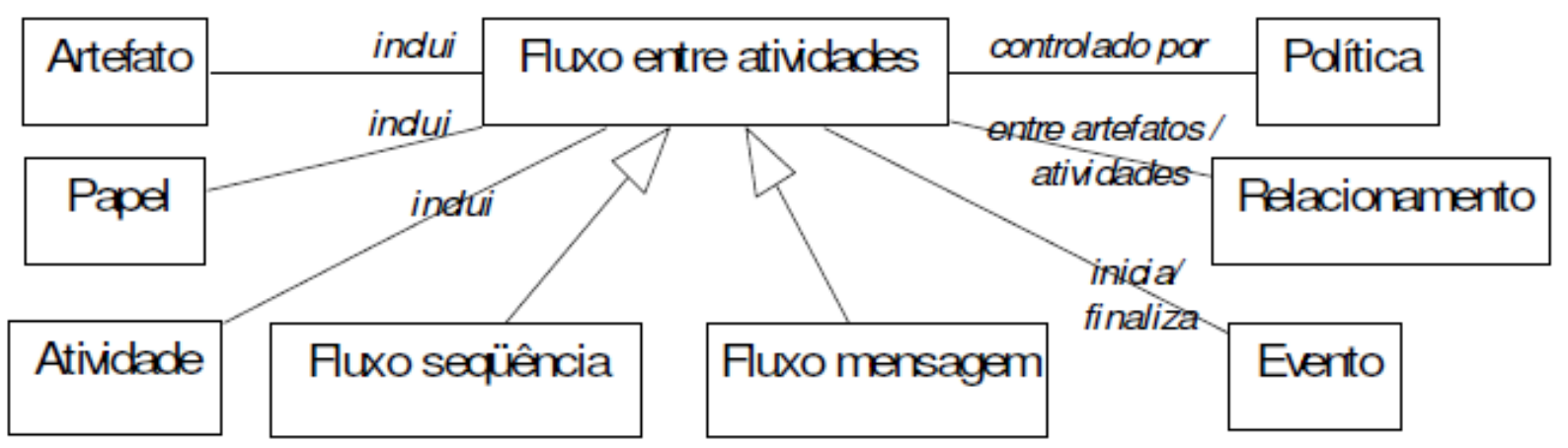

Figura 26 - Conceitos para representar fluxos de seqüência e de mensagem (fonte: BORSOI, 2008)

A etapa 2.3 Validação com a equipe de desenvolvimento evidencia a importância da validação para garantia que o processo de negócio esteja aderente ao novo modelo, ou seja, que se tenha no novo processo as características da empresa e as melhorias desejadas. Nesta validação primeiramente devem ser apresentados os requisitos de negócio levantados em seguida a especificação, assim o cliente fica preparado para validar os diagramas. Em seguida são apresentados os modelos a partir do planejamento do projeto, passando para o processo de desenvolvimento e então para a gerência, para facilitar o entendimento. Todas as considerações feitas devem ser anotadas e discutidas, se necessário os modelos devem ser atualizados. 


\subsubsection{Projeto dos Processos}

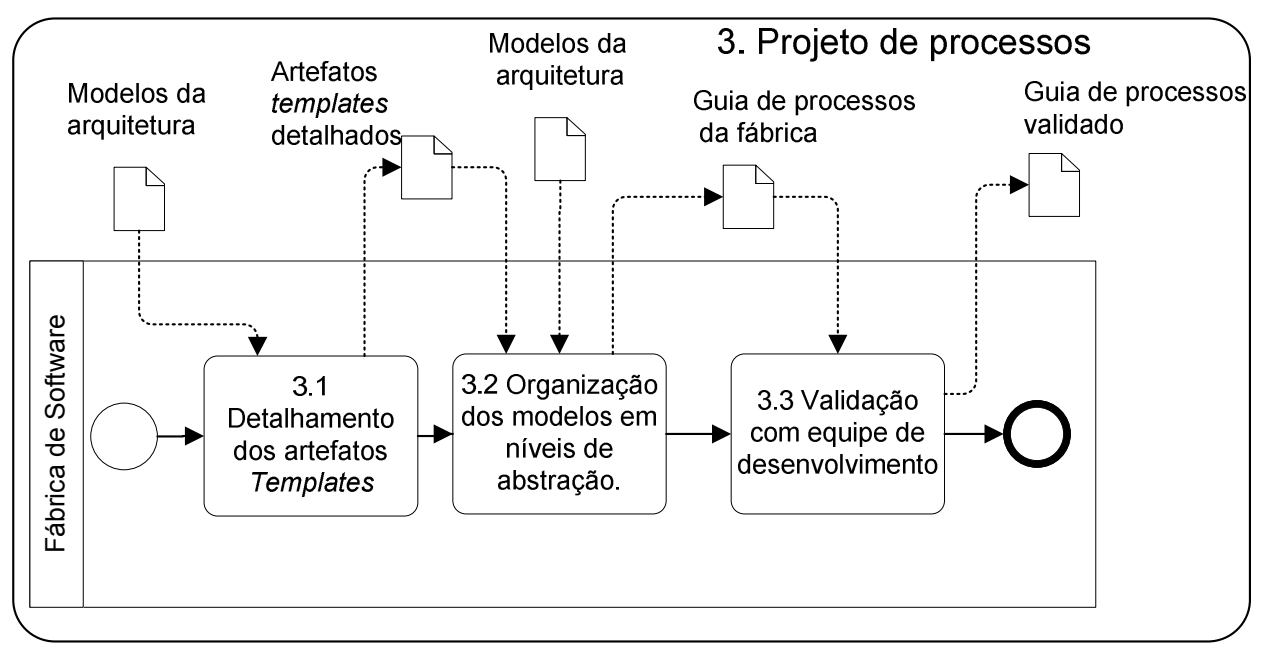

Figura 27 - Diagrama BPMN do detalhamento da atividade '3. Projeto dos processos da fábrica de software' do método de instanciação.

Nessa etapa devem ser detalhados os conteúdos e formatos dos templates dos artefatos, definidas as configurações dos recursos e homogeneizados os nomes respeitando convenções de nomes e eventuais utilizações de prefixos.

A atividade 3.1 Detalhamento dos templates dos artefatos apresentada na Figura 27 utiliza os modelos da arquitetura criados na etapa 2 Modelagem do processos para criar os templates e definir os formatos dos artefatos da fábrica de software. $O$ conteúdo dos templates deve satisfazer os processos que têm os artefatos como entrada ou saída.

$\mathrm{Na}$ atividade 3.2 Organização dos modelos em níveis de abstração os modelos estruturais e comportamentais são detalhados, a nomenclatura é ajustada, os prefixos são criados, uma classificação entre os processos é definida utilizando o elemento tipo do diagrama de descrição da atividade para facilitar o entendimento (ex.: atividades do tipo gerenciais e atividades operacionais, ou, atividades principais e atividades de suporte, ou, atividades de desenvolvimento de componentes e atividades de desenvolvimento de software).

Ainda na atividade 3 os modelos devem ser organizados de preferência em uma ferramenta ou documentos que permitam a navegação entre os modelos e seus 
detalhamentos, que sejam visuais, assim como, por exemplo, páginas html que podem conter links, figuras e acesso a outros documentos, não é uma ferramenta de execução de processos, é uma ferramenta que permita a fácil navegação entre os diversos modelos de processos da fábrica. Desta maneira, o produto criado nesta etapa do método de instanciação é um conjunto de modelos de processos e detalhamento destes modelos que formam a arquitetura de processo. Este produto é o elemento central para a apresentação e para o entendimento dos processos da fábrica de software pela equipe de desenvolvimento que executará os processos.

$\mathrm{Na}$ etapa 3.3 Validação pela equipe de desenvolvimento a arquitetura gerada deve ser validada. Novamente são apresentados os requisitos de negócio a especificação para então ser apresentada a arquitetura de processos da fábrica de software. A validação deve ser realizada apresentando todos os modelos de processo de maneira detalhada e os artefatos, explicando-os detalhadamente. Todas as recomendações, sugestões apontadas ou alterações solicitadas devem ser analisadas e, se necessário, a arquitetura de processos do projeto deve ser ajustada, sempre observando os relacionamentos, interdependência entre processos para não se criar inconsistências. Por fim, a arquitetura resultante que contem todos os modelos de processo organizados, classificados e também possui 0 detalhamento dos artefatos deve ser apresenta a equipe para início do uso.

A implantação da arquitetura de processos não faz parte do método de instanciação proposto neste trabalho, mas é a etapa seguinte a ser realizada para se colocar em "funcionamento" a arquitetura de processos instanciada para a fábrica de software.

\subsubsection{Instanciação tipo II}

Esta etapa do método é responsável pela instanciação da arquitetura de processos operacional para a arquitetura de processos do projeto.

O método de instanciação do tipo II é o mesmo da instanciação do tipo. Porém algumas considerações devem ser feitas, pois a instanciação de tipo I deve ter sido executada e a arquitetura operacional gerada, caso contrário não é possível realizar a instanciação de tipo II. 
Os requisitos de negócio devem ser os requisitos específicos do projeto, então a etapa 1.1 Levantamento do questionário será reestruturada para levantar esses requisitos.

Todos os locais onde se lê arquitetura de referência no método de instanciação de tipo I, deverá se ler arquitetura operacional para instanciação do tipo II. Isso ocorre, pois o objetivo da instanciação de tipo II é instanciar a arquitetura operacional, que possui os modelos dos processos da fábrica, para o contexto do projeto de software a ser produzido que possui características específicas que afetam a maneira de desenvolver.

Etapa 1.1 Levantamento de requisitos de negócio, como foi comentado anteriormente essa atividade foi adaptada para uma melhor aderência ao levantamento dos requisitos de negócio do projeto. Nesta etapa um questionário deve ser elaborado as seguintes perguntas (XENG, RAMESH 2008):

- Objetivos do software - Quais são os resultados (funcional, financeiro, imagem, etc.) que o software deve atingir

- Objetivos do processo - Quais são os resultados que o processo de desenvolvimento do software deve obter. (comunicação eficiente dos envolvidos, controle de qualidade, gestão de riscos e planos de contingência, etc.)

- Características do software - Requisitos do software a ser desenvolvido

- Características da equipe - Habilidades técnicas e de relacionamento de cada um dos membros da equipe

- Características dos stakeholders do projeto - Características como comprometimento, qualificação, horas dedicadas ao projeto, responsabilidades de cada envolvido no projeto. 
Estes requisitos devem ser classificados nas cinco visões do ODP da mesma maneira que os requisitos de negócio da fábrica de software. Desta maneira a Tabela 3 - Tabela de categorização de requisitos de negócio da fábrica por visões, apresentada no item anterior, foi atualizada gerando a Tabela 5 apresenta a seguir:

\begin{tabular}{|c|c|c|}
\hline Visões & Categorias & $\begin{array}{l}\text { Candidatos a } \\
\text { Requisitos }\end{array}$ \\
\hline \multirow{8}{*}{ Empresa } & \multirow{2}{*}{\begin{tabular}{|l|} 
Políticas do projeto \\
Procedimentos do projeto
\end{tabular}} & $\begin{array}{l}\text { Candidato a Requisito } \\
1,2,9\end{array}$ \\
\hline & & \\
\hline & \multicolumn{2}{|l|}{$\begin{array}{l}\text { Unidades organizacionais } \\
\text { envolvidas no projeto }\end{array}$} \\
\hline & \multicolumn{2}{|l|}{ Papéis corporativos do projeto } \\
\hline & \multicolumn{2}{|l|}{\begin{tabular}{|l|} 
Agencias regulamentadoras \\
ligadas ao projeto
\end{tabular}} \\
\hline & \multicolumn{2}{|l|}{ Stakeholders do projeto } \\
\hline & \multicolumn{2}{|l|}{ Fornecedores do projeto } \\
\hline & \multicolumn{2}{|l|}{ Mercado do projeto } \\
\hline \multirow{3}{*}{ Engenharia } & Software desenvolvido & Candidato a requisito 4 \\
\hline & \multicolumn{2}{|l|}{ Recursos utilizados no projeto } \\
\hline & \multicolumn{2}{|l|}{ Processos do projeto } \\
\hline \multirow[b]{2}{*}{ Informação } & \multicolumn{2}{|l|}{ Padrões do projeto } \\
\hline & \multicolumn{2}{|l|}{\begin{tabular}{|llll}
$\begin{array}{l}\text { Produtos de software do } \\
\text { projeto }\end{array}$ & \\
\end{tabular}} \\
\hline Tecnologia & \multicolumn{2}{|l|}{$\begin{array}{l}\text { Tecnologias utilizadas no } \\
\text { projeto }\end{array}$} \\
\hline Computação & Ferramentas do projeto & \\
\hline
\end{tabular}

Tabela 5 - Categorização dos requisitos de negócio do projeto por visões

Após essa categorização o método de instanciação tipo II segue da mesma maneira da instanciação tipo I.

O método de instanciação do tipo I será avaliada em dois experimentos como é proposto no seguinte capítulo. 
A instanciação do tipo II não está dentro do escopo da aplicação experimental.

\subsection{CONSIDERAÇÕES SOBRE APLICAÇÃO DO MÉTODO}

O conhecimento de processos de desenvolvimento de software e modelos de qualidade são importantes para o responsável pela utilização do método, pois são muitas variáveis e muitas decisões que precisam ser tomadas e estas devem ter um forte embasamento em engenharia de software aliados a uma experiência prática de projetos de software.

O método foi elaborado e fundamentado na instanciação de processos aos requisitos de negócio, desta maneira, a princípio o método pode ser aplicado para a instanciação de fábrica de software independente das características como tamanho e tipo de empresa das empresas na qual será utilizado. 


\section{APLICAÇÃO EXPERIMENTAL}

Neste capítulo serão abordados os princípios básicos da engenharia de software experimental, será discutido o que são e como podem ser utilizados em pesquisas onde existem empresas reais, com o objetivo de se definir um roteiro para os experimentos de aplicação do método de instanciação. Também serão apresentados dois experimentos utilizando-se o mesmo formato da engenharia de software experimental e os resultados serão analisados e comparados servindo assim de base para as conclusões e trabalhos futuros.

\subsection{MODELO DA APLICAÇÃO EXPERIMENTAL}

Este item irá apresentar o modelo metodológico utilizado na realização deste experimento.

Apesar de muitas disciplinas da Ciência e da Engenharia observarem o empirismo como um aspecto básico, esta mesma visão não tem sido uma tradição na engenharia de software. Um relacionamento simbiótico deve existir entre 0 desenvolvimento de teorias e os estudos empíricos que testam estas teorias, pois o estudo empírico auxilia no entendimento e na melhoria de produtos e processos de software. (BASILI, SELBY, HUTCHENS, 1986)

Existem três tipos de estratégia de pesquisa mais aceitas para aplicação experimental: (FREIMUT et al, 2002)

Pesquisas (Survey) - São investigações executadas em retrospectiva com objetivos descritivos (ex.: determinar uma distribuição dos atributos), exploratório (ex.: explicar o porque de dada situação) ou explorativo (ex.: estudo preliminar antes de uma investigação mais profunda). Investigação ampla onde a informação é coletada de maneira padronizada de um grupo definido de pessoas ou projetos.

Estudos de caso - possui um nível de controle baixo, pois se consegue observar os efeitos e muitas vezes não as causas. É uma investigação detalhada normalmente 
de um caso único ou um número de casos relacionados.

Experimentos - possui um nível de controle alto, com a definição das variáveis que serão experimentadas e das que serão mantidas fixas e dessa forma obter o resultado para realizar comparações com outros experimentos. Os experimentos são utilizados para se comprovar teorias, avaliar a predição de modelos ou validar medidas. Mas é método que demanda muito esforço na sua organização e execução já que é investigação detalhada e formal realizada em condições controladas.

É importante ressaltar que esta classificação das estratégias de pesquisa experimental não é a única. Mais tipos de classificação podem ser encontrados como mostrado em Freimut et al (2002).

Todas essas estratégias podem ter dois paradigmas de pesquisa, sendo uma pesquisa qualitativa ou uma pesquisa quantitativa. Vale ressaltar ainda que estes paradigmas podem estar presentes em uma mesma pesquisa.

Qualitativa é a pesquisa que busca explicar o fenômeno na maneira que as pessoas os fazem. São descrições que não oferecerem de maneira simples uma comparação, mas buscam explicar o porquê.

Quantitativa é a pesquisa que busca explicar o fenômeno de forma quantificada ou que possa ser comparado com a finalidade de identificar relações de causa e efeito.

Dentro deste conjunto de conceitos apresentados este trabalho apresentará um modelo de aplicação experimental do tipo experimento com o paradigma de pesquisa qualitativa, pois neste trabalho as variáveis do experimento que provém do ambiente real da empresa de software serão os requisitos de negócio e estas variáveis serão trabalhadas pelo pesquisador por meio de um método definido e controlado.

\subsection{OPERAÇÃO DA APLICAÇÃO EXPERIMENTAL}

A operação da aplicação experimental possui quatro etapas: Definição, 
Planejamento, Operação e Interpretação. A seguir serão explicados. Estas etapas serão apresentadas com informações reais da aplicação do método de instanciação de processos em empresas de software.

\subsubsection{Definição do experimento}

Esta é a primeira fase do processo experimental e consiste de seis partes que serão descritas a seguir:

- Motivação

A motivação para o pesquisador deste experimento é aumentar o entendimento sobre o fenômeno instanciação de processos através da aplicação prática em empresas reais. Essa aplicação prática foi definida seguindo-se os princípios de uma pesquisa do quadrante de Pasteur, onde o experimento prático e com foco na aplicação do conhecimento complementarão a teoria sobre a instanciação de processos.

- Objeto

O objeto do estudo é a primeira entidade examinada no experimento, no caso deste trabalho o objeto de estudo será o método de instanciação de processos em 2 empresas reais.

- Propósito

O propósito é caracterizar a instanciação através da aplicação do método em empresas reais. Essa caracterização envolverá discutir a aplicação de cada elemento do método durante seu uso em cada experimento e um comparativo entre os resultados.

- Perspectiva

A perspectiva representa a ótica do papel responsável pela execução da atividade 
de instanciação na fábrica de software. Desta maneira o experimento será executado sob a perspectiva de gerentes de projetos ou gerente de processos, ou até mesmo a equipe de desenvolvimento como um todo, pois, são os responsáveis diretos pela instanciação na fábrica de software. Os resultados coletados serão de grande utilidade para eles.

\section{- Domínio}

No caso desta dissertação o domínio do experimento será composto de empresas desenvolvedoras de software de qualquer tipo (ex.: aplicações desktop, web, móveis, ERPs, embarcado, tempo real, etc.) localizadas na Grande São Paulo, que estejam interessadas em organizar e definir seus processos aderentes ao conceito do modelo de fábrica de software integrada e de acordo com suas características de negócio específicas. Além disso, restringiu-se o experimento às pequenas empresas com no máximo 20 funcionários no departamento de desenvolvimento de software.

A justificativa para a escolha deste domínio foi o trabalho com pequenas empresas, que normalmente trabalham com poucos tipos de projetos, como até três projetos simultâneos. Essas restrições ao universo de empresas de software foi uma maneira encontrada para limitar a complexidade do experimento para tornar a execução mais rápida num curto espaço de tempo, pois empresas com mais de 20 funcionários têm uma chance maior de conter um grande número de projetos simultâneos o que demandaria ainda mais esforço do pesquisador para levantar os requisitos de negócio, diminuindo a viabilidade de realização de experimentos simultâneos.

As empresas contatadas estão interessadas na incorporação de qualidade ao desenvolvimento de software, desta maneira a obtenção do modelo de fábrica de software integrado aderente às características de negócio da empresa será interessante para empresa, e, para o pesquisador, porque apresenta uma forma de se aplicar o método de instanciação.

\section{- Escopo}

O escopo do experimento será a utilização do método de instanciação no domínio 
apresentado. O método é composto pela instanciação de tipo I e da instanciação de tipo II como apresentado no 3.2. Neste experimento somente será abordada a utilização do método de instanciação de tipo I. Todas as etapas do método de instanciação de tipo I serão realizadas e todos os subprodutos do método serão criados. O experimento se iniciará com a aceitação da empresa na colaboração da pesquisa e terminará com a aceitação da empresa a arquitetura de processos instanciada aderente aos requisitos de negócio da empresa.

\subsubsection{Planejamento do experimento}

O planejamento do experimento consiste em definir os detalhes das fases dos experimentos, como serão montados dentro do domínio, quais as variáveis que serão observadas, critérios de avaliação e qual a forma de medição (quantitativa ou qualitativa).

\subsubsection{Projeto}

De posse da definição, o planejamento do experimento consistiu das seguintes atividades:

- Definição da maneira para escolha das empresas para parceria no experimento

A definição da maneira para escolha das empresas para parceria no experimento consistiu em se elaborar uma forma de se escolher as empresas candidatas a realização do experimento. A maneira decidida para escolha da empresa foi o envio de convites para participação no experimento às empresas dos contatos profissionais do pesquisador e do orientador deste trabalho. As empresas que se interessassem pela participação seriam avaliadas quanto ao seu comprometimento ao experimento e possibilidade de início do projeto entre janeiro e junho de 2009 . O comprometimento foi medido através da aprovação da parceria para o experimento pela alta direção da empresa e também pela alocação de um responsável da empresa para intermediar as conversar entre pesquisador e a empresa. Caso estes 
três requisitos não fossem cumpridos a empresa era descartada.

- Definição das variáveis a serem observadas no experimento

As variáveis do experimento foram definidas com a finalidade de atender ao propósito do experimento que é caracterizar o fenômeno da instanciação. Considerando-se o método de instanciação do tipo I como um objeto processo, temse a Figura 28. Nessa figura o método de instanciação é representado pelo objeto processo, assim como apresentado na Figura 5 do item 2.3, os objetos processos possuem atributos e operações, no caso do objeto processo do método de instanciação os artefatos do método de instanciação são os atributos do objeto processo e as atividades (Especificação dos processos, Modelagem dos processos, Projeto dos processos) do método são as operações do objeto processo. Num objeto da computação os atributos são as variáveis que se modificam durante a execução do objeto.

\begin{tabular}{|c|c|}
\hline Objeto processo & \\
\hline sartefato & $\rightarrow$ Método de instanciação \\
\hline $\begin{array}{l}\text { recurso } \\
\text { spolítica }\end{array}$ & -Artefato \{\} \\
\hline da at & +Atividades() \\
\hline
\end{tabular}

Figura 28 - objeto processo do método de instanciação.

Desta maneira, no objeto processo que representa o método de instanciação, as variáveis são os artefatos do método, por isso, os artefatos serão as variáveis do experimento, ao observar estes artefatos e entender seu relacionamento na prática poderá se caracterizar o fenômeno da instanciação.

As variáveis são apresentadas na Tabela 6 a seguir, a descrição dessas variáveis podem ser encontradas no item 3.3.1 deste trabalho: 


\begin{tabular}{|l|}
\hline Variáveis \\
\hline Tabela de categorização de requisitos de negócio da fábrica por visões \\
\hline Matriz de requisitos de negócio e impacto nos objetos processos \\
\hline Diagrama descritivo da atividade \\
\hline Diagrama descritivo dos papéis \\
\hline Diagrama descritivo do artefato \\
\hline Diagrama estrutural do processo e da atividade \\
\hline Diagrama de estados do processo \\
\hline Diagrama dos estados das atividades do processo \\
\hline Diagrama dos estados dos atores do processo \\
\hline Diagrama dos estados dos artefatos do processo \\
\hline Diagrama de fluxo de seqüência e de mensagens entre atividades \\
\hline Templates dos artefatos \\
\hline Guia de processos \\
\hline
\end{tabular}

Tabela 6 - Variáveis do experimento

\subsubsection{Critérios de avaliação}

Para cada uma das variáveis analisadas será apresentado o critério de avaliação. 0 critério significa o que irá se avaliar da variável. Além disso, as variáveis propostas são capturadas a partir da avaliação dos produtos do método de instanciação.

A seguir, Tabela 7 , apresenta as variáveis e como será o critério de avaliação de cada uma delas 


\begin{tabular}{|c|c|}
\hline Variáveis do experimento & Critério de avaliação \\
\hline $\begin{array}{l}\text { Tabela de categorização de requisitos de } \\
\text { negócio da fábrica por visões }\end{array}$ & $\begin{array}{l}\text { Verificar se todos os requisitos } \\
\text { puderam ser categorizados. }\end{array}$ \\
\hline $\begin{array}{l}\text { Matriz de requisitos de negócio e impacto } \\
\text { nos objetos processos }\end{array}$ & $\begin{array}{l}\text { Verificar se todas as relações de } \\
\text { requisitos com processos da } \\
\text { arquitetura de referência puderam ser } \\
\text { analisadas e os tipos de ações a } \\
\text { serem realizadas (adicionar, remover, } \\
\text { etc) }\end{array}$ \\
\hline Diagrama descritivo da atividade & $\begin{array}{l}\text { Verificar as principais alterações } \\
\text { realizadas em relação à arquitetura } \\
\text { de referência (a definição da } \\
\text { arquitetura de referência pode ser } \\
\text { encontrada no item 2.4) }\end{array}$ \\
\hline Diagrama descritivo dos papéis & $\begin{array}{l}\text { Verificar as principais alterações } \\
\text { realizadas em relação à arquitetura } \\
\text { de referência }\end{array}$ \\
\hline Diagrama descritivo do artefato & $\begin{array}{l}\text { Verificar as principais alterações } \\
\text { realizadas em relação à arquitetura } \\
\text { de referência }\end{array}$ \\
\hline $\begin{array}{l}\text { Diagrama estrutural do processo e da } \\
\text { atividade }\end{array}$ & $\begin{array}{l}\text { Verificar as principais alterações } \\
\text { realizadas em relação à arquitetura } \\
\text { de referência }\end{array}$ \\
\hline Diagrama de estados do processo & $\begin{array}{l}\text { Verificar as principais alterações } \\
\text { realizadas em relação à arquitetura } \\
\text { de referência }\end{array}$ \\
\hline $\begin{array}{l}\text { Diagrama dos estados das atividades do } \\
\text { processo }\end{array}$ & $\begin{array}{l}\text { Verificar as principais alterações } \\
\text { realizadas em relação à arquitetura } \\
\text { de referência }\end{array}$ \\
\hline $\begin{array}{l}\text { Diagrama dos estados dos atores do } \\
\text { processo }\end{array}$ & $\begin{array}{l}\text { Verificar as principais alterações } \\
\text { realizadas em relação à arquitetura } \\
\text { de referência }\end{array}$ \\
\hline
\end{tabular}




\begin{tabular}{|l|l|}
\hline $\begin{array}{l}\text { Diagrama dos estados dos artefatos do } \\
\text { processo }\end{array}$ & $\begin{array}{l}\text { Verificar as principais alterações } \\
\text { realizadas em relação à arquitetura } \\
\text { de referência }\end{array}$ \\
\hline $\begin{array}{l}\text { Diagrama de fluxo de seqüência e de } \\
\text { mensagens entre atividades }\end{array}$ & $\begin{array}{l}\text { Verificar as principais alterações } \\
\text { realizadas em relação à arquitetura } \\
\text { de referência }\end{array}$ \\
\hline Templates dos artefatos & $\begin{array}{l}\text { Verificar as principais alterações } \\
\text { realizadas em relação à arquitetura } \\
\text { de referência }\end{array}$ \\
\hline Guia de processos & $\begin{array}{l}\text { Comparar a arquitetura de referência } \\
\text { e a arquitetura operacional gerada. }\end{array}$ \\
\hline
\end{tabular}

Tabela 7 - Critérios das variáveis

\subsubsection{Medidas}

As medições serão análises qualitativas baseadas nos critérios de cada variável do experimento.

\subsubsection{Operação do experimento}

Nesta etapa da aplicação experimental são preparados os experimentos, em seguidas são executados com as empresas e por fim são analisados os dados coletados.

\subsubsection{Preparação}

Os experimentos seguiram a seguinte preparação:

- Seleção das empresas candidatas

- Apresentação do experimento e do modelo da parceria na pesquisa

- Realização de acordo entre pesquisador e empresa

- Cronograma inicial do trabalho e divisão das responsabilidades

A seleção das empresas foi feita a partir dos contados do pesquisador e do 
orientador com profissionais em empresas de software com cargos de responsabilidade sobre o desenvolvimento de software. Para estes profissionais foi enviada uma apresentação sobre o experimento, a parceria e como eles deveriam proceder no caso de se interessarem pelo projeto.

Para as empresas que se interessaram pelo projeto uma reunião foi marcada para apresentação detalhada do formato do experimento, das responsabilidades de cada equipe, do esforço envolvido, uma estimativa de duração do projeto e a maneira como seriam manipulados os dados. Nesta etapa sete empresas estavam interessadas.

Se houvesse o interesse pela execução do experimento em parceria com a empresa o termo de responsabilidade, como apresentado na Figura 29, era assinado para então se iniciar os trabalhos.

Das sete empresas apenas quatro iniciaram o processo. Uma das empresas tinha interesse, mas o início deveria ocorrer após junho de 2009 por conta da dinâmica da empresa. A outra empresa excluída do experimento possuía mais de 20 profissionais na equipe de desenvolvimento de software. E a terceira respondeu o email com interesse, porém não se apresentou para as fases seguintes. 
[ste Termo de Cunfidencialidade visa estabelecer um acordo entrc os pescluisacores Leonardo Uominguez Dias, Jorge Luls Risco Becerra c: Gabricla Cabel Barbarán, doravante denuminudos Pesquisadores. E t i empresi

- doravante denominada Empresa Participantc, a respeito da rontidencialidade das informaç̄es coletadas duranle o proces5o de pasquisa intitulado: "Méludo de Instarciarân de Fàbricas de Suliw ure", sob orientaçäo do prot. Jorge Luis K sco bccerro.

Através deste Termo de Confidencialidade, os Pesquisadores se compromeiern d:

- Najo divulgar o nome da Empresa Participante, em qualquer meio, a menos que expressamante autorizado por esli.

Divulgar ou rucer uso das infornaçes coletadas comi lins acedèmicos e de profuisa em formato de traps, artigos a apresenliḑüs, dos quais nän se possa retirar ou infenir a identiticaçï: da Empresa Participante

Nä̀ utilizar as informaçōes calctudas para lins comẹr.iais como a realizaçăo de senjiços que pussan ser consideradns idénticos ou que possarn ser considerados conrorrentes aos realizados pela Empresa Participante.

As assinaturas ahaixo expressan a concordància quarto ao cumprimente desle lerno ce Conticencialidade; por prazo indeterminado.

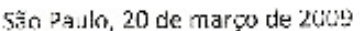

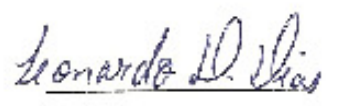

Leonardo Dumingez [ias
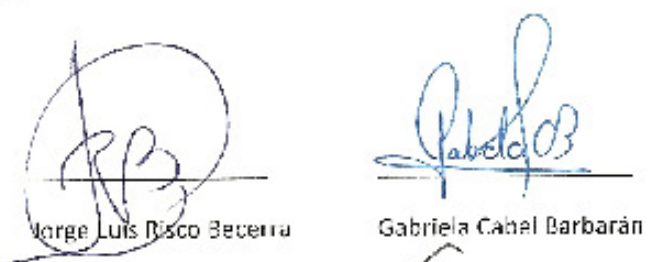

Gabriela Canel Barbaràn

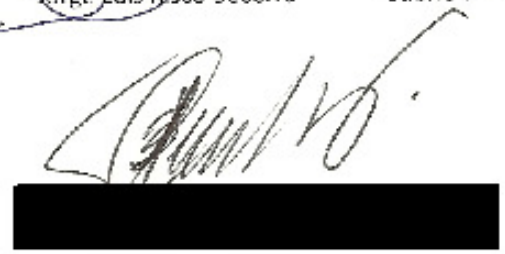

Figura 29 - exemplo do termo de confidencialidade assinado entre os pesquisadores e empresa participante do experimento.

Das quatro empresas interessadas foi realizado com cada uma delas a reunião inicial e após a reunião apenas duas assinaram o termo de confidencialidade. Das duas empresas que não assinaram, a primeira ao compreender o esforço envolvido 
por parte dela, disse não dispor de tempo para execução dos trabalhos. A segunda iniciou o processo juntamente com uma consultoria externa em MPS.BR, mas o líder da equipe desistiu do projeto logo no início devido a outras prioridades da empresa.

Desta maneira somente duas das empresas iniciaram o projeto. Após a assinatura do termo de confidencialidade então era elaborado um cronograma com as etapas do método de instanciação. Segue o modelo do cronograma elaborado. No cronograma a expectativa era que o experimento ocorresse em 117 dias úteis. Aproximadamente 5 meses.

Além das etapas do método instanciação (Especificação, Modelagem e Projeto) foram incluídas outras duas etapas Implantação Piloto e Institucionalização. A implantação piloto é a etapa em que a arquitetura de processo será utiliza pela equipe num projeto, a intenção dessa etapa era para que o pesquisador assistisse a equipe na utilização do processo. A institucionalização era a formalização da arquitetura de processos em todos os projetos da empresa para o acompanhamento de demais projetos pelo pesquisador com a finalidade de colher dados sobre o uso dos processos na empresa. 


\begin{tabular}{|c|c|c|c|}
\hline Tarefas & Duração & Início & Fim \\
\hline Experimento com empresa & 117 dias & $16 / 3 / 09$ & $25 / 8 / 09$ \\
\hline Especificação dos processos & 30 dias & $16 / 3 / 09$ & $24 / 4 / 09$ \\
\hline Levantamento dos requisitos de negócio & 3 dias & $16 / 3 / 09$ & $18 / 3 / 09$ \\
\hline Levantamento detalhado processos e sistemas & 12 dias & $16 / 3 / 09$ & $31 / 3 / 09$ \\
\hline $\begin{array}{l}\text { Especificação dos processos existentes (se } \\
\text { houver) }\end{array}$ & 10 dias & $1 / 4 / 09$ & $14 / 4 / 09$ \\
\hline Validação dos processos & 30 dias & $16 / 3 / 09$ & $20 / 4 / 09$ \\
\hline Modelagem & 24 dias & $27 / 4 / 09$ & $28 / 5 / 09$ \\
\hline Análise dos processos - & 12 dias & $27 / 4 / 09$ & $12 / 5 / 09$ \\
\hline Análise dos processos - modelo comportamental & 12 dias & $13 / 5 / 09$ & $28 / 5 / 09$ \\
\hline Projeto de Processos & 22 dias & $29 / 5 / 09$ & $29 / 6 / 09$ \\
\hline Criação dos artefatos template & 12 dias & $29 / 5 / 09$ & $15 / 6 / 09$ \\
\hline Elaboração do guia de processos corporativo & 10 dias & $16 / 6 / 09$ & $29 / 6 / 09$ \\
\hline Implantação Piloto & 21 dias & $30 / 6 / 09$ & $28 / 7 / 09$ \\
\hline Definição da estratégia de implantação & 5 dias & $30 / 6 / 09$ & $6 / 7 / 09$ \\
\hline Aplicação dos processos em projetos & 15 dias & $7 / 7 / 09$ & $27 / 7 / 09$ \\
\hline Workshop de ajuste de falhas & 1 dia & $28 / 7 / 09$ & $28 / 7 / 09$ \\
\hline Institucionalização dos processos & 20 dias & $29 / 7 / 09$ & $25 / 8 / 09$ \\
\hline Acompanhamento dos projetos & 15 dias & $29 / 7 / 09$ & $18 / 8 / 09$ \\
\hline Relatório de conclusão de atividades & 5 dias & $19 / 8 / 09$ & $25 / 8 / 09$ \\
\hline
\end{tabular}

Tabela 8 - Cronograma inicial das atividades na empresa $A$

\subsubsection{Execução na Empresa $A$}

Neste item será dada uma breve descrição sobre a empresa A e os resultados sobre o experimento.

- Descrição da empresa A

Devido ao termo de confidencialidade assinado entre os pesquisadores e a empresa essa será chamada de empresa $A$.

A empresa A é uma empresa que desenvolveu um ERP próprio e comercializa para associações e clubes esportivos, esse ERP foi desenvolvido na tecnologia .NET da 
Microsoft, além disso, a empresa realiza o desenvolvimento de customizações de em um ERP de uma grande empresa de software em uma linguagem proprietária.

No início dos trabalhos a empresa contava com 23 funcionários. Sendo 9 da área de desenvolvimento de software e quatro consultores especialistas no ERP proprietário quer eram contratados quando projetos eram vendidos pela empresa.

Segue o organograma da empresa na Figura 30. Os cargos que estão destacados em cinza são cargos relacionados com o processo de desenvolvimento de software.

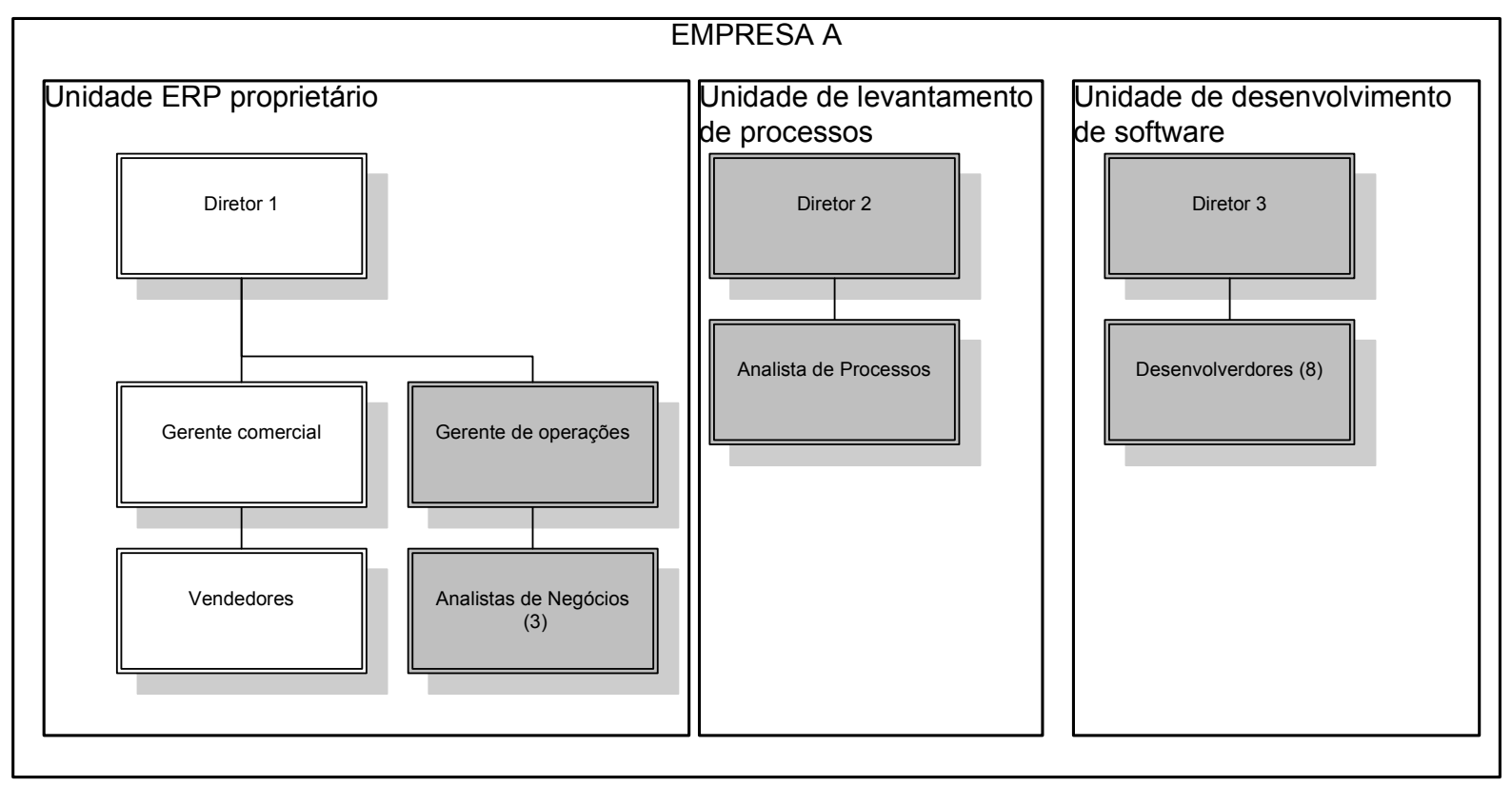

Figura 30 - Organograma da empresa A

Segundo o levantamento realizado com os diretores para aprovação do projeto, a decisão pela aceitação do experimento com a empresa ocorreu por que a empresa vem crescendo e existe uma necessidade de formalização das atividades executadas para aumentar o controle e qualidade do que é feito pela empresa.

O levantamento é feito de maneiras diferentes em cada cliente e a especificação do projeto não é padronizada, o que causou falhas no desenvolvimento de projetos passadas, gerando retrabalhos e conflitos com os clientes.

- Aplicação experimental do método de instanciação

O experimento iniciou com a apresentação dos pesquisadores e da proposta de 
parceria para toda a equipe da empresa, apresentado o que seria feito, porque e como cada um deles iria participar do processo.

Após essa apresentação foram realizadas entrevistas com todas as pessoas a partir do questionário. As respostas aos questionários estão no APÊNDICE A Questionário e Respostas ao questionário - Empresa A. Além de responderem as perguntas do questionário foi solicitado aos entrevistados que fornecessem cópias dos documentos utilizados na empresa e no caso das tarefas serem feitas com o auxílio de sistemas foram solicitadas imagens das telas do sistema. Desta maneira, foi possível se levantar todos os artefatos existentes atualmente na empresa.

Como a empresa $A$ já desenvolvia software ela já possuía alguns processos. Então após a coleta do questionário foi necessário mapear esses processos de acordo com a arquitetura de referência, para isso foi utilizada uma tabela onde estão todos os processos e atividades da arquitetura de referência e um mapeamento é realizado para se verificar quais processos da arquitetura de referência a empresa possui, quais ela possui parcialmente (dependendo do projeto pode executar) e quais não possui. Essa identificação é importante, pois, os processos ou elementos de processo que a empresa já possua devem ser mantidos, pois isso é uma maneira de garantir a aderência da fábrica de software ao negócio.

A Tabela 9 apresenta o resultado para o processo de gestão de acordos com fornecedores como um exemplo do cruzamento de processos da arquitetura de referência com os processos já existentes na empresa $A$. Nelas todas as atividades do processo de gestão de acordos com fornecedores estão na coluna da esquerda e caso essa atividade já fosse realizada pela empresa $A$ se coloca um $X$ na coluna existe, caso fosse realizada parcialmente coloca-se um $X$ na coluna Parcial e caso não se encontre evidencias que seja executado coloca-se um $X$ na coluna sem evidências. 


\begin{tabular}{|c|c|c|c|c|}
\hline Atividades & Existe & Parcial & $\begin{array}{l}\text { Sem } \\
\text { Evidências }\end{array}$ & Comentários \\
\hline Determinar o tipo de aquisição & & $\mathrm{x}$ & & $\begin{array}{l}\text { Segundo os documentos os fornecedores, } \\
\text { chamados de parceiros pela empresa A, } \\
\text { participam somente das atividades de } \\
\text { implementação e implantação. }\end{array}$ \\
\hline Selecionar fornecedores & $x$ & & & $\begin{array}{l}\text { Existe a escolha do fornecedor a partir das } \\
\text { habilidade e experiência em projetos } \\
\text { anteriores }\end{array}$ \\
\hline Estabelecer acordos/contratos & & $\mathrm{x}$ & & $\begin{array}{l}\text { Existem contratos estabelecidos com } \\
\text { parceiros no desenvolvimento de projetos. }\end{array}$ \\
\hline Execução de acordos & & $x$ & & $\begin{array}{l}\text { Problemas com acordos acontecem por } \\
\text { falhas tanto da empresa A quando por parte } \\
\text { do fornecedor devido a não executarem o } \\
\text { acordo no prazo acordado. }\end{array}$ \\
\hline $\begin{array}{l}\text { Monitorar o processo de } \\
\text { fornecedores selecionados }\end{array}$ & & & $x$ & \\
\hline $\begin{array}{l}\text { Avaliar os produtos de } \\
\text { fornecedores selecionador }\end{array}$ & & $x$ & & $\begin{array}{l}\text { É realizada a aceitação de forma verbal, mas } \\
\text { não ficam registros sobre a execução. }\end{array}$ \\
\hline $\begin{array}{l}\text { Realizar a aceitação dos } \\
\text { produtos dos forncedores }\end{array}$ & & & $x$ & \\
\hline Produtos de transição & & & $x$ & \\
\hline
\end{tabular}

Tabela 9 - Exemplo do cruzamento dos processos da arquitetura de referência aos processos já existentes na empresa $A$.

Com base nas respostas os requisitos de negócio foram descritos, classificados e categorizados. Segue um resumo da tabela dos requisitos de negócio da empresa $A$ Tabela 10. A tabela toda pode ser encontrada no apêndice B. 


\begin{tabular}{|l|l|}
\hline ID & Descrição dos requisitos de negócio \\
\hline 1 & $\begin{array}{l}\text { A empresa desenvolve projetos de } 4 \text { tipos (desenvolvimento de } \\
\text { customizações e implantação de ERP de uma grande empresa, } \\
\text { desenvolvimento de portais web, desenvolvimento de aplicativos } \\
\text { móveis e manutenção e customização do produto ERP para } \\
\text { associações e clubes esportivos desenvolvido internamente) }\end{array}$ \\
\hline 2 & $\begin{array}{l}\text { Tornar-se referência em desenvolvimento para uma grande empresa. } \\
\text { Desenvolvimento com qualidade, sem retrabalhos e dentro do prazo } \\
\text { acordado com cliente. }\end{array}$ \\
\hline 3 & $\begin{array}{l}\text { Aumentar o conhecimento da equipe de desenvolvimento Web/Mobile. } \\
\text { Através de projetos mais organizados, consulta a projetos já } \\
\text { realizados. }\end{array}$ \\
\hline 4 & $\begin{array}{l}\text { A empresa contrata consultores especificamente para cada projeto de } \\
\text { desenvolvimento de customizações e implantação do ERP do } \\
\text { fornecedor de uma grande empresa. }\end{array}$ \\
\hline 5 & $\begin{array}{l}\text { Aumentar o formalismo no controle de projeto principalmente nas } \\
\text { entregas, com indicadores por cada etapa do desenvolvimento }\end{array}$ \\
\hline 6 & $\begin{array}{l}\text { Manter uma base dos códigos implantados nos clientes } \\
\text { Controle dos pagamentos ao consultor que realiza projetos nos clientes } \\
\text { através do preenchimento da Ordem de Serviço. }\end{array}$ \\
\hline Tabe
\end{tabular}

Tabela 10 - Resumo da tabela de identificação dos Requisitos de negócio da empresa A.

Esses requisitos foram classificados nas seguintes categorias, Tabela 11, como foi explicado no capítulo 3: 


\begin{tabular}{|l|l|l|}
\hline Visões & Categorias & Candidatos a Requisitos \\
\hline \multirow{5}{*}{ Empresa } & Políticas & \\
\hline & Procedimentos & 7,12 \\
\cline { 2 - 3 } & Unidades organizacionais & \\
\hline \multirow{5}{*}{ Earacterísticas da Empresa } & $2,3,5$ \\
\hline & Papéis corporativos & 8 \\
\hline & Agencias regulamentadoras & \\
\hline & Stakeholders & \\
\hline & Fornecedores & 4 \\
\hline & Mercado de & 9 \\
\hline \multirow{5}{*}{ Engenharia } & $\begin{array}{l}\text { Tipos } \\
\text { Informação }\end{array}$ & 1 \\
\hline Tecnologia & Recursos utilizados & 6 \\
\hline & Processos & 14 \\
\hline Computação & Padrões & $10,11,13$ \\
\hline & Produtos de software & \\
\hline & Tecnologias utilizadas & \\
\hline & Ferramentas & \\
\hline
\end{tabular}

Tabela 11 - Tabela de categorização de requisitos de negócio da fábrica por visões, empresa A.

A partir desses requisitos foi criada a matriz de impactos dos requisitos na arquitetura de processos de referência. A Tabela 12 a seguir apresenta um resumo da matriz de impacto da empresa A. 


\begin{tabular}{|c|c|c|c|}
\hline $\begin{array}{l}\text { Id do Requisito } \\
\text { de negócio }\end{array}$ & $\begin{array}{l}\text { Processos da } \\
\text { Arquitetura de } \\
\text { referência } \\
\text { impactados }\end{array}$ & $\begin{array}{c}\text { Elementos do } \\
\text { processo impactados }\end{array}$ & $\begin{array}{l}\text { Ação a ser } \\
\text { executada }\end{array}$ \\
\hline 1 & Desenvolvimento & $\begin{array}{l}\text { Todas as atividades e } \\
\text { artefatos. }\end{array}$ & Redefinir \\
\hline \multirow[t]{2}{*}{2} & Planejamento & $\begin{array}{l}\text { Atividade: Determinação } \\
\text { de estimativas de } \\
\text { esforço }\end{array}$ & Redefinir \\
\hline & Medidas e Análises & $\begin{array}{l}\text { Artefato: Métrica de } \\
\text { qualidade, esforço }\end{array}$ & Adicionar \\
\hline \multirow[t]{2}{*}{3} & Desenvolvimento, & Artefatos do processo & Expandir \\
\hline & $\begin{array}{l}\text { Gerência } \\
\text { configuração }\end{array}$ & $\begin{array}{l}\text { Artefato: Histórico de } \\
\text { projeto }\end{array}$ & Adicionar \\
\hline \multirow[t]{2}{*}{4} & \multirow{2}{*}{$\begin{array}{l}\text { Processo de acordo } \\
\text { com fornecedor }\end{array}$} & Artefato & Redefinir \\
\hline & & Atividade & Redefinir \\
\hline \multirow[t]{3}{*}{5} & & Atividade: Implantação & Expandir \\
\hline & Desenvolvimento & $\begin{array}{l}\text { Artefato: Plano de } \\
\text { Implantação com testes } \\
\text { de aceitação }\end{array}$ & Expandir \\
\hline & $\begin{array}{l}\text { Gerência } \\
\text { configuraç!ao }\end{array}$ & $\begin{array}{l}\text { Artefato: Plano de } \\
\text { Implantação com testes } \\
\text { de aceitação }\end{array}$ & Expandir \\
\hline 6 & $\begin{array}{l}\text { Gerência } \\
\text { configuração }\end{array}$ & $\begin{array}{l}\text { Atividade: Armazenar } \\
\text { código implantado no } \\
\text { cliente e configurações }\end{array}$ & Expandir \\
\hline 7 & $\begin{array}{l}\text { Acordo } \\
\text { fornecedor }\end{array}$ & Artefato: Ordem dea & $\begin{array}{l}\text { Substituir } \\
\text { relatório de } \\
\text { acompanhamento } \\
\text { de atividades }\end{array}$ \\
\hline 8 & Nenhum & & \\
\hline 9 & Nenhum & & \\
\hline
\end{tabular}




\begin{tabular}{|c|c|c|c|}
\hline \multirow[t]{3}{*}{10} & $\begin{array}{l}\text { Monitoramento do } \\
\text { projeto }\end{array}$ & Artefato: Revisão & Expandir \\
\hline & $\begin{array}{ll}\text { Gerência } & \text { da } \\
\text { Qualidade } & \end{array}$ & $\begin{array}{l}\text { Atividade: Revisão dos } \\
\text { artefatos e processo }\end{array}$ & Redefinir \\
\hline & Medidas e análises & Atividade: & Expandir \\
\hline \multirow[t]{2}{*}{11} & Planejamento & Atividade: & Expandir \\
\hline & $\begin{array}{l}\text { Monitoramento do } \\
\text { projeto }\end{array}$ & $\begin{array}{l}\text { Atividade: } \\
\text { Monitoramento }\end{array}$ & Expandir \\
\hline \multirow[t]{3}{*}{12} & & Atividades: Todas & Redefinir \\
\hline & Desenvolvimento & Artefatos: Todos & Redefinir \\
\hline & Planejamento & Atividades: Todas & Redefinir \\
\hline 13 & Nenhum & & \\
\hline \multirow[t]{3}{*}{14} & Desenvolvimento & Artefatos: Especificação & Redefinir \\
\hline & $\begin{array}{l}\text { Planejamento } \\
\text { projeto. }\end{array}$ & $\begin{array}{l}\text { Atividade: estimativa de } \\
\text { esforço e custo }\end{array}$ & Redefinir \\
\hline & $\begin{array}{l}\text { Monitoramento } \\
\text { controle dos projetos }\end{array}$ & Artefatos: Cronograma & Substituir \\
\hline 15 & $\begin{array}{l}\text { Utilizar arquitetura de } \\
\text { referência CMMI }\end{array}$ & & \\
\hline
\end{tabular}

Tabela 12 - Resumo da matriz de impacto da empresa $A$

A partir da Tabela 12 foi gerada a especificação detalhada, contendo os processos que seriam idênticos aos da arquitetura de referência e as adequações, esta foi validada em reunião com a equipe de desenvolvimento da empresa $A$. APÊNDICE $B$ - ESPECIFICAÇÃO DOS PROCESSOS DA EMPRESA A. A Tabela 13 apresenta a especificação de um dos processos da arquitetura operacional da fábrica de software da empresa $A$. 


\begin{tabular}{|c|c|}
\hline Nome: & PGQ 1. Verificação do uso de todos os processos \\
\hline Tipo: & Atividade Operacional \\
\hline Descrição: & $\begin{array}{l}\text { Esta atividade faz a verifica se todos os processos foram } \\
\text { utilizados no projeto, pois garantir a execução dos processos } \\
\text { é garantir a qualidade. }\end{array}$ \\
\hline Meta: & Todas as atividades executadas verificadas \\
\hline Pré-condições: & Processos da Fábrica implantados. \\
\hline Artefato (entrada): & \begin{tabular}{|l|} 
Guia de processos. \\
Cronograma atualizado
\end{tabular} \\
\hline Ações: & $\begin{array}{l}\text { 1) Verificar no cronograma: } \\
\text { a. As atividades executadas. } \\
\text { b. A seqüência de execução das atividades. } \\
\text { c. Os papéis que executaram as atividades. } \\
\text { d. O tempo de execução da atividade. } \\
\text { 2) Usando o guia de processos verificar se as atividades } \\
\text { identificaadas, a seqüência, os papéis e os tempos de } \\
\text { execução atendem aos processos estabelecidos no guia. } \\
\text { 3) Se for identificado que as atividades e a forma como } \\
\text { elas estão sendo realizadas não atendem às estabelecidas } \\
\text { nos processos definidos, identificar a causa. } \\
\text { a. Se for, em função de mudanças nos processos, } \\
\text { atualizar o guia de processos. } \\
\text { b. Se for, pela falta de conhecimento dos funcionários da } \\
\text { empresa, realizar um treinamento usando o guia de } \\
\text { processos. } \\
\text { c. Se for, pela falta de conhecimento técnico na execução } \\
\text { da atividade, treinar o funcionário ou alocar um funcionário } \\
\text { com o conhecimento necessário. } \\
\text { 4) Preenche o Timesheet e armazena no repositório. }\end{array}$ \\
\hline Recursos: & Ferramenta para elaborar a documentação \\
\hline Habilidades: & Conhecimento dos processos da empresa. \\
\hline Artefato (saída): & Relatório da gestão da qualidade. \\
\hline Controle: & $\begin{array}{l}\text { Esta atividade deverá ser executada por uma pessoa externa } \\
\text { ao projeto. }\end{array}$ \\
\hline Métricas: & $\begin{array}{l}\text { Verificar o uso dos processos definidos da empresa. } \\
\text { Número de atividades realizadas } \\
\text { Número de atividades novas } \\
\text { Tempo de execução das atividades } \\
\text { Número de atividades realizadas por outros papéis (não } \\
\text { responsável pela execução da atividade). }\end{array}$ \\
\hline
\end{tabular}

Tabela 13 - Diagrama descritivo da atividade. Exemplo de diagrama estrutural da empresa $A$. 


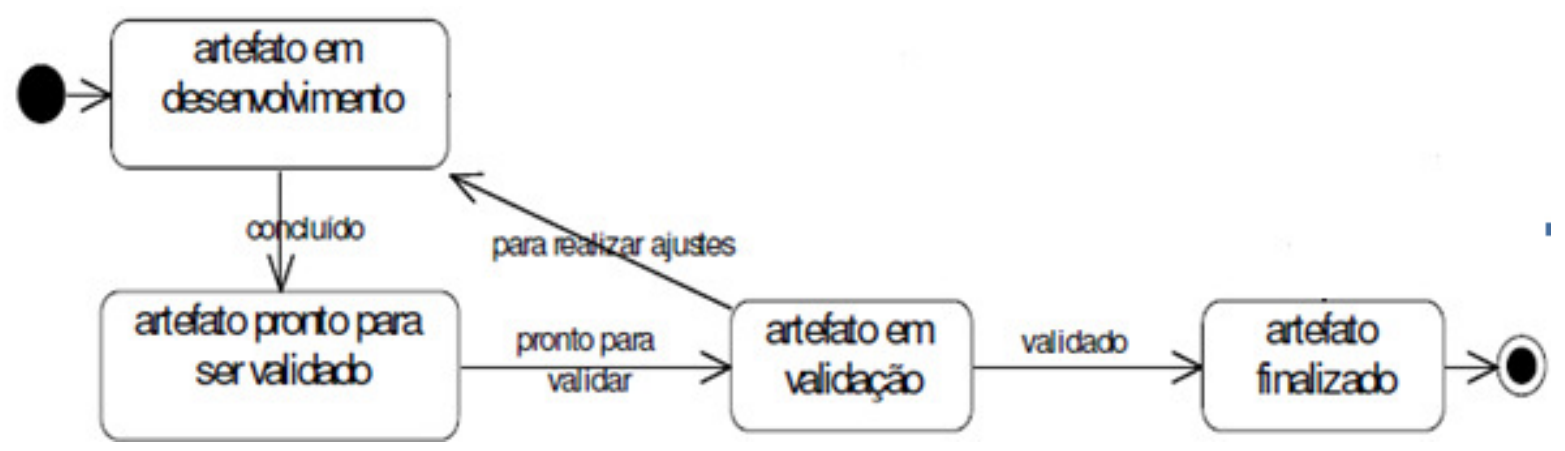

Figura 31 - Diagrama de estados do artefato da empresa A.

\begin{tabular}{|c|c|}
\hline $\begin{array}{l}\text { Processo de Gestão de } \\
\text { acordos com fornecedores }\end{array}$ & Atividade Selecionar Fornecedor \\
\hline \multirow[t]{2}{*}{$\begin{array}{l}\text { - Objetivo: Gerenciar os } \\
\text { contratos com forncedores } \\
\text { - Tipo: Gerencial } \\
\text { - Estado: ativo }\end{array}$} & $\begin{array}{l}\text { - Tipo: operacional } \\
\text { - Descrição: Seleção da forma de } \\
\text { fornecimento e do tipo de fornecedor } \\
\text { de um produto ou serviço para o } \\
\text { projeto. } \\
\text { - Meta: Cronograma do projeto } \\
\text { que define } \\
\text {-Pré: Contrato do projeto permite } \\
\text { sub-contratações } \\
\text { - Pós: Contratos assinado } \\
\text { Estado: ativa }\end{array}$ \\
\hline & $\begin{array}{l}\text { - Determinar o tipo de aquisição. } \\
\text { Produto pronto, compra de } \\
\text { desenvolvimento, produto semi- } \\
\text { pronto mais treinamento no produto } \\
\text { para equipe customizar() } \\
\text { - Selecionar os possíveis } \\
\text { fornecedores, avaliando através } \\
\text { planilha de perfil de fornecedores a } \\
\text { competência técnica, preço, prazo, } \\
\text { garantias, eficiência em projetos } \\
\text { anteriores e suporte fornecidos() } \\
\text { - Análise e escolha da proposta() } \\
\text { - Assinatura do contrato() }\end{array}$ \\
\hline
\end{tabular}

Figura 32 - Exemplo de diagrama estrutural do processo e da atividade da empresa A, para o processo de Gestão de acordos com fornecedores.

Na Figura 31 é apresentado o digrama de estados dos artefatos da empresa A. Todos os artefatos seguem esse modelo de estados. Uma adequação neste modelo em relação a arquitetura de referência foi necessária. O estado "artefato em integração" que existia no diagrama de estados do artefato da arquitetura de referência foi removido, pois para os artefatos da fábrica de software da empresa $A$ 
esse estado não se aplicava.

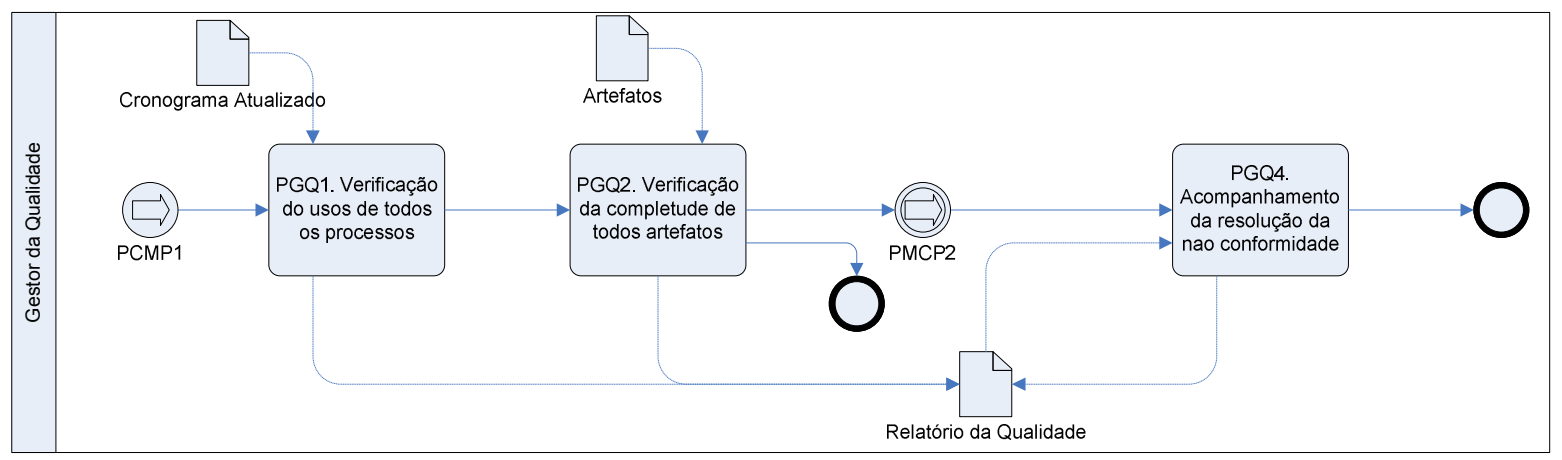

Figura 33 - Diagrama de fluxo de seqüência e de mensagens. Exemplo de diagrama comportamental da Empresa A.

Após a especificação iniciou-se a etapa de modelagem dos processos. Os modelos da empresa A podem ser observados no APÊNDICE C - MODELOS DOS PROCESSOS DA EMPRESA A. Os modelos também foram validados pela equipe de desenvolvimento (cliente).

A Figura 34 - Imagem do guia de processos apresenta uma imagem do guia de processos. No guia ficam visíveis as mensagens enviadas entre a fábrica e entidades externas como clientes. Também é possível verificar as ligações entre este processo apresentado e outros processos, estas ligações (links) são representadas pelos círculos com borda dupla e uma seta dentro. O guia também tem funcionalidades interativas, pois permite que ao clicar num documento o conteúdo deste documento seja exibido e também ao clicar numa ligação que o processo que esta sendo referenciado nesta ligação seja aberto, facilitando assim a navegação entre processos e o entendimento dos processos. 


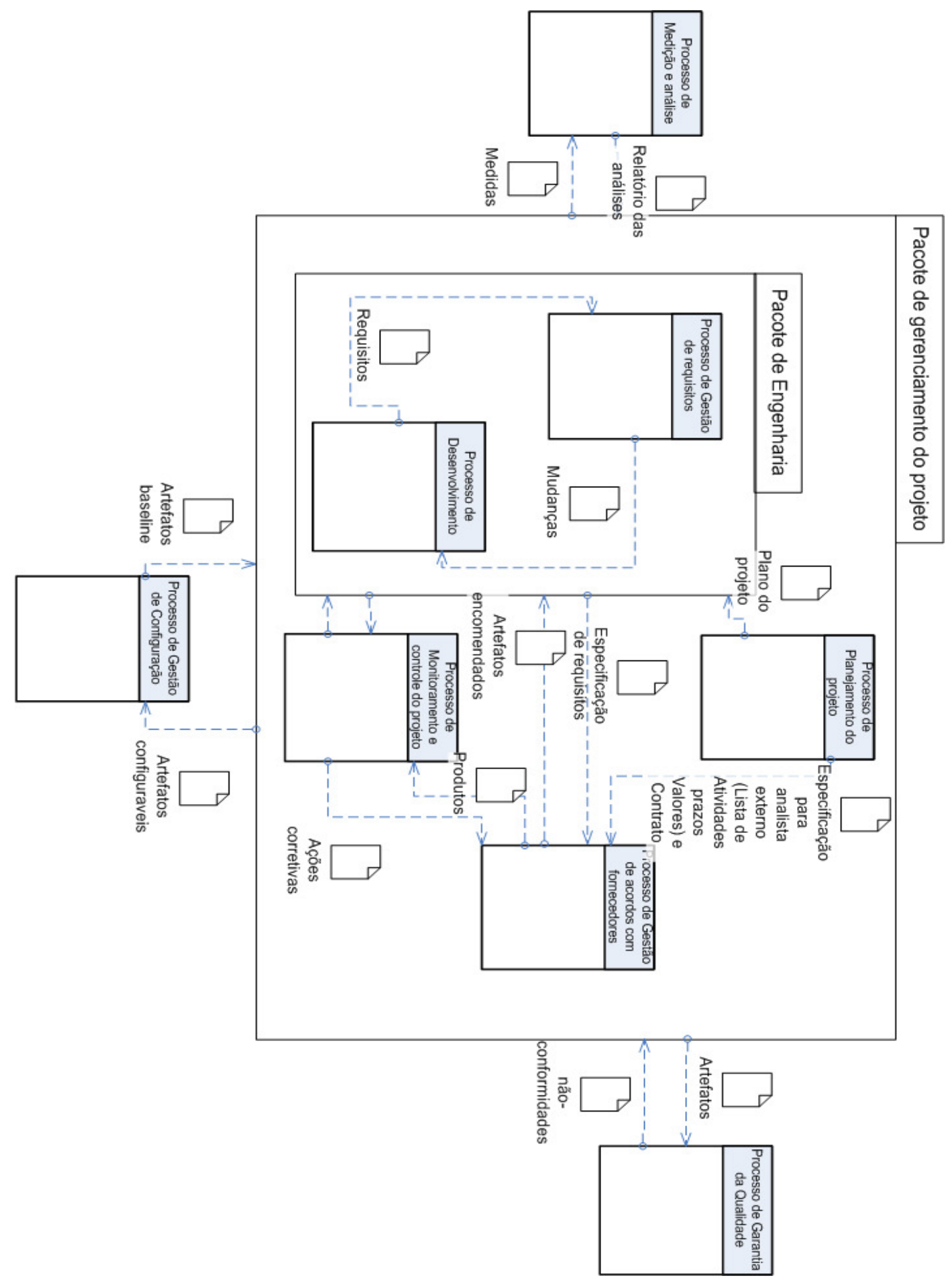

Figura 34 - Imagem do guia de processos da empresa A

4.2.3.3 Análise dos resultados da aplicação experimental na empresa A

Como resultado da aplicação do método na empresa $A$ foi possível observar que todos os sub-produtos do método de instanciação foram gerados como esperado. Desta maneira, para a situação da empresa A o método foi utilizado como sucesso. 
A etapa de especificação dos processos foi uma etapa que exigiu bastante análise e conhecimento da empresa. O conhecimento foi necessário para entendimento dos requisitos de negócio da empresa $A$, pois durante a aplicação dos questionários 0 entrevistador precisa dinamicamente entender como são chamados os artefatos, atividades, papéis a empresa entender qual o objetivo de cada um deles, por exemplo, para a empresa A a especificação de software é chamada de documento de descrição de funcionalidade, mas não continha itens sobre a infra-estrutura do cliente ou informações sobre integração de hardware e software necessárias para o software que esta sendo desenvolvido, dessa maneira, na análise o artefato descrição de funcionalidades precisou ser expandido para incluir esses tópicos por causa dos requisitos de negócio específicos.

A especificação se mostrou bastante detalhada, forçando o pesquisador a passar por todos os processos da arquitetura de referência diversas vezes a fim de localizar os impactos dos requisitos de negócio na arquitetura de referência.

$\mathrm{Na}$ etapa de especificação não foi possível identificar alterações nos fluxos de seqüência das atividades, estas só foram percebidas no momento de se modelar os modelos comportamentais. Também na modelagem, só foi necessária a alteração de do diagrama de estado do artefato, os demais diagramas de estados não sofreram alteração.

Os elementos do processo que foram alterados na etapa de especificação foram os papéis, as atividades e os artefatos. Na especificação não foi possível verificar mudanças nos fluxos entre as atividades.

Já na etapa de modelagem todos os elementos sofreram detalhamento (artefatos, papéis, atividades e fluxos)

$\mathrm{Na}$ etapa de projeto somente os artefatos foram detalhados e alguns fluxos são revistos para melhor integração entre os processos. Os outros elementos permaneceram inalterados.

Na Tabela 14, a seguir, são comentadas cada uma das variáveis do experimento. 


\begin{tabular}{|c|c|}
\hline Variáveis do experim & ledidas \\
\hline $\begin{array}{l}\text { Tabela de categorização de } \\
\text { requisitos de negócio da fábrica } \\
\text { por visões }\end{array}$ & $\begin{array}{l}\text { Todos os requisitos puderam ser categorizados nas } \\
\text { visões propostas }\end{array}$ \\
\hline $\begin{array}{l}\text { Matriz de requisitos de negócio } \\
\text { e impacto nos objetos } \\
\text { processos }\end{array}$ & $\begin{array}{l}\text { Foi possível obter o impacto dos requisitos de negócio } \\
\text { nos processos. Conseguiu verificar impactos foram } \\
\text { identificados em quase todos os elementos do processo, } \\
\text { porém impactos nos fluxos de seqüência e mensagens } \\
\text { não foram possíveis verificar. }\end{array}$ \\
\hline a atividade & $\begin{array}{l}\text { As principais alterações nos diagramas descritivo de } \\
\text { atividade foram a inserção de novas tarefas e a } \\
\text { adequação das tarefas para geração dos novos artefatos } \\
\text { de acordo com o requisitos de negócio da empresa. }\end{array}$ \\
\hline dos papéis & $\begin{array}{l}\text { Todos os papéis foram redefinidos, pois na empresa os } \\
\text { papéis têm suas definições diferentes na apontada pela } \\
\text { arquitetura de referência. Os papéis da empresa foram } \\
\text { definidos de acordo com o SCRUM e com os papéis } \\
\text { existentes atualmente. }\end{array}$ \\
\hline Des & $\begin{array}{l}\text { Os artefatos da arquitetura de referência foram } \\
\text { praticamente inalterados, pois a empresa não possuía a } \\
\text { maioria dos processos gerenciais como Gerência de } \\
\text { configuração, gerência da qualidade, gerência de } \\
\text { medidas e análise, monitoramento e controle do projeto. } \\
\text { As maiores mudanças ocorreram onde já se possuía um } \\
\text { artefato definido na empresa, então o artefato continuou } \\
\text { com o mesmo nome agregando o conteúdo apresentado } \\
\text { na arquitetura de referência. }\end{array}$ \\
\hline $\begin{array}{l}\text { Diagrama estrutural } \\
\text { processo e da atividade }\end{array}$ & $\begin{array}{l}\text { Os diagramas foram realizados por último na etapa de } \\
\text { modelagem. Para a análise da instanciação nesta } \\
\text { empresa se mostraram úteis para a organização das } \\
\text { atividades de um processo facilitando a visualização. }\end{array}$ \\
\hline $\begin{array}{l}\text { Diagrama de estados do } \\
\text { processo }\end{array}$ & $\begin{array}{l}\text { Estes diagramas não sofreram alteração durante a } \\
\text { instanciação. São idênticos para todos os processos }\end{array}$ \\
\hline $\begin{array}{l}\text { Diagrama dos estados das } \\
\text { atividades do processo }\end{array}$ & $\begin{array}{l}\text { Estes diagramas não sofreram alteração durante a } \\
\text { instanciação. São idênticos para todos os processos }\end{array}$ \\
\hline
\end{tabular}




\begin{tabular}{|c|c|}
\hline $\begin{array}{l}\text { Diagrama dos estados dos } \\
\text { atores do processo }\end{array}$ & $\begin{array}{l}\text { Estes diagramas não sofreram alteração durante a } \\
\text { instanciação. São idênticos para todos os processos }\end{array}$ \\
\hline $\begin{array}{l}\text { Diagrama dos estados dos } \\
\text { artefatos do processo }\end{array}$ & $\begin{array}{l}\text { O estado "artefato integrado" foi removido do diagrama de } \\
\text { estados da arquitetura de referencia, desta maneira o } \\
\text { diagrama de estados do artefato ficou como na Figura } 31 \text {, } \\
\text { e todos os artefatos possuem o mesmo diagrama de } \\
\text { estados. }\end{array}$ \\
\hline $\begin{array}{l}\text { Diagrama de fluxo de } \\
\text { seqüência e de mensagens } \\
\text { entre atividades }\end{array}$ & $\begin{array}{l}\text { Este diagrama precisou ter a maioria dos nomes de } \\
\text { atividades e artefatos substituídos em relação a } \\
\text { arquitetura de referência para aderência aos modelos } \\
\text { estruturais. A seqüência entre as atividades sofreu } \\
\text { mínimas alterações, até porque não houve remoção de } \\
\text { atividades ou de artefatos. }\end{array}$ \\
\hline Templates dos artefatos & $\begin{array}{l}\text { A arquitetura de referência não possuía os templates dos } \\
\text { documentos, desta maneira, a definição deste templates é } \\
\text { uma característica única, sendo uma das diferenças } \\
\text { entre as arquiteturas de referência e operacional }\end{array}$ \\
\hline Guia de processos & $\begin{array}{l}\text { No guia de processos resultado a primeira diferença que } \\
\text { se nota são os diferentes nomes para os papéis. Em } \\
\text { seguida os nomes dos artefatos e das atividades } \\
\text { adequados a empresa B. }\end{array}$ \\
\hline
\end{tabular}

Tabela 14 - Análise das variáveis da aplicação experimental na empresa A

\subsubsection{Execução na Empresa B}

- Descrição da empresa B

Devido ao termo de confidencialidade assinado entre os pesquisadores e a empresa essa será chamada de empresa B.

A empresa B é uma empresa que desenvolveu um ERP próprio e comercializa para indústrias, principalmente do setor de material escolar e de consumo de escritórios, esse ERP foi desenvolvido com uma ferramenta geradora de código chamada de Genexus, mas a empresa também desenvolve partes do sistema em .NET quando o gerador de código não é eficiente. Além do desenvolvimento, a empresa dá suporte 
aos clientes que já possuem o sistema instalado.

No início dos trabalhos a empresa contava com funcionários 10 . Sendo sete deles da área de desenvolvimento de software e os outros três de áreas administrativas.

Segue o organograma da empresa na Figura 30. Os cargos que estão destacados em cinza são cargos relacionados com o processo de desenvolvimento de software.

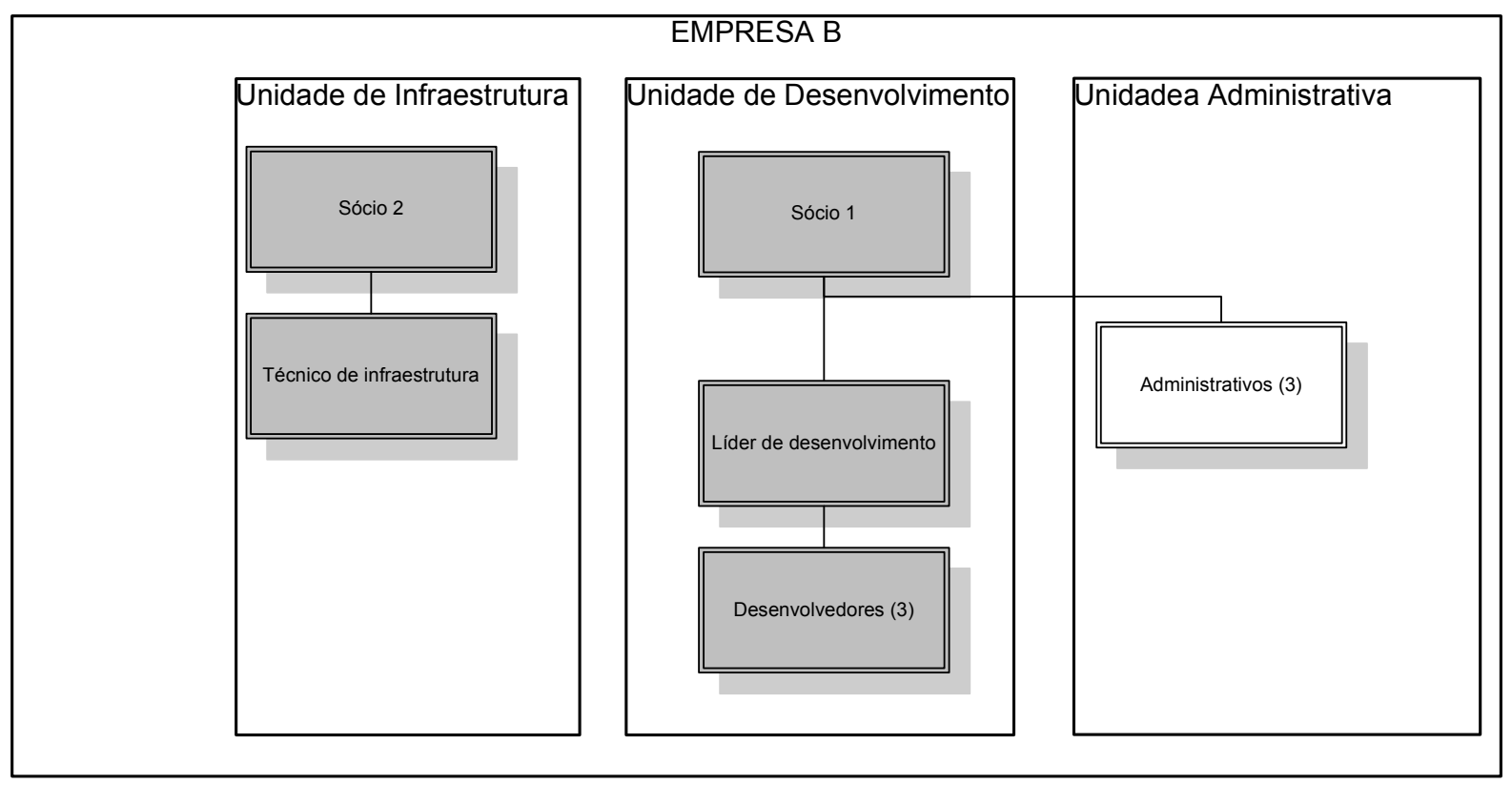

Figura 35 - Organograma da empresa B

Segundo o levantamento realizado com os diretores para aprovação do projeto, a decisão pela aceitação do experimento com a empresa ocorreu por que a empresa tem uma necessidade de formalização das atividades executadas para aumentar o controle e qualidade, pois o retrabalho é excessivo, projetos que deveriam levar 1 mês levam 2 a 3 meses para serem finalizados por completo e tendo reflexo no recebimento dos pagamentos e das mensalidades do suporte ao sistema.

Em cada projeto a unidade administrativa realiza a venda do projeto, o projeto é iniciado pela unidade de desenvolvimento que é suportada pela unidade de infraestrutura.

- Início do experimento 
O experimento iniciou com a apresentação dos pesquisadores e da proposta de parceria para toda a equipe da empresa, apresentado o que seria feito, porque e como cada um deles iria participar do processo.

Após essa apresentação foram realizadas entrevistas com todos os envolvidos nos projetos a partir do questionário.

Com base nas respostas os requisitos de negócio foram descritos, classificados e categorizados. Segue a tabela com os requisitos de negócio da empresa B.

\begin{tabular}{|l|l|}
\hline ID & Descrição dos requisitos de negócio \\
\hline 1 & $\begin{array}{l}\text { Projetos de desenvolvimento de novas funcionalidades e adaptações } \\
\text { ao sistema ERP já existente. }\end{array}$ \\
\hline 2 & $\begin{array}{l}\text { Diminuir os retrabalhos da equipe que são causados pela falta de uma } \\
\text { especificação detalhada. }\end{array}$ \\
\hline 3 & Melhorar a estimativa de prazos, esforço dos projetos \\
\hline 4 & $\begin{array}{l}\text { Existe um papel na empresa de líder de infraestrutura que é exercido } \\
\text { por um dos sócios então a fábrica precisa necessariamente conter as } \\
\text { atividades referentes a esse papel específicas e separadas das } \\
\text { demais. }\end{array}$ \\
\hline 5 & $\begin{array}{l}\text { Aumentar o formalismo no controle de projeto principalmente nas } \\
\text { entregas. Existem problemas na entrega dos projetos, pois o cliente } \\
\text { não aceita que o sistema está terminado, exige uma série de } \\
\text { alterações e não inicia o pagamento da mensalidade de manutenção } \\
\text { do sistema }\end{array}$ \\
\hline 6 & $\begin{array}{l}\text { Manter uma base de dados com as versões dos sistemas implantados } \\
\text { nos clientes, para facilitar a manutenção e o desenvolvimento de novas } \\
\text { funcionalidades }\end{array}$ \\
\hline 7 & $\begin{array}{l}\text { Utilizar a técnica SCRUM } \\
\text { Utilizar o modelo de qualidade CMMI nível 2 }\end{array}$ \\
\hline 8
\end{tabular}

Tabela 15 - Requisitos de negócio da empresa B.

Esses requisitos foram classificados nas seguintes categorias 


\begin{tabular}{|l|l|l|}
\hline \multirow{4}{*}{ Visões } & Categorias & $\begin{array}{l}\text { Candidatos } \\
\text { Requisitos }\end{array}$ \\
\hline \multirow{5}{*}{ Empresa } & Políticas & \\
\cline { 2 - 3 } & Procedimentos & $2,5,7$ \\
\hline & Unidades organizacionais & \\
\hline & Papéis corporativos & \\
\hline & Agencias regulamentadoras & \\
\hline & Stakeholders & \\
\hline & Fornecedores & \\
\hline & Mercado & \\
\hline \multirow{5}{*}{ Engenharia } & $\begin{array}{l}\text { Tipos de } \\
\text { desenvolvidos }\end{array}$ & 1 \\
\hline & Recursos utilizados & \\
\hline & Processos & 3,4 \\
\hline \multirow{5}{*}{ Informação } & Padrões & 8 \\
\hline & Produtos de software & \\
\hline Tecnologia & Tecnologias utilizadas & \\
\hline Computação & Ferramentas & 6 \\
\hline
\end{tabular}

Tabela 16 - Tabela de categorização de requisitos de negócio da fábrica por visões, empresa A.

Como a empresa B já realizava desenvolvimento de software, foi necessário levantar os processos que já existiam na empresa. Então o cruzamento desses processos existentes com a arquitetura de referência foi realizado para os processos da empresa B da mesma maneira que foi feito para a empresa $A$.

A partir desses requisitos realizou a matriz de impactos dos requisitos na arquitetura de processos de referência. 


\begin{tabular}{|c|c|c|c|}
\hline $\begin{array}{c}\text { ID do requisitos de } \\
\text { negócio }\end{array}$ & $\begin{array}{c}\text { Processos da } \\
\text { Arquitetura de } \\
\text { referência } \\
\text { impactados }\end{array}$ & $\begin{array}{c}\text { Elementos do processo } \\
\text { impactados }\end{array}$ & $\begin{array}{l}\text { Ação a ser } \\
\text { executada }\end{array}$ \\
\hline 1 & Desenvolvimento & $\begin{array}{l}\text { Todas as atividades e } \\
\text { artefatos }\end{array}$ & Redefinir \\
\hline \multirow[t]{2}{*}{2} & Desenvolvimento & Atividade: Especificação & Expandir \\
\hline & \begin{tabular}{|l|} 
Monitoramento e \\
controle do \\
projeto
\end{tabular} & Atividade: Revisão & Expandir \\
\hline 3 & Planejamento & Atividade: Estimativa & Reduzir \\
\hline 4 & Desenvolvimento & $\begin{array}{l}\text { Todas as atividades e } \\
\text { artefatos }\end{array}$ & Adicionar \\
\hline \multirow[t]{2}{*}{5} & Desenvolvimento & Atividade: Implantação & \\
\hline & Gerência & $\begin{array}{ll}\text { Artefato: } & \text { Plano } \\
\text { Implantação } & \text { com testes } \\
\text { de aceitação } & \end{array}$ & Expandir \\
\hline \multirow[t]{2}{*}{6} & $\begin{array}{l}\text { Gerenciamento } \\
\text { de configuração }\end{array}$ & Artefato & Adicionar \\
\hline & $\begin{array}{l}\text { Gerenciamento } \\
\text { de requisitos }\end{array}$ & $\begin{array}{l}\text { Atividade: Registro de } \\
\text { mudanças e motivos }\end{array}$ & Expandir \\
\hline \multirow[t]{4}{*}{7} & Desenvolvimento & Artefatos: Especificação & Redefinir \\
\hline & $\begin{array}{l}\text { Planejamento do } \\
\text { projeto. }\end{array}$ & $\begin{array}{l}\text { Atividade: estimativa de } \\
\text { esforço e custo }\end{array}$ & Redefinir \\
\hline & \begin{tabular}{|l} 
Monitoramento \\
controle dos
\end{tabular} & Artefatos: Cronograma & Substituir \\
\hline & projetos & Atividade: Revisão & Substituir \\
\hline 8 & $\begin{array}{lr}\text { Utilizar } & \text { a } \\
\text { arquitetura } & \text { de } \\
\text { referência } & \text { CMMI }\end{array}$ & & \\
\hline
\end{tabular}

Tabela 17 - matriz de impacto da empresa B 
A partir da Tabela 12 foi gerada a especificação detalhada, contendo os processos que seriam idênticos aos da arquitetura de referência e as adequações, e esta foi validada em reunião com todos da empresa $B$.

Após a especificação iniciou-se a etapa de modelagem dos processos. Os modelos também foram validados pela empresa. As figuras 36 e 37 apresentam alguns diagramas gerados.

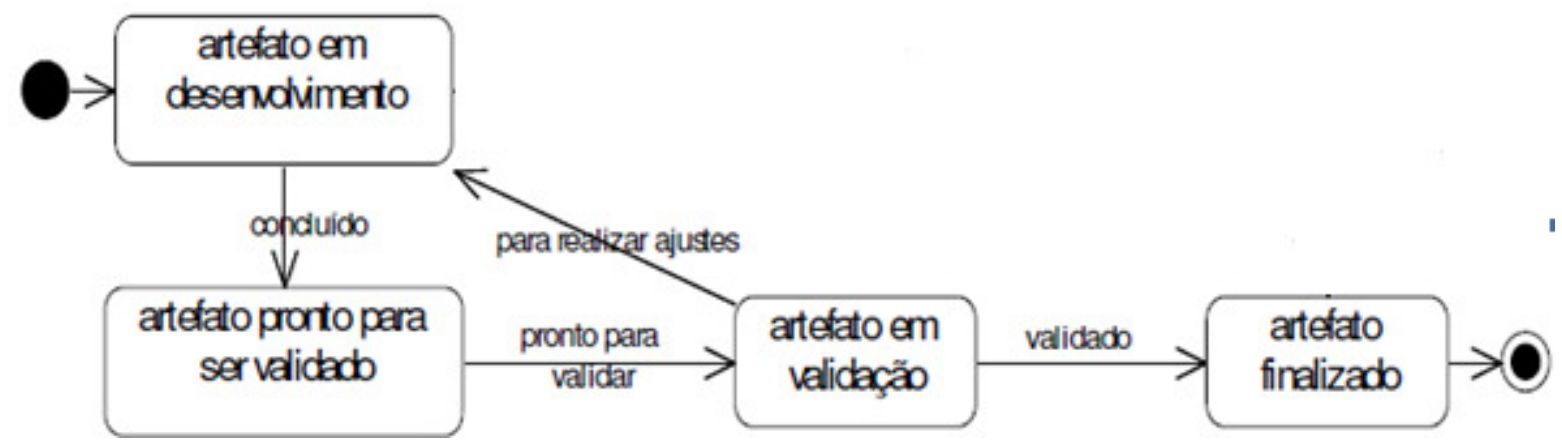

Figura 36 - Diagrama de estados do artefato da empresa B.

\begin{tabular}{|l|}
\hline $\begin{array}{l}\text { Processo de Planejamento do } \\
\text { projeto }\end{array}$ \\
\hline $\begin{array}{l}\text { - Objetivo: Criar o plano de } \\
\text { desenvolvimento do projeto. } \\
\text { - Tipo: Gerencial } \\
\text { - Estado: ativo }\end{array}$ \\
\hline
\end{tabular}

1.1.1 PPP3. Validar Estimativas

- Tipo: operacional

- Descrição: Verificar a aderência entre o tempo estimado, a experiência da equipe, a importância das estórias e o tempo do projeto.

- Meta: 4 horas

-Pré: Estimativas do product backlog criadas.

- Pós: Product Backlog com estimativas validado.

Estado: ativa

- Verificar os prazos estimados.

- Verificar o grau de importância das estórias.

- Verificar aderência entre grau de importância e prazo estimado.

- Reorganizar a seqüência das estórias se for necessário ou solicitar novas estimativas.

Figura 37 - Exemplo de diagrama estrutural do processo e da atividade da empresa B, para o processo de Gestão de acordos com fornecedores. 
Por fim se executou o projeto dos processos com a criação dos templates e do guia de processos.

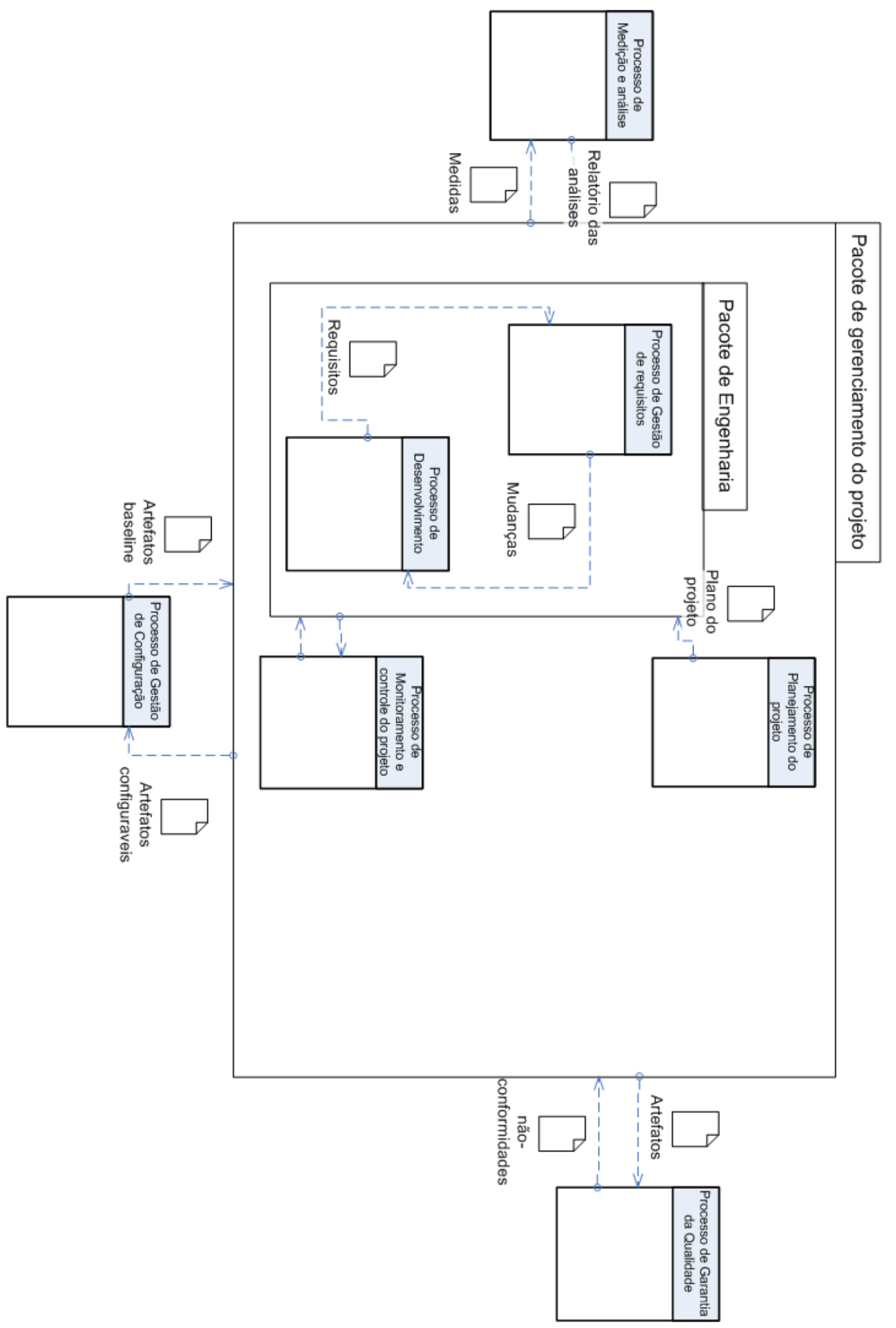

Figura 38 - Imagem do guia de processos da empresa B 


\subsubsection{Análise do experimento $B$}

A análise do experimento foi realizada segundo as variáveis apontadas. Segue a Tabela 18 que apresenta os resultados da análise de cada variável da aplicação experimental na empresa B.

\begin{tabular}{|c|c|}
\hline Variáveis do experimento & Medidas \\
\hline $\begin{array}{l}\text { Tabela de categorização de } \\
\text { requisitos de negócio da fábrica } \\
\text { por visões }\end{array}$ & $\begin{array}{l}\text { Todos os requisitos puderam ser categorizados nas } \\
\text { visões propostas }\end{array}$ \\
\hline $\begin{array}{l}\text { Matriz de requisitos de negócio } \\
\text { e impacto nos objetos } \\
\text { processos }\end{array}$ & $\begin{array}{l}\text { Foi possível obter o impacto dos requisitos de negócio } \\
\text { nos processos. Conseguiu verificar impactos foram } \\
\text { identificados em quase todos os elementos do processo, } \\
\text { impactos nos fluxos de seqüência e mensagens também } \\
\text { foram verificados pois criou-se atividades que não } \\
\text { existiam. }\end{array}$ \\
\hline $\begin{array}{lll}\text { Diagrama } & \text { descritivo } & \mathrm{da} \\
\text { atividade } & & \end{array}$ & $\begin{array}{l}\text { As principais alterações nos diagramas descritivo de } \\
\text { atividade foram a inserção de novas tarefas e a } \\
\text { adequação das tarefas para geração dos novos artefatos } \\
\text { de acordo com o requisitos de negócio da empresa. }\end{array}$ \\
\hline Diagrama descritivo dos papéis & $\begin{array}{l}\text { Todos os papéis foram redefinidos, pois na empresa os } \\
\text { papéis têm suas definições diferentes na apontada pela } \\
\text { arquitetura de referência. Os papéis da empresa foram } \\
\text { definidos de acordo com o SCRUM e com os papéis } \\
\text { existentes atualmente. }\end{array}$ \\
\hline Diagrama descritivo do artefato & $\begin{array}{l}\text { Os artefatos da arquitetura de referência foram } \\
\text { praticamente inalterados, pois a empresa não possuía a } \\
\text { maioria dos processos gerenciais como Gerência de } \\
\text { configuração, gerência da qualidade, gerência de } \\
\text { medidas e análise, monitoramento e controle do projeto. } \\
\text { As maiores mudanças ocorreram onde já se possuía um } \\
\text { artefato definido na empresa, então o artefato continuou } \\
\text { com o mesmo nome agregando o conteúdo apresentado } \\
\text { na arquitetura de referência. }\end{array}$ \\
\hline Diagrama & Os diagramas foram realizados por último na etapa de \\
\hline
\end{tabular}




\begin{tabular}{|c|c|}
\hline processo e da atividade & $\begin{array}{l}\text { modelagem. Para a análise da instanciação nesta } \\
\text { empresa se mostraram úteis para a organização das } \\
\text { atividades de um processo facilitando a visualização. }\end{array}$ \\
\hline $\begin{array}{l}\text { Diagrama de estados do } \\
\text { processo }\end{array}$ & $\begin{array}{l}\text { Estes diagramas não sofreram alteração durante a } \\
\text { instanciação. São idênticos para todos os processos }\end{array}$ \\
\hline $\begin{array}{l}\text { Diagrama dos estados das } \\
\text { atividades do processo }\end{array}$ & $\begin{array}{l}\text { Estes diagramas não sofreram alteração durante a } \\
\text { instanciação. São idênticos para todos os processos }\end{array}$ \\
\hline $\begin{array}{l}\text { Diagrama dos estados dos } \\
\text { atores do processo }\end{array}$ & $\begin{array}{l}\text { Estes diagramas não sofreram alteração durante a } \\
\text { instanciação. São idênticos para todos os processos }\end{array}$ \\
\hline $\begin{array}{l}\text { Diagrama dos estados dos } \\
\text { artefatos do processo }\end{array}$ & $\begin{array}{l}\text { O estado "artefato integrado" foi removido do diagrama de } \\
\text { estados da arquitetura de referencia, desta maneira o } \\
\text { diagrama de estados do artefato ficou como na Figura } 31 \text {, } \\
\text { e todos os artefatos possuem o mesmo diagrama de } \\
\text { estados. }\end{array}$ \\
\hline $\begin{array}{l}\text { Diagrama de } \text { fluxo de } \\
\text { seqüência e de } \\
\text { entre atividades }\end{array}$ & $\begin{array}{l}\text { Este diagrama precisou ter a maioria dos nomes de } \\
\text { atividades e artefatos substituídos em relação a } \\
\text { arquitetura de referência para aderência aos modelos } \\
\text { estruturais. A seqüência entre as atividades sofreu } \\
\text { mínimas alterações, até porque não houve remoção de } \\
\text { atividades ou de artefatos. }\end{array}$ \\
\hline Ten & $\begin{array}{l}\text { A arquitetura de referência não possuía os templates dos } \\
\text { documentos, desta maneira, a definição deste templates é } \\
\text { uma característica única, sendo uma das diferenças } \\
\text { entre as arquiteturas de referência e operacional }\end{array}$ \\
\hline Guia & $\begin{array}{l}\text { No guia de processos resultado a primeira diferença que } \\
\text { se nota são os diferentes nomes para os papéis. Em } \\
\text { seguida os nomes dos artefatos e das atividades } \\
\text { adequados a empresa B. }\end{array}$ \\
\hline
\end{tabular}

Tabela 18 - Análise das variáveis da aplicação experimental na empresa B

\subsubsection{Interpretação dos experimentos}

Neste item serão interpretados os dados dos dois experimentos com a finalidade de se encontrar alguma evidência que possa ser extrapolada para os outros experimentos que venham a ser feitos com o método de instanciação. 


\subsubsection{Interpretação do contexto}

Em relação à aplicação do método nos dois experimentos foi possível observar que o método de instanciação pode ser utilizado por inteiro. Todas as etapas foram executadas e todos os subprodutos do método foram criados.

Os requisitos de negócio juntamente com a arquitetura de referência formaram as matérias-primas do método para a criação dos processos instanciados. Nos dois experimentos todos os elementos do processo, em pelo menos um dos processos, precisaram ser adequados a algum dos requisitos de negócio comprovando assim a necessidade da instanciação.

Considerando o impacto dos requisitos de negócio na instanciação pode ser observado que o requisito de negócio número 5 é igual para as duas empresas e também gerou as mesmas adequações aos objetos processos. Isso mostrou uma consistência do método nestas aplicações, mas mais experimentos são necessários para que se remova a dúvida de que esse resultado tenha sido devido ao mesmo pesquisador ter realizado ambos os experimentos.

Nos dois experimentos as diferenças entre os papéis da empresa em relação a arquitetura de referência causaram grandes alterações nos fluxos das atividades como ocorrido na empresa B.

A seguir está a figura do processo de desenvolvimento da arquitetura de referência, apresentado como era o processo de desenvolvimento que serviu de modelo para a instanciação. Após a instanciação foi necessário adicionar novas atividades do processo, para adequar ao requisito de negócio da empresa. Estão destacadas em cinza na Figura 40 as atividades que foram adicionadas devido ao requisito de negócio $n^{\circ} 4$ da empresa $B$. 


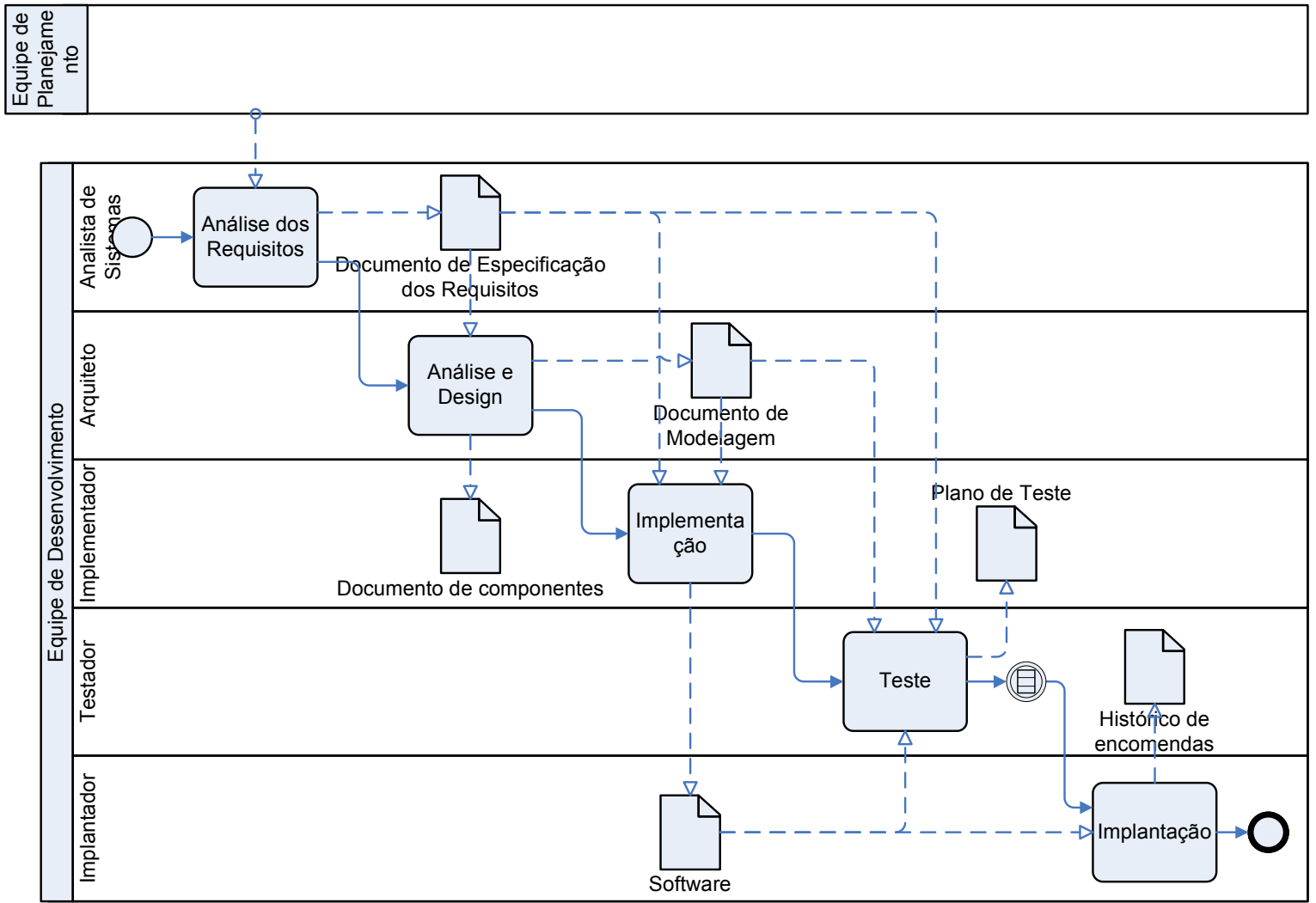

Figura 39 - Diagrama de fluxo de seqüência e mensagens do processo de desenvolvimento da arquitetura de referência

Processo de Desenvolvimento

$$
(\mathrm{PD})
$$
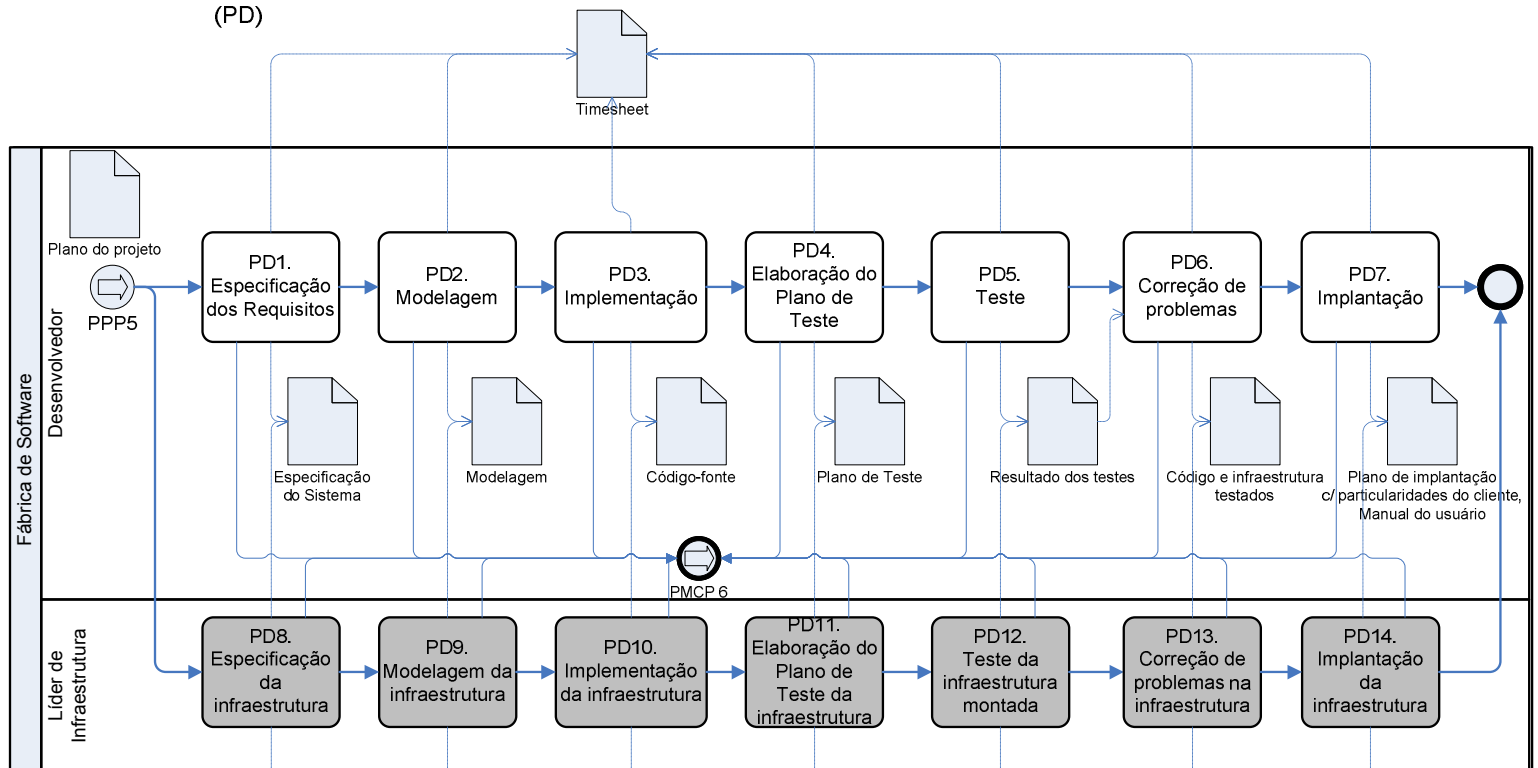

Figura 40 - Diagrama de fluxo de seqüência e mensagens do processo de desenvolvimento instanciado para empresa B 


\section{CONSIDERAÇÕES FINAIS}

Neste capítulo serão abordadas as conclusões obtidas após a execução deste trabalho bem como trabalhos futuros que poderão ser realizados a partir desta pesquisa.

\subsection{CONCLUSÕES}

Primeiramente foi importante constatar que a metodologia de pesquisa do quadrante de Pasteur se mostrou alinhada aos objetivos das pesquisas de engenharia de software experimental, buscando a comprovação na prática dos conceitos e ao mesmo tempo aumentando o entendimento sobre a instanciação

A definição teórica do fenômeno da instanciação em objetos processos trouxe ainda mais relevância para a teoria dos objetos processos proposta pelo grupo do LTS no que diz respeito a fábrica de software. A relevância foi dada tanto no aspecto conceitual com o aumento do entendimento sobre o domínio dos objetos processos como também no aspecto prático, observando-se a utilização dos objetos processos em situações reais e as diversas formas instanciadas que estes podem assumir.

A aplicação prática mostrou sua relevância pela oportunidade de entender as necessidades de empresas de software em relação aos processos de desenvolvimento de software e como a instanciação de processos faz parte de uma da criação de processos aderentes a um modelo de qualidade e principalmente dos requisitos de negócio. Mesmo assim, ainda são necessários mais experimentos para se validar o método e entender quais tipos de requisitos provocam a necessidade de instanciação de processos de uma arquitetura de referência.

Ficou evidente que o planejamento apresentado pelo método é geral, porém, a operação de cada etapa deve ser específica para cada processo que está sendo instanciado, ou seja, deve-se entender dos detalhes técnicos de cada processo que está se instanciando. 
Como conclusão do experimento com empresas reais é importante ressaltar que os questionários são guias para o levantamento, necessitando também da liderança do entrevistador durante a entrevista para direcionar o entrevistado a passar por todos os pontos de interesse, pois muitas vezes a nomenclatura utilizada no questionário difere da nomenclatura utilizada no dia-a-dia da empresa e isso pode alterar o resultado.

Baseado nos resultados, para a aplicação do método de instanciação em instanciação tipo II, é interessante que sejam removidos alguns dos modelos que são desnecessários para esta instanciação como o modelo de estados do processo, da atividade, do artefato e do papel, pois não sofreram alteração para montar a arquitetura operacional da fábrica de software e não sofreram mudanças na arquitetura do projeto.

Não foram analisados e nem previstos os impactos dos artefatos gerados pelo método na dinâmica da empresa e isso ficou evidente na empresa $A$, pois com a especificação dos novos processos em mão o diretor percebeu que a atual equipe não conseguiria atingir a maturidade no tempo que ele desejava e decidiu mudar a equipe.

A importância de se instanciar os processos de uma maneira sistemática foi para garantir uma maneira para se gerar processos flexíveis que se adaptam a qualquer técnica e procedimento. O projeto de uma fábrica de software deve ser altamente flexível para se adaptar a qualquer técnica e procedimento de gestão e desenvolvimento.

\subsection{TRABALHOS FUTUROS}

A partir deste trabalho podem ser realizados os seguintes trabalhos futuros:

- Aplicação prática em diversas empresas da instanciação tipo II. Assim será possível avaliar quais são as verdadeiras dificuldades encontradas pelas empresas nas instanciações dos processos para os projetos. 
- Estudar uma técnica de reuso das arquiteturas instanciadas, desta maneira poderia se criar uma base com os modelos, artefatos, papéis e a reutilização dessas instanciações pouparia tempo para implantação de fábricas de software.

- Neste trabalho precisou-se adequar a técnica SCRUM à arquitetura de processos, mas isso foi feito sem se seguir um procedimento definido. Uma pesquisa que busque criar um procedimento específico e conceitual para se inserir técnicas de engenharia de software em arquitetura de processos a partir dos elementos dos processos seria um tema relevante para a pesquisa aumentando o detalhamento do método de instanciação. 


\section{BIBLIOGRAFIA}

AAEN, I., BØTCHER, P. AND MATHIASSEN L. Software Factory: Contributions and Illusions. In: Twentieth Information Systems Research Seminar in Scandinavia, Oslo, 1997.

AUGUSTO, A., SANT'ANNA, N. KEINBAUM, G. Uma Visão Geral sobre a da Qualidade de Software. Workshop dos Cursos de Computação Aplicada do INPE, 5 (WORCAP), 2005.

BASILI, V. Key note speaker. The Role of Empirical Study in Software Engineering Proceedings of the 30th Annual IEEE/NASA Software Engineering Workshop SEW30 (SEW'06). 2006

BASILI, V.; LANUBILE, F. Building knowledge through families of experimentes. In: IEEE Transactions on Software Engineering, Vol.25, N4, July/August, IEEE PRESS, 1999, p.456-473

BASILI, V. SELBY, R. HUTCHENS, D. Experimentation in Software Engineering. IEEE Transaction on Software Engineering. Vol. SE-12, n`7, July 1986 p. 733 -743

BECERRA, J. R. SIQUEIRA, F. BARBARÁN, G. M. C. A Software Factory for Education. 2008. (Apresentação de Trabalho/Congresso).

BORSOI, B. Arquitetura de processo aplicada na integração de fábricas de software. Tese (doutorado em engenharia elétrica) - Universidade de São Paulo. Orientador: Jorge Luis Risco Becerra, 2008, 177 p.

BUDLONG,F. SZULEWSKI, P. GANSKA, R. Process Tailoring for Software Project Plans, $\quad$ http://www.stsc.hill.af.mil/resources/tech docs/process plan/prplp104.html Software Technology Support Center U.S. Air Force. January 1996.

CANTONE G. Software Factory: Modeling the Improvement. IEEE 1992. p.124-129. 
CRUZES, D. Análise Secundária de Estudos Experimentais em Engenharia de Software. Tese de Doutorado.Faculdade de Engenharia Elétrica e de Computação UNICAMP. Campinas, 2007.

CURTIS, B. Measurement and Experimentation in Software Engineering. Procedings of the IEEE, VOL. 68, n 9 . Setember 1980.

CUSUMANO, M. The Software Factory: A Historical Interpretation. IEEE March 1989. P. $23-30$.

FERNSTROM, C. NARFELT, K. OHLSSON, L. Software Factory Principles, Architecture, and Experiments. IEEE Software 1992. p. 36-44.

FREIMUT, B.; PUNTER, T.; BIFFL, S.; CIOLKOWSKI, M. State-of-the-art in empirical studies. Virtuelles Software Engineering Kompetenzzentrum, 31/03/2002

GINSBERG, M. QUINN, L. Process tailoring and the software Capability Maturity Model. Technical report, Software Engineering Institute (SEI), 1995.

IBARGÜENGOITIA ,G. SÁNCHEZ, M. RAMÍREZ M. A Procedure for Customizing a Software Process. Proceedings of the Fourth Mexican International Conference on Computer Science (ENC'03). 2003 IEEE.

LI, C. LI, H. LI, M. A Software Factory Model Based on ISO9000 and CMM for Chinese Small Organizations. 2001 IEEE.

MCT 2009 http://www.mct.gov.br/index.php/content/view/77790.html . Acessado em 29/05/2009.

MCT/SEPIN/DIA, 2006 Qualificação CMM e CMMI no Brasil http://www.mct.gov.br/upd_blob/0009/9238.pdf. Acessado em 29/05/2009

KROEGER, T. JACOBS, D. MARLIN, C. Implementing Process Enactment within a 
Process-Centred Software Development Environment. IEEE.

PANIGASSI, R. Método para definição e modelagem de processos de fábrica de software usando RM-ODP e BPM. Dissertação (mestrado em Engenharia Elétrica) Universidade de São Paulo. Orientador: Jorge Luis Risco Becerra, 2007, 158 p.

PEDREIRA, O. PIATTINI, M. LUACES, M. BRISABOA, N. A Systematic Review of Software Process Tailoring. In: ACM SigSoft Software Engineering Notes, May 2007. Volume 32 Number 3.

PERRY, D. Policy and Product-Directed Process Instantiation. 6th International Software Process Workshop Support for the Software Process. IEEE 1991

PINO F. GARCÍA, F. PIANTTINI, M. Software Process improvement in small and médium software enterprises: a systematic review. In: Springer Science+Business Media, LLC 2007, 21 November 2007.

PRESSMAN, R. S. Engenharia de software. 5a ed. Rio Janeiro: McGraw-Hill, 2002, $843 \mathrm{p}$.

RECCO, C. CATARIN, C. BANDOUK, G. site de internet - História Net. A nossa história. Acessado em agosto de 2009. http://www.historianet.com.br/conteudo/default.aspx?codigo=30

RILEY, JOHN D. An Object-Oriented Approach to Software Process Modeling and Definition. Association for Computing Machinery, 1995

RM-ODP. Reference Model of Open Distributed Processing. ISO/IEC 10746-1 | ITUT Rec. X.901. 1996

RM-ODP. Reference Model of Open Distributed Processing. ISO/IEC 10746-2 | ITUT Rec. X.902. 1996

RM-ODP. Reference Model of Open Distributed Processing. ISO/IEC 10746-3 | ITU- 
T Rec. X.903. 1996

RM-ODP. Reference Model of Open Distributed Processing. ISO/IEC 10746-4 | ITUT Rec. X.904. 1996

ROCKWELL, R. GERA, M. The Eureka Software Factory CoRe: A Conceptual Reference Model for Software Factories. IEEE 1993.

SHAFFER, D. SQUIRE, K. The Pasteurization of Education. International Conference of the Learning Sciences. 2006 P.688-694.

SOFTEX 2009. MPS.BR - Melhoria de Processo do Software Brasileiro. http://www.softex.br/mpsBr/ guias/guias/MPS.BR Guia Geral 2009.pdf. Acessado em setembro de 2009.

STOKES, DONALD. Pasteur's Quadrant. Basic Science and Technological Innovation. Brookings Institution Press. 1997.

SUGIYAMA, Y. HORWITZ, E. Building your own software development environment. Software Engineering Journal. Setembro 1991

TRAVASSOS, G. GUROV, D. AMARAL, E. Introdução a Engenharia de Software Experimental. Relatório Técnico. Programa de Engenharia de Sistemas e Computação. COPPE / UFRJ. Rio de Janeiro 2002.

WHITE, S. A. Business process management notation, version 1.0, 3 maio 2004a, 296 p.

WHITE S. A. Process modeling notations and workflow patterns. BPTrends, IBM Corp., mar. 2004b, p. 1-25.

XU, P., RAMESH, B. Using Process Tailoring to Manage Software Development Challenges. IEEE Computer Society. IT Pro. 2008 p.39 